Cover: Artlattc Impresston of Plant Research

by Ludo Van Rompuy 


\section{DISCLAIMER}

This report was prepared as an account of work sponsored by an agency of the United States Government. Neither the United States Government nor any agency Thereot, nor any of their employees, makes any warranty, express or implied, or assumes any legal liability or responsibility for the accuracy, completeness, or usefulness of any information, apparatus, product, or process disclosed, or represents that its use would not infringe privately owned rights. Reference herein to any specific commercial product, process, or service by trade name, trademark, manufacturer, or otherwise does not necessarily constitute or imply its endorsement, recommendation, or favoring by the United States Government or any agency thereof. The views and opinions of authors expressed herein do not necessarlly state or reflect those of the United States Government or any agency thereof. 


\section{DISCLAIMER}

Portions of this document may be illegible in electronic image products. Images are produced from the best available original document. 


\title{
PLANT 'RESEARCH'75
}

\author{
Report of the \\ YICHIGAN STATE JNIVRRSITY/ERERG RESEARCH \\ AND DEVBLOPKENT ADMINISTRATION \\ PLANT RRSEARCH IABORATORY
}

at te

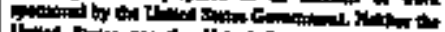

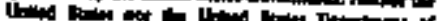
B.

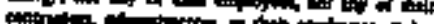

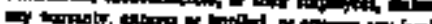

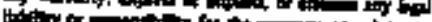

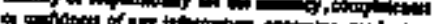

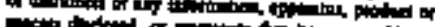

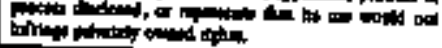

for the Year 1975

MSU/ERDA Plant Research Laboratory

Kuchigan State Univargity

East Lansing, KichIgan 48824, USA 


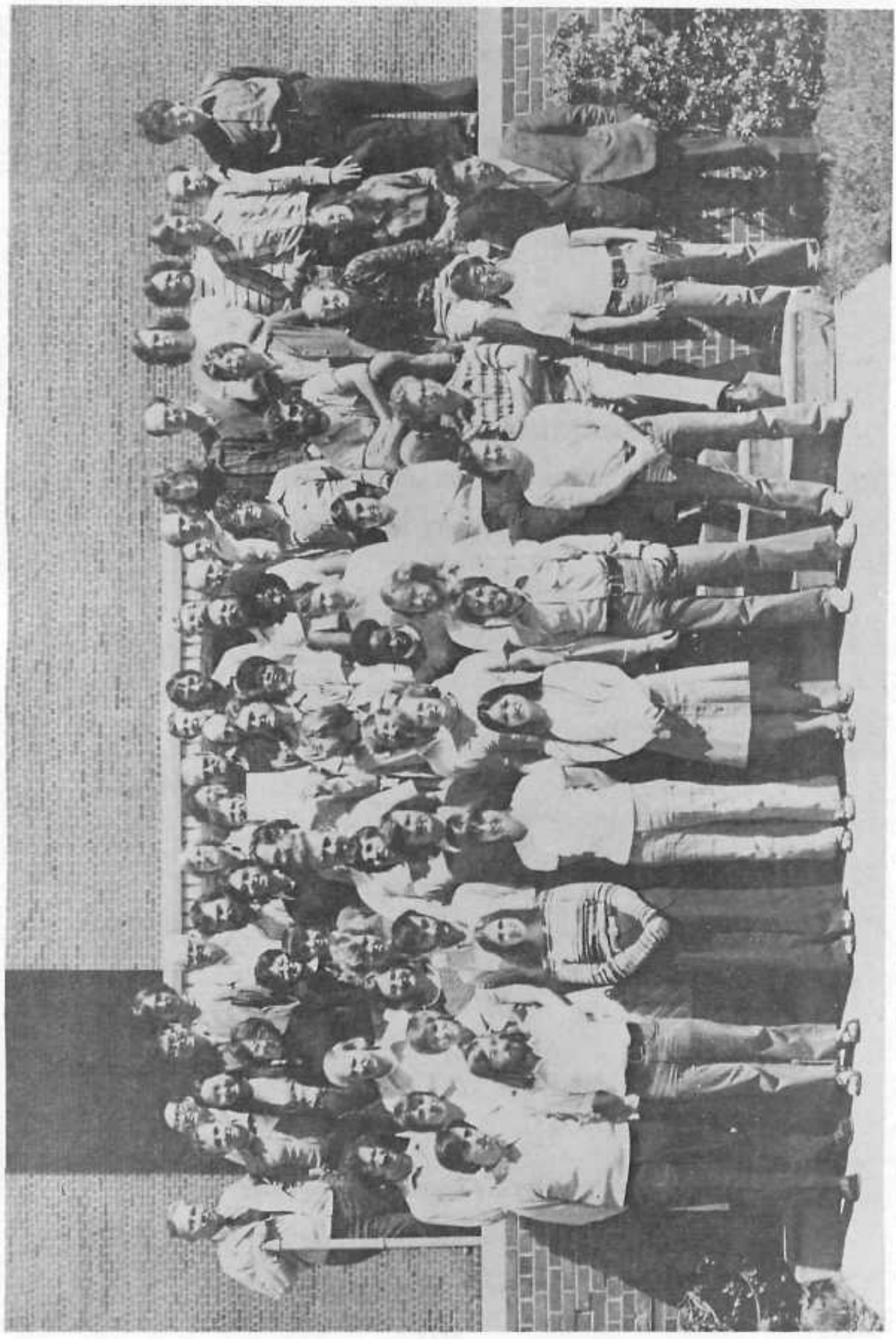



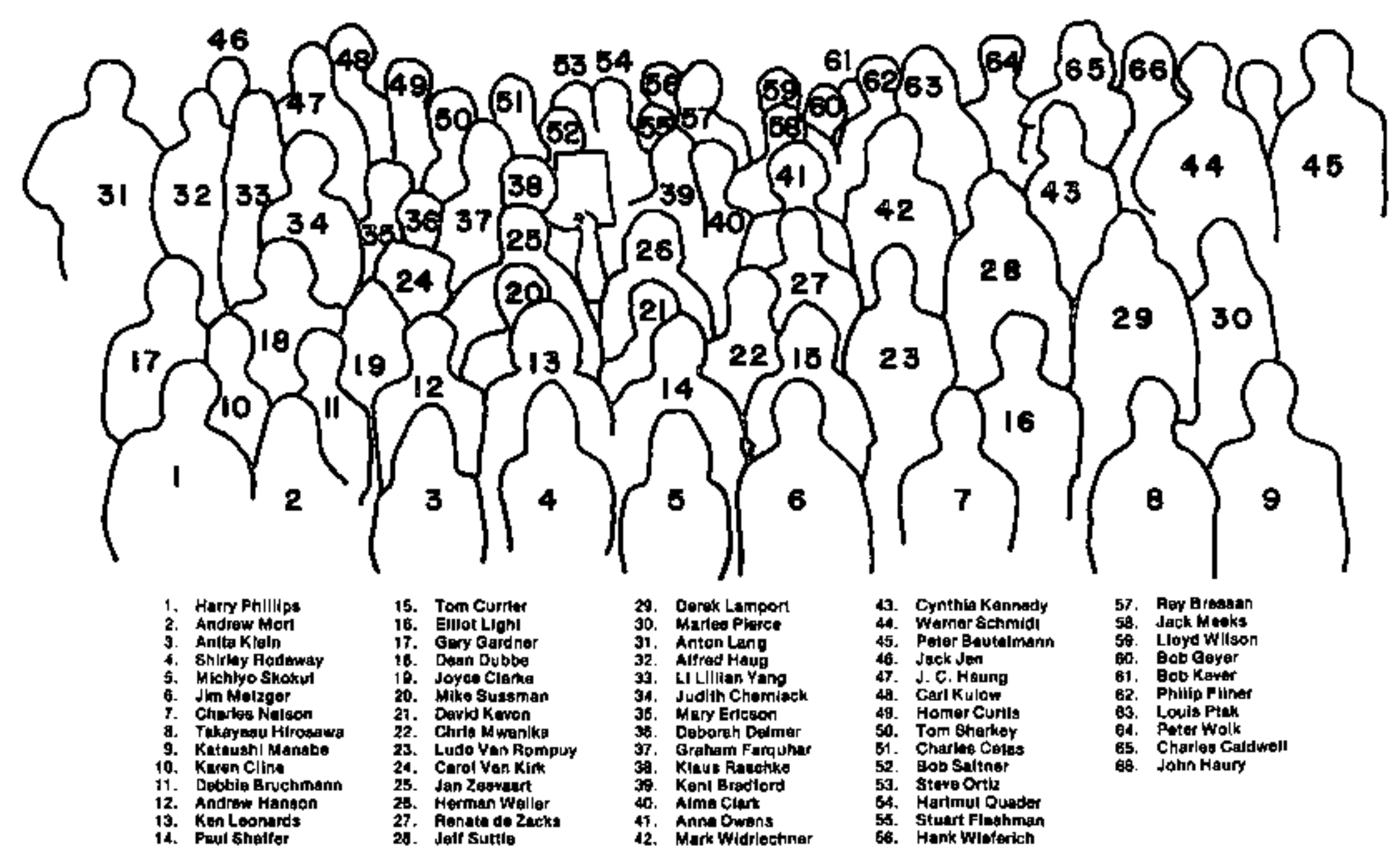

15. Tom Currer

16. Elllot LIghI

17. Gery Gard ner

18. Doun Dubse

19. Joyce Clante

20. Miko Sussman

27. Dawlo Kewon

22. Chria Mwenlkg

23. Ludo Van Rompuy

25. Jan Z gowart

27. Nerman Woller

24. Jaif Suttio

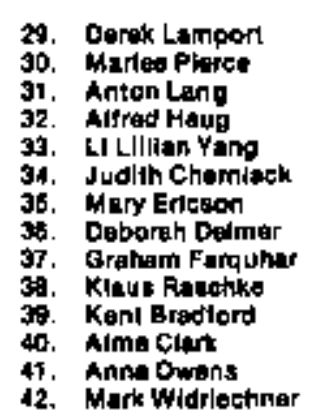

43. Cynthia Kennady

44. Wemar sehmidi

45. Peter Bautelmann

46. Jack Jen

47. J. C. Houng

49. Cerl Kulow

49. Homer Curils

o. Tom Bherker

1. Charke Cales

2. Bob Saltnet

53. Starbortiz

64. Marimul Quader

55. Studrt Fledhman

57. Rey Breasan

58. Jack Mokss

st. Lloyd Wilson

6n. Bob Geyer

61. Bob Karer

62. Philip Finner

3. Louis Ptan

65. Charles Galdwe

65. Charleg Galdwe

14. Peul shaifer

42. Mark Widrlecthner 
CONTKNTS

Director' Report....................... 1

Personnel ........................ 12

Publications ........................ 16

Staff Actfvitles . . . . . . . . . . . . . . 19

PRL Sentnar Sertea ................... 23

Research Reports . . . . . . . . . . . . . . . 27

Stomatal Regulation of the Gas Exchange Between Plant and

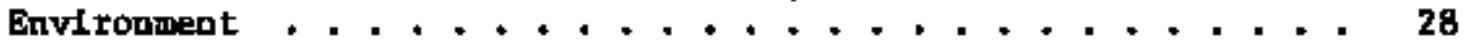

1. Computer Control of Afr-Condittoning and Gas

Analys1s system ................. 28

2. Quantitative Framework for the Study of the Bffects

of Strese on Feedbsck Loopa Involving Stomata . . . . . 29

3. Neasurement of $\mathrm{CO}_{2}$ Loop Gains and the Bffects of Abscistc Actd on these Gatng . . . . . . . . . . 32

4. Control of Stomatal Aperture in Leaves by Absciale Ac1d (ABA): Dependence on Transplration Rate, Presentation T1me, and Temperature ........ . . . . . . 34

5. Synthesia and Metabollam of Malate in Eptodermal Tisgute ....................... . 36

(a) Asgimilation of $\mathrm{CO}_{2}$ by Epidermeg . . . . . . 36

(b) Metaboliam of Malate-ur- ${ }^{14} \mathrm{C}$ and Malate-4- ${ }^{14} \mathrm{C}$ by Epldermal Tigeve . . . . . . . . . . . . . 38

6. Lptake and Metobolism by Epldermal THssue of Radłoactively Labeled Carbohydrates......... 40

Inhibitory Effects in Flower Formation . . . . . . . . . . . . 43

Environmental Control of Plant Growth and Developuent

Throtgh Hormones . . . . . . . . . . . . . . . . . 46

1. Analysis of the Eatrogea-like Praction in Higher Plants.................... 47

2. Floral Induction and Translocation of Labeled Assimilates in Part1ally Induced Kanthiom Leaves . . . 50

3. FIower Formatton and Stem Growth in Two Strafns

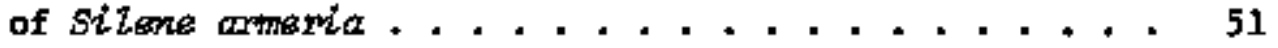

4. The Role of Gibberellin $A_{20}$ and 1ts Metabaliteg in Stem Growth and Flower Formation in Bryophyzlim daigremontianum .....................

5. Siter of Abscisic Acid Synthesis and Metabolism in Ficinus commuis ................... 
Studies on Hormone Act1on................... 56

1. Regulation of Seneacence by Ethylens in

Flower Tissue ....................

(a) Relattonship between Ethylene Erolution and Aging in koming Glory Flower Tisave . . . . . . 56

(b) Ethylene Blosynthesis and Methionine Ketabolism In Senescent Flower Tisaue of Morning Glory . . . . 57

(c) Blosynthesis of Strese-Induced Bthylene in Imisature Morning Glory Flower TIgsue . . . . . . 60

(d) Senescence and Phospholipid Content of Kembraneg of Horning Glory Flower Tlssue . . . . . . . .

(e) Senescence of Flower T1ssue of Tradseocontia hireuticautis . . . . . . . . . . . . . 64

2. Hormone Binding fn Plants . . . . . . . . . . 65

(a) Cytokinin Btnding to a Menbranous Fraction from Cultured Tobacco Cells . . . . . . . . . .

(b) Binding of Cytokinins to Particulate Fractiong from Koss Protopenata . . . , . . . . . . . .

(c) In vivo Binding of 3 H-Banzyladentine in Moss Protonemata . . . . . . . . . . . . . .

3. Effects of 5-Fluorouracil on BNA and $\alpha$-Amylase Syntheefs 17 Barley Aleurone . . . . . . . . . , . . . . . .

Development and Hitrogen Fixation in Filamentous Blue-Green Algae

1. A Substance Stimulating the Differentiation of Spores In the Blue-Green Alga Cylindrosperman Ziahemiforme .

2. Products of the Firation of ditrogen Gas by Filaments and Heterocys te................. 76

3. Envelope Polysaccharides of Heterocysts and Spores ... 79

The PrImary CelI Wall GIycoprotefn Bxtenein and Related

1. Extensin structure .................. . 82

(a) Solubildzation of Extemsin via B-Eltmination Under Semi-hqueoug Condittong . . . . . . . . .

(b) Solubilization of Extensin via Sodicm Chlorite Oxidation ....................

(c) Fractionation of Sodiun Chlorite Solubilized Glycopeptider . . . . . . . . . . . . . .

(d) B-Elimination of Selected Practions Obtained by Sodfum Chlorite Oxidation of Tomato Cell Nalls . .

2. Soluble Hydroxyproline-Rich clycoproteine fron Highey Plantg 
3. Hydroxyproline-Rich Glycopratelns from Volvox..... .

4. Characterization of Possible Extensin Precursars fron Sycamore-Maple Cells . . . . . . . . . . , 68

5. The Uee of Hydrogen Fluortde for Deglycosylation of Glycoproteins and for Sugar Analysls . . . . . . . 88

(a) Glycoprotetn Deglycosylation . . . . . . . . B8

(b) Total Sugar Analysia... . . . . . . . . . 90

Enzyntc Mechantsme and Control of Polyseccharide and Glycoprotein Synthesis in Higher Planta; Celi WaII Structure . . . . . . . . 92

1. Studies on Cellulore Syntheris . . . . . . . . . . 94

(a) The in vivo Rate of Calluloes Depostion During Fiber Development . . . . . . . . . . . . 94

(b) The Effect of Cotmarin on the Synthesis of Prinary and Secondary Wall Celluloes in Developing Cotton Flbers........... 96

(c) Properties of a UDP-glucose: Glucan Syathetase in Cotton Mibere ................ 96

(d) Celluloge Synthesis in Pea Stem Sẹctfons..... 99

(e) The Mon-Celluloste Glucan of Fiber Cell Walla . . 99

2. Biochentcal characterization of the cotton Fiber Cell Wall During Development: The Elongating Fiber Cell Wall Is a Dynamic Structure . . . . . . . . . . . . 100

3. Glycoprotein Synthesis in Developing Cotyledors of Phoseotus vilgaris... . . . . . . . . . . . . 103

Molecular Studies of Membrame Systems . . . . . . . . . . 106

1. Membrane Potential of Thermoplaema actiophila . . . . 106

2. Thermotropic Hesomorphism and Membrane Liplda in the Merb rane of themoptabma aldophita . . . . . . . 107

3. Physico-Biochewical Properties of Developing Zoospores fron Btastoctadielta emsrsonii .......... 108

4. Mtcrosecond Delayed Light Emigeton and Ion Accumulation In Spinach Chloroplasts . . . . . . . . . . . 108

Sensory Transduction ín Plants . . . . . . . . . . . . . . 110

I. Photogensory transduction . . . . . . . . . . . . 111

(a) Photoreductble Cytochrome $b$ of Dictyostelivm . . 111

(b) Uight-induced Absorbance Changes in Corn Coleoptiles . . . . . . . . . . . . . . 113

(c) Inhibition of Phototroptc Responees of Corm Coleoptilea ................... 114

(d) Plasma membrane-bound Cytochrome $b$ and Flavin In Phycomycer . . . . . . . . . . . . . 216 
(e) IIght-Induced Changer in Adenylate Levels In Netroepora crasea and Dictyostetitum dícooiderm ................. 119

2. Thermosensory Transduction: Thermotaxis by Psetudoplasmodia of Dictyostetivom discoiden . . . . . . 120

Regulation of Fornation of Protein Complexes and Enzymes In Higher Plant Cells . . . . . . . . . . . . . . . . . . 123

1. Microtubules and Tubulin . . . . . . . . . . . 123

(a) Interactione of Tobacco cell components with Polymerizing Brain Tubutin . . . . . . . . . 123

(b) Characterization of the Reaction between TubulinColchleine Couplex and Kterotubules. . . . . . . 124

(c) Mechanian of Resietence of Colchioun to colchicine, an Alkaloid whlch It Synthesizes . . . . . . . .

(d) Preparation of $125_{\mathrm{I}}$ Lebeled Tubulin ........ 125

2. Regulation of Nitrogen and Stlfur Aseintlation in Plants . . . . . . . . . . . . . . . . . 126

(a) Urea and Ammonia Assimilation it Tobacco Cells , . 126

(b) Selection of Mutants of the Sulfur and Nitrogen Fathways in the Plant Kingdom . . . . . . . . . . 127

Hechantam of Sulfur Dtoxide Toxicity in Plants . . . . . . 12B 
DIRECTOR'S REPORT

The Regearch Program

$\mathbf{I}$

As explained in the Acting Director's Report in last year's "Plant Resesch", several changes were dectded upan in the research program of the PRL. Two of the existing projects or "tasks" were to be expanded and two nes ones to be inftiated; two exlating tasks were to be terminated. The inmediate reagon for these decfatons was the trangition of our fundting from the U.S. Atomle Rnergy Commission (AEC) to the new U.S. Energy Research and Development Adminiatration (ERDA). The PRI program should reflect the new, broader-based agency's expanded objectives and needs, it should lnclude both resaarch on plants as converters and as users of energy, and research on effects on plantg--crop and other--of environmental atresses that may be caused by expanded energy production, whether deriving from growing reliance on new energy technologies, or the Increased use of old ones, e.g. the growing consuption of coal which is projected well 1nto the 21st century. In the pertod covered by the present report, those decistons bave been Implemented, and it is only approprlate to devote the Director's pages to the activities of the expanded and the newly initiated tasks. However, sone of these activitles did not get under way unt1l late in the reporting periad and are not yet reflected in the section on individual regearch reports. We wtll therefore to some extent antfcipate next year's repart, including certaln results and developments which were not accomplished before 1976 .

II

Our report may begin by stating, as 18 sometines necessary, a triviality. Plants convert solar radiation fnto chemical energy; man uses this atored energy as food, flber and fuel. The conversion of solar energy by plants 1nvolves the sbsorption and reduction of $\mathrm{CO}_{2}$. The Inescapable consequence of the uptake of $\mathrm{CO}_{2}$ by land planta is lose of vater to the atmosphere. Plants moderate thio water loss through the 
action of the stomata-adjustable microscopfc pores present on the surface of leaves and other, younger parts of the plant-but this action aloo reduces the supply of $\mathrm{CO}_{2}$. The stomatal apparatus is the plant's prime and apecific site of control for the regulation of the exchange of water vapor and $\mathrm{CO}_{2}$ between the plant and its aerial exviroment. Stomatal functioning affects the efficiency by wich plants uge sunlight, atmospherte $\mathrm{CO}_{2}$, water and, Indirectly, nutrients found in the soll or supplied as fertilizer. Knowledge of stonatal functioning ts necessary for an estimation of the minfmal water requirement for plant production and for an assessment of the potential of plants as energy converters for man.

The question of how stonata regulate gas exchange is the subject of PRL Tagi 111 , headed by $\mathrm{K}$. Raschke. In the reporting periad, three approaches to obtalning answers were wade: (1) A theoretical franework was built (by G. D. Farquhar) in which the notion of environmental gatn was applied to the treatment of stomatal feadback tn the steady state as well ss during transients. Conversion of these expressions to state space vartable notation allows applicstion of optinal coctrol theory, lacluding the 1nverse of optimal control, -1.e, what index of performance is being mintmized by atamatal action? (11) The existing computer-controlled air-conditioning and gas analygla sygtem was uged to meagure gaing in the stomatal feedback loop involving $\mathrm{CO}_{2}$ in the absence and presence of abscistc actd, the phytohorwone which is formed in the lesves under water stress and which may cauge stonatal closure. The equipment was modified and programs were written enabling us to perturb the leaf's environaent In such a fashion that the effect of stomatal movement on one kind of gas exchange (e.g. that of $\mathrm{CO}_{2}$ ) is continuougly belng compengated while the feedback loop tnvolving the other gas exchange (e.g. that of $\mathrm{H}_{2} 0$ ) renains fully functional. (i1i) The osmotie mechanism of the stomatal valve which controls these gag exchanges was further anatyzed during Raschke's sabbatical leave in Wunich, Germany, where he Investigated, with P. Dittrich of the University of Munich, the metabolism of malate and carbohydrates in leaf epidermes. We hope that the results of these studies will lead to elucidation of the mechantsn by wich guard cells respond to the feedback messenger 
to the stomata, $\infty_{2}$, and perkaps also to the messenger of stress, absclatc acid; this in turn should help us to understand how plants regulate the gatn of $\mathrm{CO}_{2}$ and the loss of water. This knowiedge may lead to modifications of existing cultivation procedures, directed at the saving of energy and water by crops, to new breeding criterla, and thus to an optimization of enargy conversion by plants for the benefit of man.

III

While plante convert solar into chemical energy, the cultivation of plants requires an investment of additional energy to manufacture the implements of plant culture, to tfll the sol1, to transport, store and process the produce. Crops require energy oubsidies. A large portion of the energy which has thus to be invested goes into the production of fertilizers, with nitrogenous fertilizers accounting for the bulk of thie energy subaldy. For instance, at least one third of the energy Invested in a maize crop is wade through the application of nitrogenous fertilizers; of the natural gas present3y consumed tn-the U.S., 2 percent are used for the reduction of atmospherle nitrogen gas to ammonia for use as fertillzer. A side effect of the high use of fert1lizers in current production practices for most crops is run-off wh1ch results in poilution problems (eutrophication of bodfes of water). There are, however, plante, malnly the legumes which include some Important crops, that are capable of agoinilating nitrogen directly fron the afr. If other crops, particularly the cerealy, could be made to do the same, the expenditure of enargy for production of nitrogenous fertilizere coutd be greatiy reduced, and so could the pollution crused by such fertllizerg.

The enzyne, nitrogenase, responsible for bfological nitrogen flxation, is oxygen-labile. The only organisms known to be capable of flxiug nitrogen $\left(\mathrm{N}_{2}\right)$ at normal amblent levels $(0.2 \mathrm{~atm})$ of oxygen are blue-green algae and Azgtobacter. Fixation by Azotobacter 18 depenaent upon very high rates of resplration of carbohydrate supplied to then. Blue-green algae fix $\mathrm{N}_{2}$ while produc1ng $\mathrm{O}_{2}$ by photosyntheris, and requite only light as energy source. 
These algae have three kinds of celle-vegetative cells, heteracysts, and spores--which differ worphologtcally, blochemically, and functionally. Nitrogen fixation is primexily localized in the heterocysts, but involves a cooperation between these and the vegetative cells. The latter supply the heterocyets with products of photoaynthesis and receive, 1n return, products of $\mathrm{N}_{2}$ fixation.

If--as we are attempting in PEL Task 409 , headed by C. P. Wolk-we can Identify the interactions between vegetative cells and heterocysts, we ahould ackieve a much better underatanding of how $\mathrm{v}_{2}$ fixation might proceed in assoclation with the photosynthetlc tissue of a crop plant. Oux experiments with ${ }^{13} \mathrm{~N}$-labeled nttrogen gag have shown unequivocally that the atmospheric nitrogen flxed by the blue-green alga, Anabaena cylindrics, Is metabolized by the glutenfae synthetase-glutamate eynthase pathway. Suspenstons of heterocysts from this alga couple fixation of nitrogen to uptake of exagenous glutamate, to form glutamine. Wolk and his co-workers are seeking to determine whether it 1n principally glutamine which woves out of heterocysts as a vehicle for net transfer of fixed nitrogen into vegatative cells.

One of the ways that have been proposed to transfer $\mathrm{N}_{2}$-fixing capability to non-legunfnoug crop piants would einultaneously rendex the nitrogenase Imume to amblent $O_{2}$. That way would be to establish a blue-graen alga or an Azotobacter as an endosymbiont within the cello of the plant. The algae have the advantage that thefr nitrogenase activity could be powered by sunlight, rather than by using up carbohydrates which are gynthesized by the host and which might atherwise be transferred as nutrient to the seeds or other storage organg. A necessary condition for stability of such a symbiosis would be, however, that the alga would have to be in some way dependent upon the host. The attempt is therefore being made to isolate auxotrophic mutants of the $\mathrm{N}_{2}-\mathrm{flx}$ ing blue-green alga, Anabaena vartabtlig, 1.e. mutanta which are unable to produce some compound egsential for their growth (e.g. an anino actd) and would therefore depend on the hogt for supply of this "factor". If such mutants can be igolated, we shall try to determine whether they can reproduce stably within plant cells, supplying the host cella with fixed nitrogen. 
IV

While the activities of Tasks 409 and 111 have been expanded, they are "old" takks that have been actlve for several yesrs, productng nany exciting results. Two other Taks are new. One, Tagk\$14, haaded by A. D. Hanson, 18 investigating problens of plant responses to environmental atress. The importance of strees research derives from two considerations, one short-term and the other longer-term. Increases in energy production and the use of new technologieg, or the Increased use of oId ones Itice the predicted Increaged use of conl of which we have spoken, will result in additional environmental stregses, The effects of these stresses on plants needs to be studied and, as far as possible, anticlpated. But no less importantiy, efforts at reducing the energy aubsidies to crops, of which we have also spoken, and efforts at expanding crop production to new areas, mean that crops will have to perforw In higher-gtress enviromments.

Stress research is not anong the most active areas of current plant research. Exlsting methods for identyfying the capacteles of plants to tolerate environmental stresses are nostly tino-copountig and not very reliable (unlike, e.g., methods for measuring responses to nitrogenous fertilizers, or protein quelity). We know little about those tratts that endow a plant with tolerance to stress, and about their Inheritance; the metabolic responges of higher plents to varfous environmental gtresses are also poorly undergtood. The firat objective of Task 014 was therefore the identification and delineation of meaningful reaearch areas. A literature ourvey was undertaken during 1975 and 1976 (in consultation with agxonomists, plant breeders and environmental scientists) to identify problems which Increased energy costs and Increased energy production may ralse in relation to plants, especially crops. The essential parte of this survey have been summarized In a formal report, soon to be avallable. Regearch on the metabolism of plants subjected to water stress appears to have the gxeatest theoreticsl and practical value, for two reasons: first, because water stress (drought) is a najot determinant of vegetation patterns and crop ylelds; and second, because water stress 1 intinataly Interwoven with several other Important environinental stresaes, including 
Btresaes cauged by gallnity, ton toxictty, and treezing.

Experfmental work (started in 1976) has centexed on the accumulation of free proline in the leaves of drought-stressed cereals and rangegrasaes. Theae experimenta were carrted out in collaboration with the Wheat Breeding Program at SSW, because proline sccumulation In cereal seadlings has been proposed ag a blochentcal selection test with a positive correlation to drought resistance in the fiald. Reevaluation of this claim, using one "drought-resistant" and one "drought-susceptible" barley cultivar, showed that the two cultivars did differ markediy in their rates of proline accumulation when under drought-gtre日s. However, this difference could be fully explained by their relative rates of decline in water atatus: The more drought-reslotant cultivar showed a slower decline in water gtatus and acctmulated prolfne at a lower rate than the less restatant one. In general, proline accumulation was found to occur in barley leaveg and leaf zones as a symtom of moderate to severe water stress; the lower the water status, the higher the proline accumilation rate, regardless of cultivar. Wtthin single leaves of moderately drought-stresaed barley there were gradlents both of water status and of proline accumulation rate, with the lowest water gtatus and highest proline accimulation rate at the leaf tx. In leaf zones whlch had accumulated proline during severe water stresa, and then died and became totally dealccated, the proline was retained in the dead leaf zones and was thus logt totally to the living parts of the plent. About $30 \%$ of the original soluble protefn $N$ may be converted to proline and walled off in barley leaveg which die durfing severe water strees. The finding that the highest levels of proline are in dead or dying tlosue casts considerable doubt on the proposed use of proline accumilation as a sinple test showing positive correlation with drought resistance In cereala.

Prelimflary work on the Incorporation of ${ }^{14} \mathrm{C}$ from ${ }^{14} \mathrm{C}$-formate into glycine betalne in barley leaves showed that this 1ncorporation was Increased ten-fold in moderately drought-atressed tiague. The tncreased rate of ${ }^{14} \mathrm{C}$-formate incorporation was accompanied by a two- or three-fold increase in the total amount of betaine in the stressed leaves. 
The second new PRL Task, f015, was Initiated In direct reaponse to $E R D A^{\dagger} s$ need for Information on the impact on plante of expected Increaseg in atmospheric sulfur dioxide $\left(\mathrm{SO}_{2}\right)$ pollution as a byproduct of the expected Increases in burning of coal for energy. P. Filner and L, G. Wilson formed a team to study how $\mathrm{SO}_{2}$ Injures plants, and the mechanisms avajlable in plants for resiating $\mathrm{SO}_{2}$ injury. Filner had worked prevtously on regulation of sulfate assimilation, and Wikson on enzymatic mechantems of sulfate reduction; they thus bring a great deal of potentially applicable knowledge to the project. The real backbone of the project, however, Is a Research Assoclate, Ray Bressan, who vas recruited spectally for 1t. The first goal of the project was to find a plant specter in whtch two cultivarg, organg, or cell types differed in sensitivity to $\mathrm{SO}_{2}$. By couparing the phyoiological and biochemical propertied of such palred blologicel material, it should be pogetble to discern factors responsible for the difference in $\mathrm{SO}_{2}$ sensitivity. Cucurbtt species vere chosen for ocreening becalise of indlcations in gurveyg made 40 years ago that cucurbitg exhibited wide varlations in $\mathrm{SO}_{2}$ sensitivity. An apparatus was degigned and congtructed to permit exposurs of whole plants or plant parts to $\mathrm{SO}_{2}$ at specified concentrations, with continuous monttoring of the amount of $\mathrm{SO}_{2}$ abgorbed by the plante. With thls apparatus, which has been In operation virtually 7 days a week, 24 hours a day, differences in $\mathrm{SO}_{2}$ sensitivity were found among cucurbit spectes (pumpkin being particularly resistant) and also among cultivars of cucumber. The differences in sensitivity between cucumber cultivars has been shown to be based on differences in rate of $\mathrm{SO}_{2}$ absorption, In accord with an oid and previously untested speculation as to why oome specles are more resistant than others. On the other hand, a marked Increage in $\mathrm{SO}_{2}$ sensitivity with leaf age was observed wh1ch cannat be accounted for by differences in $\mathrm{SO}_{2}$ absorption, either per unt leaf area or per leaf ce11. Thus there 1e now reason to belleve for the firat time that there 18 a form of $\mathrm{so}_{2}$ resistance which functiona after $\mathrm{SO}_{2}$ enters the plant, i.e. which has a blochemical bagls, and which 18 under developmental control.

One quite unanticipated finding of the $\mathrm{so}_{2}$ project was that plantg which are fed sulfate through slightly dapaged roote while under high 1ight Intensities (a condition comparable to that in a cultivated fleld) enft hydrogen sulfide $\left(\mathrm{g}_{2} \mathrm{~s}\right)$ for geveral hours. In addition to 
the question of function--does the plant do it for a reasoni-mthis finding has ratsed the Intriguing posibility that cormal plants may under some circumstances be a bignificant wouxce of atmospheris sulfur pollution! Thts discovery was posstble only because of the avaliablitity of the extremely sensitive monitor of volatile sulfur, obtained for the $\mathrm{SO}_{2}$ project. Comparable results are quite difficutt to obtafn by wet chentcal methode because the low rate of $\mathrm{H}_{2} \mathrm{~s}$ emission by planta requires long trapping perlods, whls the trapped $\mathrm{H}_{2} \mathrm{~s}$ oxidizes fairly rapldly.

IV

The changes wich have been made tn the PRI, 's regearch program In 1974-75 are the most congplcuous anes to date but they are not without precedent. Several faculty posittong have changed hands, reoulting in entirely new tasks; reevaluation and modification of the entire program have been going on continuously, alded by loternal reviews of the faculty and input frou an external advisory comblttee, and reflecting the advances in our own work as well as developmenta made in other ingtitutions, And this process of self-regulation w11 and should continue, as there will be other personnel changes, wore new developments will have to be Integrated fnto. the program, and the needs of the supporting agency, ERDA, will undoubtedly change, too, At the same tine, the contenulty of the Laboratory's research program should not be jeopardized; additlong and other changes ghould on the one hand be grounded in existing strengths, and on the other ahould fead back Into these otrengths. The changes wh1ch were planned in 1974-75 and inplemented in 1975-76 have, we feel, struck such a balance, For exanple, the expanded work on nitrogen fixation in blue-green algae, apart fron ito Intrinsic algnificance, has provided valuable leads to the understanding of the chemical interdependence of the dtfferent cell types of these organisms and has thus atrengthened this oldar and previously predontnant project of Task 09. Stmillarly, the work on $\mathrm{SO}_{2}$ effects, in addition to providing sone information about the sites of $\mathrm{sO}_{2}$ resistance in plants--Informstion of potential significance for Identifying and perhaps allevtating $\mathrm{SO}_{2}$ demage-has led to the realization of metabolic activities of plants $\left(\mathrm{H}_{2} \mathrm{~S}\right.$ release) the exiatence of which had not been realized before. Thus, those changes in the regearch program of the PRL can serve as models or guides in further modifications within, and additions to, this program. 


\section{Teaching}

The following faculty wenbers particlpated on a regular basis in snstruction (schaduled caurseg, excluding research):

Deborah Detmer

Blochemistry 200. Introduction of Blochemlatry (5 credits)* Blochemsatry 855. Plant Btocheniatry (3 cred1ts)

Fhilip Pitner

B1ochentstry 452. Blochenistry (4 credits)*

Alfrod Bang

Blophysics 402. Introductory Blophyalca (3 credits) ${ }^{* k *}$

Blophyaice 890. Reedinga In Blophyaica (3 credits; taught 2 terms)

Hans Kende and Jan Zeevanpt

Botany 415. Plant Physlology: Growth and Development (5 credtts)

Kemeth Poff

MLcroblology 900, Topicg In Microbiology (3 credits)*

Klows Rasohke

Botany 954. Advanced Plant Phyglology IV (3 credite)

Jan Zeevant

Botany 953. Advanced Plart Phyolology III (3 credits)

* Jointly with another instructor

** Jofntly with two other Instructors

*** Jointly with several other instructors 


\section{Trating}

The following graduate students (graduate assistants) workting in the Laboratory obtained their degrees:

Ngme

Pregent location and position

(In parentheses, thesis supervi,or and KSU Department conferring degree)

Liliana Cardemi1, Ph.D.

(C.P. Wolk; Botany \& PIant

Pathology)

David T. E. Bo, Ph.D.

(J.E. Varner; Biochemistry)

Maureen MeInert, M.S.

(D.P. Delmer; Blochemistry)

Z1va Reuveny, Ph.D.

(P. Filner; Blochemistry)
Pacultad de cienctas, tontverstead de Chile, Santlago, Profeggor

Department of Blology, Waghington Jufversity, St. Louls, Misgourt,

Regearch Agsoctate

Department of Blochemistry, Michigan

State Unfversity, Eagt Lansing,

Mtchigan, Specialist

Biology Division, Oak Riđge National

Laboratory, Oak RIdge, Tennesgee,

Research Associate

The following reaearch agsoctateg completed their periods of work and training In the Laboratory; * indicates an investigator who was on leave from and has returned to his hone institution, and who had his personal support:

Name Present location and posttion

(in parentheses, supervising faculty member)

Robert F1sher

(C.P. Wolk)

Ursula Helniger

(D.P. Delmer)

Phelip Nordin

(D. T. A. Lemport)
Department of Biology, Virginia

Cominonwealth University, Rfchmond, Assiatant Professor

Institut de Physiologle végetale et de Phytochtmie, Université de Fribourg,

Swltzerland, Research Blologist

Department of Btochemistry, Kangas

State University, Manhattan,

Professor 
Faculty activitles, functions, honore, etc.

H. Kende became a member of the Advisory Padel for Developmental Btology, National Sclence Foundation. A, Lang was elected an Honorary Vice Prealdent of the XII International Botanical Congress, Lenlngrad, USSR, July 1975. He started a sabbatical leave at the $\mathrm{K}$. A. TImiryazev Ingtitute of PIant Physiology of the Academy of Sciences of USSR, Hoscow, under the Sctentific Exchange Program between the National'Academy of Scfenceg and the Acadeny of Sclences of USSR (Augtust 11, 1975). $X$. Rasahke returned from a sabbatical Leave, spent at the Botanical Institute, Technical Untversity, Hunich, Germany with support from the John Simon Guggenheln Foundation (August 31, 1975). 
PERSONAEL,

Faculty, Including Joint Appointments

Deborah P. Delmer, Asalstant Professor of Blochemistry

Philip Filner, Professor of Biochentstry

Alfred Haug, Profeseor of Blophystes

Michael Jost, Associate Professor of Botany and Plant Pathology

Hans J. Kende, Professor of Botany and Plant Pathology

Derek T. A. Lamport, Professor (Research)

Anton Lang ${ }^{1}$, Director and Professor of Botany and Plant Pathology

Kenneth L. Poff, Assistant Frofeseor of Botany and Plant Pathology

KIaus Raschke, Professor of Botany and Plant Pathology

Lloyd G. Wtlson, Associate Professor of Botany and Plant Fathology (Research)

C. Peter Wolk, Profeasor of Botany and Plant Pathology

Jan A. D. Zeevaart, Professor of Botany and Plant Pathology

Research Speciatists (Including supervising faculty member)

Graham Farquhar (K. Raschke) From July 1, 1975

Andrew Hangon (A. Lang) From July 1, 1975

Regeaxch Associates (1ncluding supervising faculty member)

Peter Beutelmann ${ }^{2}$ (H. Kence) From September 1, 1975

Kary Exicson (D. DeImer)

Grahaw Farçuhar (K. Raschke) Until June 30, 1975

Stuart Flashman (P. Filnex) From November 1, 1975

Robert Fisber (P. Wolk) Unt11 August 31, 1975

Gary Gardner ${ }^{3}$ ( $H$. Kende)

Andrew Hangon (E. Kende) Unt1 June 30, 1975

IOn sabbatical leave from August 11, 1975

2 Supported by Hax Kade Foundetion

${ }^{3}$ Partlally supported by a grant from the National Sclence Foundation to $\mathrm{H}$. Rends 
Ursula Heiniger (D. Delmer) Until Decenber 31, 1975

Katsushi Manabe (K. Poff) From February 16, 1975

John Meeks (P. Wolk) From August 16, 1975

Harry Philifps (H. Kende) From Septenber 16, 1975

Hartmut Quader ${ }^{1}$ (P. Filner) From October 1, 1975

Robert Saftner (K. Raschke) Fron October 1, 1975

Werner Schmidt ${ }^{1}$ (K. Poff) From October 1, 1975

Joseph Thomas ${ }^{2}$ (P. Wolk)

Ludo Van Rompuy (J. A. D. Zeevaart) Frow January 1, 1975

Graduace Assistants (Including departmental affiliation and superviging faculty member)

Kent Bradford (Horticulture) - H. Kende and D, R. DIlley

(Department of Hort1culture)

*Charles Celduell (Boteny and Plant Pathology)

Lillans Cardemtl de Balboa (Botany and Plant Pathology) - P. Wolk

Jntil October 15, 1975

Judith Cherntack (Blochemistry) - P. Filner

Dean Dubbe (Botany and Plant Pathology) - K, Raschke

Taksyasu Hitrosana (Botany and Plant Pathology) - P. Wolk

David Tuan-Hua Ho (Blochemistry) - J. E. Varner

Unt11 0ctober 15, 1975

Jean-Cheud Hsung (Blophysics) - A, Haus

*David Kavor (Botany and P1ant Pathology)

*Cynthla Kennedy (Botany and Plant Pathology)

*Anlta Klein (Biochemistry)

Kenneth Leonarde (Botany and Plant Pathology) - A, Haug and

B. Cantino (Department of Botany and Plant Pathology)

*David Maltby ${ }^{3}$ (Btocheatstry)

Maureen Melnert (Blochemtstry) - D. De1mer, Until September 15, 1975

James Metzger (Botany and Plant Pathology) - J. A. D. Zeevaart

$1_{\text {Supported by Deutache Forachungsgemelnschaft (DFG) }}$

2 Partlally supported by a grant from National Science Foundation to C. P. Wolk

${ }^{3}$ Supported by a tratning grant fxom the National Institutea of Eealth to

the Department of Blochemistry

*Has not yet chosen a major advisor 
Andrew Kort (Botany and Plent Pathology) - D. T. A. Lamport Margaret Pierce (Botany and Plant Pathology) - K, Maschke

*Louls Ptak (Botany and Plant Pathology)

Ziva Reuveny (BIochemistry) - P. Filner, Until August 1, 1975

Shirley Rodaway (Botany and Plant Pathology) - H. Kende

Tom Skokut (Botany and Plant Pathology) - P. F1lner, P. Wolk

Michael Subsman ${ }^{1}$ (Botany and Plant Pathology) - H. Kende

Jeffrey Suttle (Botany and Plant Pathology) - H. Kende

Carol Van K1rk (Botany and Plant Pathology) - K, Raschke

Herwan Weller ${ }^{2}$ (B1ophysics) - A. Haug

Bruce Whitaker (Botany and Plant Pathology) - K. Poff

Narendra Slngh Yadav (Botany and Plant Pathology) - P. Filner, H. Kende LI L.tllian Yang (Biophysics) - A. Haug

Technical Personnel (Including supervising faculty merber; if none listed -general service)

Susan Atkins, Senfor Techaician (P. Filner)

James Brede, Sentor Techntclan (J. A. D. Zeevaart) Unt1l January 9, 1975

Hichael Caughey, Senior Techntcian (D. T. A. Lamport)

Charles Cetas, Seafor Technician (J. A. D. Zeevaart)

Alma Clark, Senior Laboratory Aselutant.

Renate de Zacks, Principal Technlcien (H, Kende)

Robert Geyer, Ingtrument Maker and Shop Supervieor

Alicta Green, Itbrarjan, Unt1l Septerber 30, 1975

Marina Kao, Sentor Techoician (K, Raschke)

Robert Kever, Equipment Technician

Carl Kulow, Sentor Techniclan (D. De1mer)

E1liot Light, Superviaor Research

Anna Owens, Sentor Laboratory Assistant

Raymond Sculley, Prfnctpal Technician (K. Jost) Until August 1, 1975

1 Partialiy supported by a predoctoral fellowshlp frow the National

Science Foundation

${ }^{2}$ Supported by a training grant from the National Ingtitutes of Health

to the Department of Biophysics

*Has not yet chosen a major advisor 
Faul Shaffer, Senior Techntcien (P. Wolk)

Thonas Sharkey, Sentor Technician (X. Raschke)

Kichiyo Skokut, Sentor Tachnician (K. Poff)

Gary Smtth, Sentor Techntcian (A. Haug)

Henry Wiefer1ch, Mechanteal Technic1an

Elizabeth Wojcluch, Sentor Technlclan, Unt1l February 7, 1975

\section{Adminfatxative and Clerical Personnel}

Karen cline, Sentor Departmental Secretary

Homer K. Curtis, Aduintstrative Assistant

Kathryn Harmon, Princlpal Clerk

Tawn Jarvis, Sentor Clerk Stenographer 


\section{PUBLICATIONS}

* 1) Austin, S., A. Galonsky, J. Bortins and C. P. Wolk: A batck process for the production of $13 \mathrm{~N}-1$ abeled nitrogen gas. Nuclear Inst. Meth. 126:373-379 (1975).

2) Baungartner, B,, H. Kende and P. Matlle: Ribonuclease in senescing morning glory: purtification and demonstration of de novo synthesis. Plant Phygio1. 55:734-737 (1975).

3) Chapran, K. S. R., A. Trewavas and I. C. van Loon: Regulation of the phosphorylation of chromatin-associated protelns In Lema and Hordetm. Plant Physto1. 55:293-296 (1975).

4) Durley, R. C., R. P. Pharis and J. A. D. Zeevaart: Metabolism of [3H]-Gibberellin A20 by plants of Bryophy IIum daigremontianum under long- and short-day condttiong. Planta (Berl.) 126:139-149 (1975).

5) Firn, R. D.: On the red light inhibition of pea internode elongation, with an emphasis on the role of xanthoxin. In: Plant Growth Substences 1973 (8th Internat. Conf. on Plant Growth Substances., Tokyo), Hirokawa Publ. Co., Inc. 1974, pp. 1225-1230.

6) Flint, D., G. S. Ayers and S. K. Rieg: Synthesis of endosperm protelns in wheat seed during waturation. Plant Physiol. $56: 381-384$ (1975).

7) Hanson, A. D. and H. Kende: Ethylene-enhanced ion and sucrose efflux in morning glory flower tissue. Plant Phys1ol. 55:663-669 (1975).

8) Holzapfel, C. and A. Haug: Tye course of microsecond delayed light entsaton from Scenedeamus obliquks at intermittent illumination. Photochem. Phatobiol. 21:209-211 (1975).

9) Ho, D. T.-H. and J. G. ScandalLos: Regulation of alcohol dehydrogenases tn malze scutelium during gexmination. Plant physiol. $56: 56-59$ (1975).

10) Faung, J. C. and A. Haug: Intracellular pH of Thermoplasma acidophita. Blochtin. B1ophys. Acte $389: 477-482$ (1975).

11) Kende, H., M. Fulcuyama-Dilworth and R. dezacks: On the control of ritrate reductase by nitrate and benzyladesine in Agrostemina git thago embryos. In: Flant Growth Substances 1973 (8th Internat. Conf. on Plant Growth Subetances, Tokyo), Hirokawa Publ, Co., Inc. 1974, Pp. 675-682.

12) Raschie, K.: Abscisic actd sensitizes stomata to $\mathrm{CO}_{2}$ in leaves of Xanthium atmamamion L. In: Flant Growth Substances 1973 (8th Internst. Conf. on Plant Growth Stbstances, Tokyo), Hirokawe Pub1. Co., Inc. 1974, PP. 1151-1158. 
*13) Raschke, $K_{n}$ : Simultaneous requirement of carbon dioxide and abscisjc acid for stamatal closing in Xanthium stmonamium L. PIanta (Ber1.) 125:243-259 (1975).

14) Raschke, X: Stomatal action. Ann. Rev. Plant Phys fol. 26:309-340 (1975).

15) Raschke, K., R. D. Firn and $M$. Plerce: Stomatal closure in response to xanthoxin and abscisic acid. Planta (Ber1.) 125:149-I60 (1975).

*16) Ruwart, M. J. and A. Haug: Menbrane properties of Thermopiasma aciaophita. Biochenistry 14:860-866 (1975).

17) Ruwart, M. J., J. F. Holland and A. Haug: Fluorimetric evidence of Interactions involving cryoprotectants and biomolecules. Cryobiology 12:26-33 (1975).

18) Thomas, J., C. P. Wolk, and P. W. Shaffer, S. M. Austin and A. Galonsky: The inftial organic products of fixation of $13 \mathrm{~N}$-labeled nitzogen gas by the blue-green alga Anabaena cylindrica. Btochen. Biophys. Res. Colmun. $67,501-507$ (1975).

*19) van Loon, I, C., A. Trewavas and K. S. R. Chapman: Phosphorylation of chromatin-assoctated proteins in Lemnd and Hordewn. Plant Physiol. 55:288-292 (1975).

20) Wolk, C. P.: Dffferentiation and pattern formation in filanentous blue-green algae. In: Am. Soc. Microbiol., Spores VI

(P. Gerhardt et al., eds.), Washington, D.C.: 1975, pp. 85-96.

21) Wolk, C. P. and M. P. Quine: Forwation of one-dimensional patteras by stochastic processes and by filamentous blue-green algae. Dev. B1o1. 46:370-382 (1975).

22) Yang, N.-S., and J. G. Scandalios: Cytoplasintc systhesis of soluble and mitochondrial malate dehydrogenase isozymes in maize. Arch. Btochem. B10phys. 171:575-585 (I975).

23) Yang, N.-S, and J. G. Scandalios: De novo synthesis and developmental contro1 of the muttiple gene-controlled nalate dehydrogenase isozymes in maize scutella. Bfochim. Biaphys. Acta 384:293-306 (1975).

24) Zeevaart, J. A. D.: Endogenous gibbereliins and growth responses in gpinach under different photoperlods. Flant Growth Substances 1973 (8th Internat. Conf, on Plant Growth Substances, , Tokyo), Hicokawa Pub1. Co., Inc. 1974, pp. 1175-1181.

Reprints of the publications listed above, except those narked *, are available for distribution to interested investigators, as long as the supplies last. If interested, mark desired reprints on form below and wail to: 
MSU/ERDA Plant Research Laboratory

Mehigen State University

East Lans1ng, M1ch1gan 48824

Please send one copy each of publications marked below:

$1,2,3,4,5,6,7,8,9,10,11,12,13,14,15,16,17,18,19,20$, $21,22,23,24$

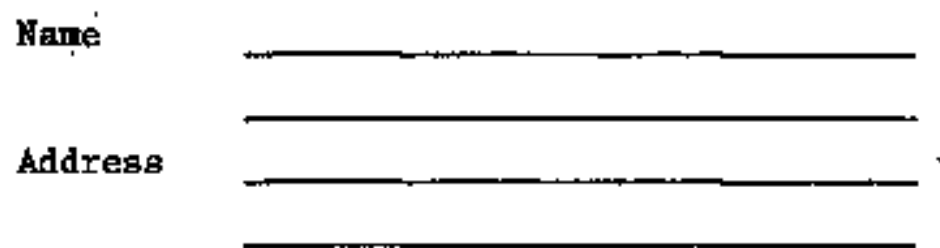


MEETLNGS, SEMINARS, LECTURES

Anmal Meeting of the Anemion Socisty of Plant Phyaiologists, Corvallis, Oregon (August 1975): Papers were glven by D. P. Delmer on "UtIIization of UDP $\leadsto$ gticose by detached cotton fubers" (co-authored with $\mathrm{C}$. Kulow); U. HeIniger on "Utilization of UDP-glucose by a particulate fraction of cotton fibers" (co-authored with D. Delmer); P. Filner on "Apparent derepression of ATP sulfurylase in response to restriction of sulfur supply in cultured tobacco cells" (co-authored with 2 . Reuveny); G. Farquhar on "Dynamic stomatal behavior"; M. Pierse on "Stomatal closure in response to xanthoxin and abscisic actd" (co-authored with R. D. Firn and $K$. Raschke); A. Mort on "Evidence for polyaaccharide attachment to extensin in cell walls obtained fron tomato ce11 suspension cultures" (with D. T. A. Lamport); G. Gardnex on "Cytokinin binding to particulate fractions from moss protonenata" (co-authored with H. Kende and M. Sussman); A. D. Hanson on "The blosynthetlc pathway of ethylene in excised flower tissue of Ipomoed toitootor" (co-authored with H. Kende); $H$. Kende on "The regulation of aging in excised flower tissue of Ipomosa tricolorit (co-authored with A. D. Hanson); M. Sussman on "Gytokinin binding to particulate fractions from tobacco callus" (coeuthored with $\mathrm{H}$. Kende); R. W. Fisher on "A substance stimulating sporulation of a blue-green aIga" (co-authored wtth C. P. Wolk); K. Pofe on "Thermotaxis by pseudoplasmodia of Diotyoste livm discoidew";

J. A. D. Zeevaart on "Comparative studies on phloem exudaction from Induced .. and _non-jinduced_Peritia leaves."

Anrual Neeting of the Miduest Section of the Amerian Society of Plant Physiologists, Bradley Univeraity, Peoria, Illinois (Jione 1975): Papers were given by $M$. R. Sussman on "Synthesis of high specific activity benzyladenine-benzyI- $\mathrm{p}^{3} \mathrm{H}^{* 1}$ (co-suthored with $\mathrm{R}$. Firn and $\mathrm{H}$. Kende); A. Hanson on "Ethylene production and aglng in excised flower tissue of Ipomoed thicolop" (co-authored with H. Kende); S. Rodaway on "Effect of 5-fluorouractl on the thermolability of a-amylase from barley half-seeds" (co-authored with H. Kende); M. Ericson on "Lipid Intermediates involved in the synthesis of a plant glycoprotein" (co-authored with D. Delmer); U. Helniger on "UDP-glucose utilization in cotton fibers"; $M$. Meinert on "The primary cell wall of the cotton fiber" (co-authored with D. Delmer); M. Pierce on "Stomatal closure in response to xanthoxin and abscisic acld" (co-authored with $\mathrm{K}$. Raschke and $R$. Fim); L. Wilson on "Enzymatic sulfate reduction in yeast"; A. Mort on "Evidence for the attachment of a polysaccharide including a polyrhamnogalacturonan to 'extensin', the hydroxyproline-rich cell wall protein"; L. Cardentl on "Structuzal analysis of the polysaccharides from spore and heterocyst envelopes of a blue-green alga" (co-authored with C. P. Wolk); G. Fatquhar on "Resistance to evaporation of the mesophy11 cell wall"; R. Fisher on "A substance stimulating sporulation of a blue-green alga" (co-authored with C. P. Wolk); K. Manabe on "Absorbance changes induced by light In corn coleoptiles" (co-authored with K. POfE). 
XII Intermational Botaniad Congress, Leningrad, uSSR (July 1975):

A. Lang chaired the symposium "The role of the USSR Acadeny of Sclences in the development of botany". Papers were presented by D. Delmer on "The posstble role of lipid intermediates in glycoprotein synthesis in higher plants" (co-authored with M. Ericson); D. Delmer on "The utflization of UDP-glucose by developing cotton ffbers" (co-authored with U. Heiniger); A. Hatg on "Membrane atructure of Themoptasma acidophita (co-authored with J. C. Hsung); A. Lang on "Environment and internal mechanisms of autogenesis regulation" (Symposium "General aspects of plant ontogenesis"); D. T. A. lamport on "Evidence for galactosy1 aerine as a major site of polysaccharide attachment in extensin"; K. Raschke on "The stonatal feedbsck system responses to carbon dioxide and abscistc acid" (Sympostum "The mechanism of stomatal movements").

L. Cardemit presented a paper on "Structural analysis of the backbones of the polysaccharides from spore and heterocyst envelopes of a bluegreen alga" (co-authored with C. P. Wolk) st the Annual Meeting of the American Soclety for Microbiology, Nev York City, N.Y. (May 1975).

$P$. Fitner gave seminars on "Regulation of two functionally convergent pathways in higher plants: nitrate and sulfate assimilation" and "Taking apart and puttlng cogether microtubules in vitro" at Washington State University, Genetics Progran, Puliman (Apri1 14, I5 1975) and on "Interactions of colchictne and nicrotubules" at the Untversity of Washington, Department of Botany, Seattle (AprtI 16, 1975).

G. Gardner gave seminars on "Molecular characteristies of phytochrome" at the University of Massachusetts, Department of Botany, Amherst (January 16, 1975); "Propextles of phytochrome" at Arlzona State Untversity, Department of Botany, Tenpe (February 19, 1975) and at Rutgers Univers 1 ty, Departnent of Biochemistry and Pficrobiology, New Bxunswick, New Jersey (May B, 1975); "Hotmane receptors in higher plants" and "Proteolysia of phytochrone" at Kansas Stace University, Division of Blology, Manhattan (May 19 and 20, 1975); "Cytokinin binding in a particulate fraction from moss extracts" at Pilnceton University, Department of Btology, Princeton, New Jersey (Decerber 2, 1975) and at Smithsonian Institution, Radiation Biology Laboratory, Rockville, Maryland (December 5, 1975); "Cytokinin binding in moss extracts" at the University of North Carolina, Department of Botany, Chapel H111 (December 8, I975).

A. Hanson gave a seminar on "Ethylene and senescence in morning glory flowers," at Monsanto Agrlcultural Division, St. Louis, M1ssour1 (February 24, 1975).

A. Houg gave a seminar on "Regulation on membrane lipld fluidity In Mycoplasma," at the V. L. Komarov BotanicaI Institute, Myxomycetes Group, USSR Academy of Sciences, Leningrad, USSR (July 10, 1975). 
H. Kende presented a paper at the Gordon Research Conference on Postharvest Physlology, Santa Barbara, Calffornia on "The effect of ethylene on compartmentation during senescence" (June 23-27, 1975); and gave seminers on "On the regulation of plant senescence by ethylene" at Harvard University, Btological Laboratories, Cambridge, Massachusetts (Hay 29, 1975); and "On the role of ethylene in the senescence of morning glory flowers", at the U.S. Department of Agriculture, Beltsville, Maryland (October 15, 1975).

A. Lang during a sabbatical leave in the USSR, gave seminars on "Plant hormones--advances and open questions" at the Institute of Plant Physiology and Blochemistry, Siberian Division, Acadeny of Sclences of USSR, Irkutsk (August 26, 1975); the Institute of Agrochentcal Problems and Hydroponics and the Botanical Institute of the Academy of Sciences of the Atmentian SSR, Erevan (September 11 and 12, respectively), the Botanical Institute, Academy of Sclences of the Ukrainian SSR, Ktev (September 23, 1975) and the K. A. Timiryezev Institute of Plant Physlology, Acadeny of Sciences of USSR, Moscow (November 19, 1975); taiks on the organization and research program of PRL at the Nikita State Botanical Garden, Yalta, Crimea (September 17, 1975) and the K. A. Timiryazev Institute, Moscow (December 16, 1975); and a lecture on "Early stages in plant development" also at the latter institute (November 21,1975 ).

D. T. A. Lomport gave seminars on "Extensin ellminated: new evidence for the role of a hydtoxyproline-rich macronolecule in plant cell wa11s" at Kansas State Inlversity, Department of Blochemistry, Wanhattan, (Apr11 27, 1975); and "Do the hydroxyprollne-rlch glycoprotetns of plant cell walls throw any light on the origin of multicellular eukaryotes?" at Iowa State UnIversity, Department of Botany and Plant Pathology, Ames (Novembér 9, 1975).

K. Poff presented papers "Effects of 11ght on Bictyosteliwn discoidew" at the Slime Mould Workshop, University of Essex, Colchester, England (Aprf1 1975); "Thermotaxis in Dictyostetitun" and "The photoreceptor. p1gment for phototrop1sm" at the Gordon Conference on Sensory Transduction in Mtcroorganisns, Santa Barbatáa, California (December 1975); "Absorbance changes associated with the blue 1ight photoreceptor pigment" (co-authored with $W$. Butler) at the Annual Meeting of the Amertcan Soc1ety of Photobiologists, Louisville, Kentucky (June 1975); and gave sentnars on "Photoreceptors of Diatyostetion discoideum" at the Max-P1anck Institut flir Ernährungsphysiologie, Dortmund, Germany (April 1975); "The photoreceptor pigment associated with phototropism in Phycomyces", at the Max-Planck Institut für Molekulare Genetik, Berlin, Germany (Apr11 1975); "Photoreceptors In Didyosteliwm, Neurospora and corn" at the University of Frefburg, Institut fitr Blologie II, Fretburg, Germany (Apr1l 1975); "The photoreceptor pigment of phototaxis in the cellular slime mold, Dictyostetiun discoideum" at the State University of Antwerp, Department of General Botany, Antwerp, Belgium (April 1975); "Thermosensory physiology" at the Carnegie Institute of Wastington, Plant Blology Department, 'Stanford, California (August 1975). 
K. Raschke presented papers on "How stomata resolve the dilemina of opposing priorlties" at the Meeting for Discussion on Water Relations of Plants, The Royal Society, London (January 1975); and on "Transfer of tons and products of photosynthesis to guard cells" at the U.S.Australia Sclence Agreement Conference on Transport and Transfer Processes in Plants, Canberra, Australia (December 1975). He also gave seminars on "Stomatal regulation of water loss: hydraulzes and hormonics" at the Unfversity of Lancaster, Department of Blological Sctences, Lancaster, England (February 1975); "Die Regelung deg Wasserhaushal tes in der Pflanze" at Ciba-Geigy Ltd., Babe1, Switzerland (March 1975); "Stomata im Dilenma zwlschen Durst und Hunger" at K1einwanzlebener Saatzucht A.G., Einbeck, Germany (Apr11 1975); "Spaltöf fnungsbeweging: Alkali, Apfelsäure, Abszisinşure" at University of Göttingen, Botanische Anstalten, Göttfngen, Germany (Apr11 1975); "Stonabewegung: Mechanik und Metabolik", Ruhr-Universität Bochum, Germany (June 1975); "Zum Mechandsmus der atomätaren Regelung von Transpiration und Photosynthese", Uaiversity of Tibingen, Institut für Biologie, Germany (Jtune 1975); "Neue Untersuchungen über den Mechanismus der Stomatabewegungen", Colloquium of the Botanteal Institutes of the Uatverstey und the Techntcal Untversity, Munlch, Germany (June 1975); "Ionentransport und Säturestof fwechsel a1s Ursachen der Stomabewegung", Kernforschungsanlage Jülich, Institut fïr phystkalische Chemie, Germany (December 1975); "Stomatal movement: mechanics and metabolics" at Valcani Center, Bet Dagan, Is rael (December 1975); "Stomatal regulation of photosynthesis and transpiration" at the India Meteorological Department, Agricultural Meteorology Division, Poona, India (December 1975).

c. $P$, Wolk gave sejminars on "Differentiation and pattem formation in filamentous blue-green algae" at Ketteting Research Laboratory, Yellow Springs, Ohio (March 12, 1975); and "Developmental biology of the blue-green algae" at the University of Mnnesota, School of Medicine, Department of Mtcroblology, Minneapolis (Novenber 12, 1975).

J. A. D. Zeevaant gave a seminar on "Hocmonal control of flower formation", Washington University, Department of Blology, St. Louls, Missouri (Apri1 21, 1975). 
PRL SEMINAR SERIES

Speaker and

Date

January 8, 1975

January 15, 1975

Januacy 22,1975

January 29, 1975

Februacy 5, 1975

February 11, 1975

February 12, 1975

February 19, 1975

February 26, 1975

March 5, 1975

Warch 20, 1975

\section{Institution}

Dr. R. J. Huskey

Un1verstty of Virginta

Charlottesville, Virginia

Dr. J, A, D. Zeevaart

MSU/ERDA Plant Research Lab

Dr. R. Hertel

University of Freiburg

Freiburg, Germany

Dr. L. Bogorad

Harvard Unfversity

Cambridge, Massachusetts

Dr. M. Zaitinn ${ }^{2}$

Cornel1 Untversity

Ithaca, New York

Dr, R, Lozier ${ }^{3}$

UnIverstty of Califordia

San Diego, Caltfornia

Dr. D.P.S. Verma

McGiIl Univergity

Montreal, Canada

Dr, R. Herte1

University of Freiburg

Fretburg, Germany

Dr. J. A. Bassham ${ }^{4}$

Lawrence Berkeley Laboratory

Untversity of Cal1fornda

Berkeley, Calffornia

Dr, J, E, Varner

Washington University

St. Louts, MissourI

Dr. S. Roseman 5

The Johns Hopkins University

Baltimore, Maryland
Subject

Genetlc control of development in votvox

Metabollsm of abscistc actd in bean seed11ngs

In vitro auxin binding

Complementary chromstic adaptation -- a problem in developmental biology

Replication of tobacco mosaic virus

Light energy transduction by the purple membrane of Hatobasterium hatobitum

The regulation of leghemoglobin gene expression during synbiotic nitrogen fixation

The nature of the bluelight receptor pigatent in plants

Me tabolic regulation of phocosynthetic carbon me tabolism

Control of synthesis and secretion of the yeast glycoprotein enzyues

Studies on a bacterial phosphotransferase and its role In ougar transport 


$\begin{array}{ll}\text { Date } & \text { Speaker and } \\ \text { Mnstitution }\end{array}$

Subject

Possible influence of iontc composition on the structure of

bilayer lipid membranes

The role of tugor pressure in growth and growth storage

Biological effect of membrane 1ipid physical atate in cultured mammalian fibroblasts

Hicrotubules and microfilaments: the1r role in motility and morphogenesis of plant cells

Why is a multienzyme complex?

Can you take the pulse of turnips? (A contractile model of phloem transport)

Genetic engtneering for nutritional quality in food crops

The properties of photosynthesis affecting crop productivity

Assembly and maturation of the aftrate reductase in $E$. coti

Osmotic and turgor regulation in plant ce1ls

Possible role of ethylene in cyanideresistent respiration of plant mitochondria 


\begin{tabular}{|c|c|}
\hline Date & $\begin{array}{l}\text { Speaker and } \\
\text { Institution }\end{array}$ \\
\hline Hay 28, 1975 & $\begin{array}{l}\text { Dr. L. Margulis } \\
\text { Boston University } \\
\text { Boston. Massachusetts }\end{array}$ \\
\hline Nay 29, 1975 & $\begin{array}{l}\text { Dr. C. E. Ballou } \\
\text { UnIverstty of Caltfornta } \\
\text { Berkeley, Califomia }\end{array}$ \\
\hline June 16,1975 & $\begin{array}{l}\text { Dr. J. DeGreef } \\
\text { State UnIversity of Antierp } \\
\text { Antwerp, Belglum }\end{array}$ \\
\hline July 3,1975 & $\begin{array}{l}\text { Dr. U. P, Hansen } \\
\text { Univers1ty of Kiel } \\
\text { Kte1, Geinany }\end{array}$ \\
\hline Augugt 8, 1975 & $\begin{array}{l}\text { Dr. K. Wothes } \\
\text { Institut fur Bjochemie der } \\
\text { Pflanze } \\
\text { Halle, Gectan Democratic } \\
\text { Republic }\end{array}$ \\
\hline September 9, 1975 & $\begin{array}{l}\text { Dr. J. Eber } \\
\text { University of Colorado } \\
\text { Boulder, Colorado }\end{array}$ \\
\hline September 26, 1975 & $\begin{array}{l}\text { Dr. W. W. Schwabe } 10 \\
\text { Wye College } \\
\text { University of London } \\
\text { Kent, England }\end{array}$ \\
\hline October 1,1975 & $\begin{array}{l}\text { Dr. J. Boyer } \\
\text { Universtty of Ill1nofs } \\
\text { Urbana, Illinods }\end{array}$ \\
\hline October $B, 1975$ & $\begin{array}{l}\text { Dr. M. H. Goldsat th } \\
\text { Yale University } \\
\text { New Haven, Connecticut }\end{array}$ \\
\hline October 17,1975 & $\begin{array}{l}\text { Dr. R. C. Valentine } \\
\text { Plant Growth Laboratory } \\
\text { University of California } \\
\text { Davis, California }\end{array}$ \\
\hline Dctober 22, 1975 & $\begin{array}{l}\text { Dr. W. R. Brigge } \\
\text { Carnegie Institution } \\
\text { of Washington } \\
\text { Stanford, California }\end{array}$ \\
\hline
\end{tabular}

Subject

Evolutionary consequences of symbiosis and the orfigin of cells

Recent developments on the strticture and biosynthesia of yeast cell wall mannan

Rapid physiological changes controlled by phytochrame

Time constants in the effect of light on wembrane potential of Witelia

Secondary metabotism In plants
Enzymes of phenylpropanatd
metabolfsm in cell suspen-
sion cultures of plants
Apical gxowth and leaf
positloning in higher plants

Nitrate reduction in plants having low water potentials

Does a pH gradient drive polar auxin transport?

Molecular biology of nitrogen fixation

Iavestigations on the blue light photoreceptor 


\begin{tabular}{|c|c|c|}
\hline ate & $\begin{array}{l}\text { Speaker and } \\
\text { Institution }\end{array}$ & Subject \\
\hline ovember 5, 1975 & $\begin{array}{l}\text { Dr. T. Hodges } \\
\text { Purdue University } \\
\text { West Lafayette, Indiana }\end{array}$ & $\begin{array}{l}\text { Selectivity of fon trans- } \\
\text { port in roots }\end{array}$ \\
\hline November 12,1975 & $\begin{array}{l}\text { Dr. L. Mortenson } \\
\text { Purdue University } \\
\text { West Lafayette, Indiana }\end{array}$ & $\begin{array}{l}\text { Studies on the role of } \\
\text { molybdenum in dinitrogen } \\
\text { fixation }\end{array}$ \\
\hline November 14,1975 & $\begin{array}{l}\text { Dr, 0. Björkman } \\
\text { Carnegle Institution } \\
\text { of Washington } \\
\text { Stanford, Californta }\end{array}$ & $\begin{array}{l}\text { Photosynthetic response } \\
\text { and adaptation to extreme } \\
\text { environients }\end{array}$ \\
\hline November 19, 1975 & $\begin{array}{l}\text { Dr. D. Weeks } \\
\text { Institute for Cancer } \\
\text { Research } \\
\text { Philadelphia, Penneylvanla }\end{array}$ & $\begin{array}{l}\text { Regulation of microtubulin } \\
\text { synthesia in chlamidomonas } \\
\text { peinharait }\end{array}$ \\
\hline December 3, 1975 & $\begin{array}{l}\text { Dr. R. Keates } \\
\text { McMaster University } \\
\text { Hamilton, Ontarto, Canada }\end{array}$ & $\begin{array}{l}\text { The accessory protein of } \\
\text { microtubules }\end{array}$ \\
\hline December 10,1975 & $\begin{array}{l}\text { Dr. J. S. Lovett } \\
\text { Purdue University } \\
\text { West Lafayette, Indiana }\end{array}$ & $\begin{array}{l}\text { Regulation of RHA and pro- } \\
\text { tein synthesis in the } \\
\text { zoospores and during } \\
\text { zaospore germination in } \\
\text { Blastoctadielza }\end{array}$ \\
\hline \multicolumn{3}{|c|}{ 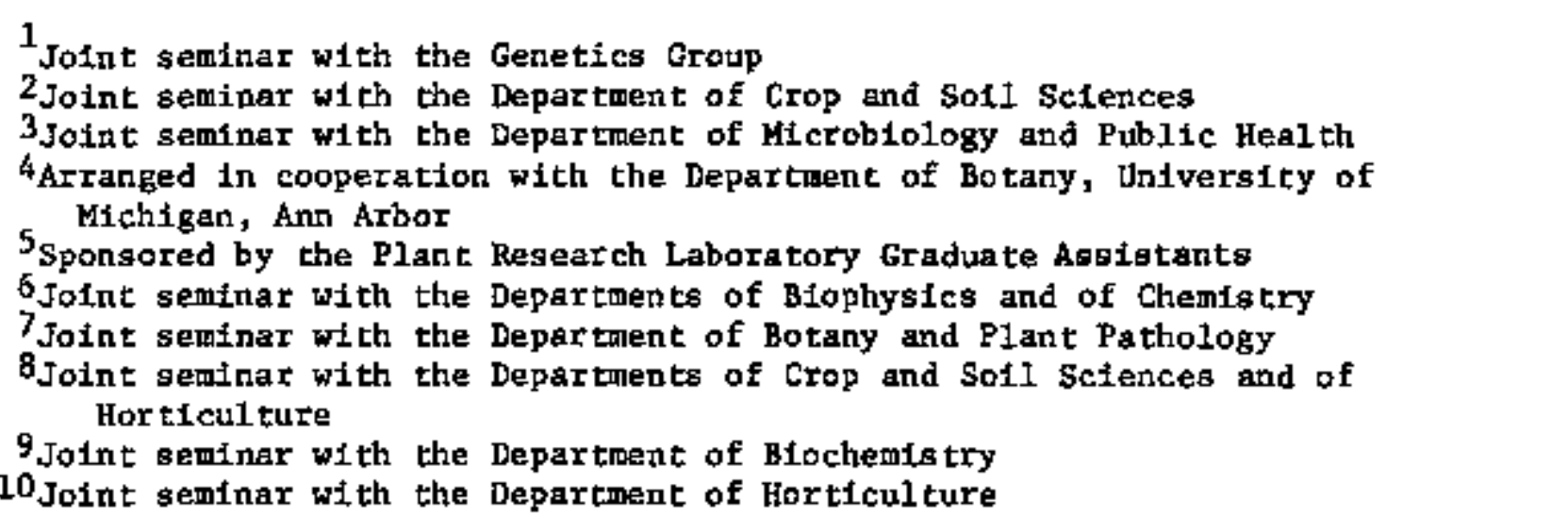 } \\
\hline
\end{tabular}


RESEARCH REFORTS

The following reports, dealing with work much of which Lis still in progress, are not intended as publications, and should not be cited without spectfic peralssion by the responstble Investigator. 
STOMATAL. REGULATION OF THE GAS EXGHANGE

BETWEEN PLANT AND ENVIRONMENT

This project deals with the regulation of $\mathrm{CO}_{2}$ uptake and water-vapor loss of plants by the stomata. Virtually all the carbon dioxide taken up by planta during the conversion of solar energy into cheolcal energy passes through the stomata; almost three-quarters of the vater precipitated on the cerrestrial $\mathrm{b}$. S. returns to the atmosphere through stomata. The stomatal control systen responds, through the action of several feedback loops, to enviromental factors $\left(\mathrm{Co}_{2}\right.$, humidity, 1ight, temperature, pollutants) and to physiological factors within the plant (the intercellular $\mathrm{CO}_{2}$ concentration, water potential, concentration of abscisic acid, a plant hortmone formed rap1dly under stress). We are attempting to determine functions which describe the responses of the couponents of the feedback system to the above loputs, and by applying phystcal and blochenical principles and methods we hope to gain an understanding of the underlying phystological mechanisms of stomatal regulation.

Stomata are rarely, if ever, in a steady state in the fleld. The stomatal control mechanisms are not homeostatic; the opposing priorities of increased assimilation and decreased transpiration see to that. We have begun to develop tools to study stomatal function while otomata move, and to measure stomatal performance. The firgt three of the following contributions report on such tools and their use, while the last thiee report on groundwork necessary to identify the blochemical transducer and effector mechantsms in guard cells.

\section{Computer Control of Air-Condittoning and Gas Analysis System}

G. D. Farquhar, D. Pht1lips, T. D. Sharkey, K. Raschke

Measurement of plant enviroment and performance requires facilfties for accurate measurement, multiple, fast coaputations and display of data. We require the results of these computations eved as the plant is responding, and an on-line minicomputer is the simplest means of achieving this. Last year ve reported plans for interfacing a mintcomputer to our gas analysis system (Plant Research 74, p. 34). We have now written the necessary "drivers", 
programs necessary for interfacing the computer to its peripherals, and the programs required for calibration of equipment and Imtediate display of data. Computer control of the alr-conditioning and gas analysis system Is now used routinely.

We have also rodified equipment and written prograns that allow us to perturb the leaf environment in predetermined fashions. The humidity of the air can be varied by varying the temperature of water flowing through the jacket of a condenser. The computer determines the mixing ratio of hot and cold water in this flow. This has enabled us, as planned, to break the feedback loop involving transpiration, by compensating changes due to stonatal aperture with changes in ambient humidity. Maintenance of constant transpiration contributes to a reduction In the atrbiguity associated with experiments on stonata. We have also written a prograti that ptoduces sinusoidal variations in the lunidity of the air passing over a leaf. A modification of this program changes humidity in a manner that evaporation now follows a sinusoldal trace.

2. Quantitative Eramewotk for the Study of the Effects of Stress on Feedback Logps Involving Stomata

\section{G. D. Farquhar}

The degree to which stomata affect the fluxes of $\mathrm{CO}_{2}$ to the leaf and water and sensible heat from the leaf depends on the environment imposed on those stomata. For example, in an atmosphere with a high ambtent concentration of $\mathrm{CO}_{2}$, a small change in stomatal conductance gives rise to a larger change in the influx of $\mathrm{CO}_{2}$ than in an enviroment in which the $\left[\mathrm{CO}_{2}\right]$ is low. Extending the notion of stomatal envicoment to fnclude the photosynthetic tissue, we also know that in an enviroment in which efficient $\mathrm{Co}_{2}$ fixation is occturring (e.g. plants with the $C_{4}$ pathway) a sala11 change in stomatal conductance gives rise to a bigger change in the influx of $\mathrm{Co}_{2}$ than does an 'inefficient' environdent. The sensitivity of the flux of water vapor to changes in stomatal conductance, $\frac{\mathrm{dE}}{\mathrm{dg}}$, has been termed "environmental gain". An analogous concept exists for the flux of $\mathrm{CO}_{2}$ but one can chose to divide the $\mathrm{CO}_{2}$ feedback toop silghtly differentiy and to call the sensitivity, $\frac{\mathrm{dC}_{i}}{\mathrm{dg}}$, of the concentration of $\mathrm{CO}_{2}$ inside the lea $\mathrm{F}, \mathrm{C}_{\mathrm{I}}$, to changes in stomatal conductance the enviromental gain. The remaining halves of the $\mathrm{CO}_{2}$ feedback loops iavolving water and $\mathrm{CO}_{2}$ are the sensltivities of stomatal conductance to small changes in evaporation rate and internal $\left[\mathrm{CO}_{2}\right]$, respectively. 
The sensittvities, $\left.\frac{d g}{d E}\right)_{C_{i}}$ and $\left.\frac{d g}{d C_{1}}\right)_{E}$ depend on the physlology of the stomata and are calted phystologtcal gains.

The dimensionless product of an environmental and a physlological gain is called a loop gain, $G$. Its magnitude is a measure of the importance of that loop and is a weasure of what happens to a disturbance traveling axound the loop. A positive loop gatn deans that positive feedback is occurring and a negatlve loop gain means that negative feedback is occurring. Consider a disturbance which would cause a change, $n$, in atomatal conductance if acting alone, 1.e., with the feedback loop inactivated. It may be shown simply that the change in conductance that accurs in the presence of $a$ feedback loop, with a loop gain $G$, is $\frac{\pi}{1-G}$. Thus with a loop gain of -1 (negative feedback) the effect of an external disturbance is halved. The Inop gain should also affect the speed of storatal responses and the stability af the syster.

The notion of phystological gain may be extended to include the time dependence of transient physiological processes. The phystological transfer function is the ratio of the Laplace transformstions of the stowatal response to the small perturbation of $\mathrm{flux}$ (or $\mathrm{C}_{1}$ tn the case of $\mathrm{CO}_{2}$ ). Knowing the physiological transfer functions, the stopatal responses to arbitrary (small) environtmental perturbatlons can be predicted.

There is evidence that the hydraulic phystological transfer function is of third order,

$$
\begin{aligned}
& \text { i.e. } \bar{g} / \bar{E}=H_{0} \frac{\left(1-\mathrm{s \tau}_{1}\right)}{\left(1-\mathrm{s \tau} \tau_{3}\right)\left(1+\mathrm{s} \tau_{1}\right)}\left(\overline{\left.\mathrm{s} \tau_{4}\right)\left(1-\mathrm{s \tau _{5 }}\right)}\right. \\
& \text { where } \quad \overrightarrow{8}=\int_{0}^{\infty} e^{-s t}\left(B-g_{0}\right) d t \text { and } g \text { is stomatal conductance } \\
& \bar{E}=\int_{0}^{\infty} e^{-s t}\left(E-E\left(g_{0}\right)\right) d t \text { and } E \text { is evaporation rate }
\end{aligned}
$$

$s$ is the Laplace operator, and the $\tau_{1}$ are time constants. To convert this to state space vartable notation

$$
\dot{\mathbf{x}}=\mathrm{Ax}+\mathrm{Bu}
$$

where $x$ is the state of the system, $u$ is the control vector, A is the systen matrix and $B$ is the assoclated matrix of the 1nput vector; we note that if $h$ is the effective boundary layer conductance and $p$ is the evaporation potential 


$$
\begin{aligned}
& E=\frac{g h_{p}}{g+h} \\
& \bar{E}=\frac{\partial E}{\partial p} \bar{p}+\frac{\partial E}{\partial g} \bar{g}
\end{aligned}
$$

The form (2) is achieved by taking the inverse transforms of Eqs (1) and (3), combining thet and putting

$$
\begin{aligned}
& x=(g \dot{g} \dot{g})^{T} \\
& u=(p \dot{p} \beta)^{T}
\end{aligned}
$$

The responses of stomata to perturbations of the $\mathrm{CO}_{2}$ feedback loop can be described in a sinilar manner, with the control vector depending on changes of light intensity or of concentrations of $\mathrm{CO}_{2}$ in the ambient alr.

These two loops may also be combined using state and control vectors of greater dimension.

Using state space variables notation single, a $\mathrm{n}^{\text {th }}$ order system is then reduced to $n$ first order equations, which expedites analysis using digital computers. The main advantage, however, is that it allows the solution of certain problems of optima1 control. For examp1e, one could ask, in the language of optimal control: "Knowing the system and associated matrices, $A$ and $B$, and choosing as an index of performance, $J$, the time taken to move from one state (conductance) to another, what controls (humidity and $\left[\mathrm{CO}_{2}\right]$ ) should be Implemented to mininize $\mathrm{J}$ ?"

The more fundamental problen is the irverse problem (Kalman, 1964). Knowing the control laws, what index of performance is being minimized? The challenge is to choose a state vector, depending on assimilation and transpiration and perheps conductance itself, use control laws related to the transfer functions and determine what aspects of this summary of dynamic plant behaviour are being optimized. The work is continuing in order to solve this problem.

\section{Reference}

Kalman, R. E., Trans. ASME, J. Bagic Eng., 86:51 (1964) 
3. Measurement of $\mathrm{CO}_{2}$ koop Gains and the Effects of Abscigic Acid on these Gaing

D. Dubbe, G. D. Farquhar, K. Raschke

A key process in the response of plants to many different kinds of stress is the production of abscisic acid. It was reported earlfer (Plant Research 173, p. 25) that Increased leve1s of ABA increase the sensitivity of stomata of Xanthiwn stmumarion to $\left[\mathrm{CO}_{2}\right]$ (1.e. the magnitude of the physiological gain is increased). We have commenced studies using the prevlously outIined approsch and measured the environmental, phystological and loop gains of the $\mathrm{CO}_{2}$ feedback loops in three spectes, Gossypium hirsutum (cotton), Xanthium stmumariom (cocklebur), and Zea mays (corn), with and without the addition of $( \pm$ )-ABA (akin to stressed and non-stressed planta respectively).

In each case the leaf temperature was held at about $23 \mathrm{C}$ while the dewpoint of the air was $18 \mathrm{C}$, yielding a small environmental galn of the feedback loop associated with water. Together with the use of detached leaves this thinimized the hydraulic feedback. The quantum fiux dengity was $130 \mathrm{nE} \mathrm{cm}^{-2} \mathrm{~s}^{-1}$.

Some data for $X$. strumariun are shown in Fig. 1. The conductance to diffusion of vapor is that of the leaf in serles with its boundary layer. In graphs $A$ and $B$ the physlologtcal and environmental gains are given by the slopes of the curves. The appropriate operating points are the intersections of these curves, as shown In graphs $C$ and $D$, where the 'environmental response' has been replotted as Independent vs. dependent variable. The 1oop gain is then the product of the slope of the phystological response curve and the inverse slope of the replotted environmental response. Values for these various galns are given in Table 1 .

The addition of ( \pm )-ABA to the Irrigation water resulted in an increase in the magnitudes of all three gains for Xanthizm strumarium and Gogstypizm hirautim, the loop galns changing from zero to -0.5 and -1.0 , respectively, with notmal ambient $\mathrm{CO}_{2}$ concentrations. Zea mays has a high loop gain of -1.0 in the absence of ( \pm )-ABA. The increases in the envirommental gains resulted from stomatal closure and not from direct effects on photosynthesis. We conclude that the $\mathrm{CO}_{2}$ control loop $1 \mathrm{~g}$ unimportant in unstressed Xanthion and Gossypium, but Important when these species are 

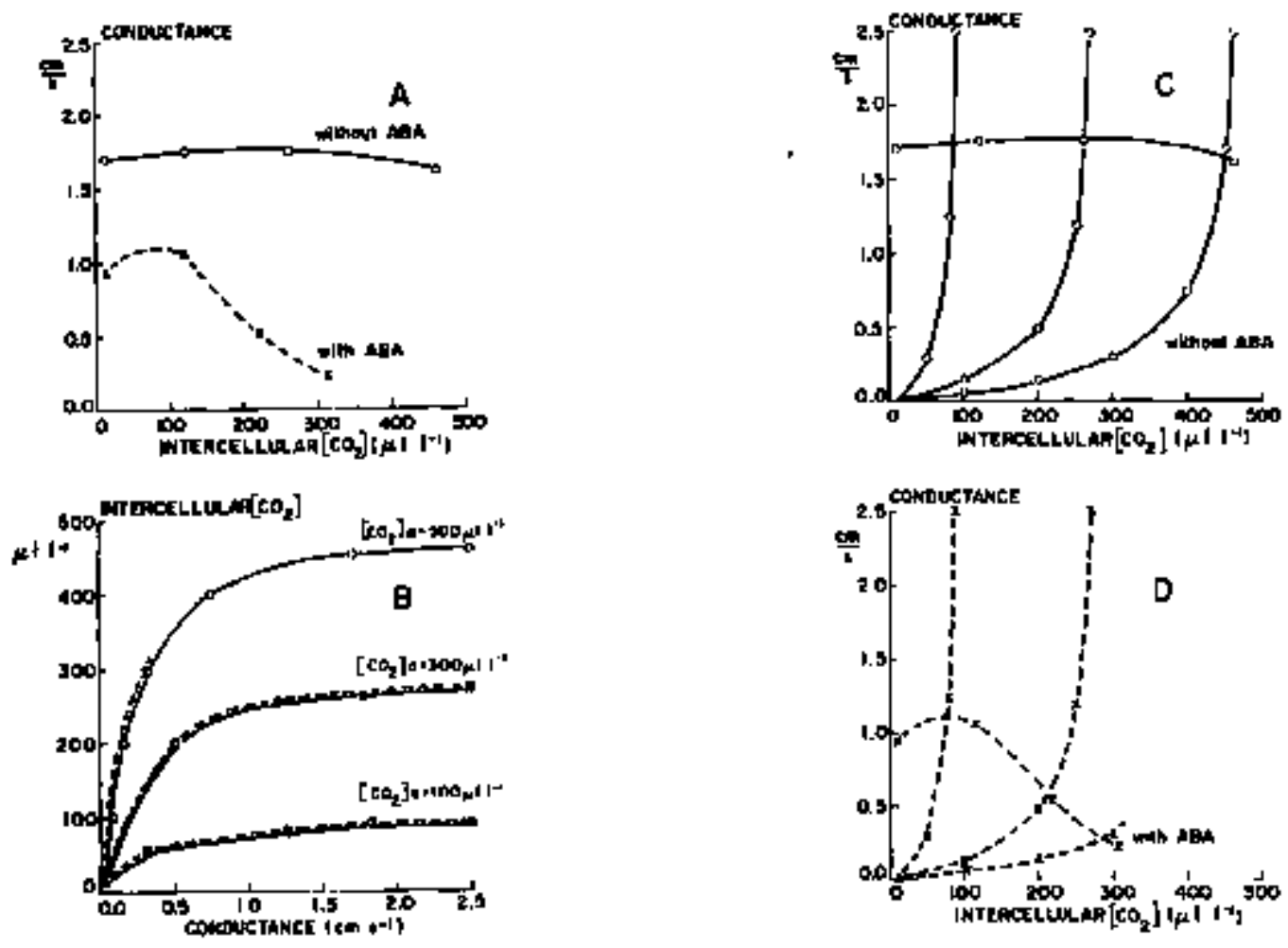

Fig. 1. A indicates the physiological response of the stomata of Xanthium strumarizom in the absence (solid line) and presence (dashed line) of $10^{-5}$ $M( \pm)-A B A$ in the firlgation water of leaves with trimmed lamina. B indicates the dependence of intercellular $\left[\mathrm{CO}_{2}\right]$ on conductance at various ambient $\mathrm{CO}_{2}$ concentrations, calculated from the diffusion equation and the photosynthetic response curves. In $C$ and $D$ the physiological and "environmental" curves are superimposed to find appropriate operating points. 
Table 1. Values for the physiological, environmental and total loop gains in Xanthium etromari,un, Cossypizm hireutum, and Zea maye at an anbient $\left[\mathrm{CO}_{2}\right]$ of 300 us $\mathrm{e}^{-1}$.

\begin{tabular}{|c|c|c|c|c|}
\hline & $\begin{array}{l}A B A \\
\text { added }(d)\end{array}$ & $\begin{array}{l}\text { Physiological } \\
\text { gain } \\
\text { cm } s^{-1}\left(\mu k^{-1}\right)^{-1}\end{array}$ & $\begin{array}{l}\text { Environmental } \\
\text { gain } \\
\left.\text { s cm-I (ul } t^{-1}\right)\end{array}$ & $\begin{array}{l}\text { loop } \\
\text { gatn }\end{array}$ \\
\hline Xanthiwn & $\bar{y}$ & $\begin{array}{c}0 \\
-0.005\end{array}$ & $\begin{array}{l}16.7 \\
100\end{array}$ & $\begin{array}{c}0 \\
-0.50\end{array}$ \\
\hline Gossypium & - & $\begin{array}{l}-0.0001 \\
-0.002\end{array}$ & $\begin{array}{l}100 \\
500\end{array}$ & $\begin{array}{l}-0.01 \\
-1.00\end{array}$ \\
\hline $2 e \alpha$ & - & -0.0025 & 417 & -1.04 \\
\hline
\end{tabular}

stressed and 1mportant in Zea all the time. We conclude further that in Zea and in Gossypiwt leaves supplied with $10^{-5} \mathrm{H}( \pm)-\Lambda B A$, the Intrinsic responses to external perturbations appear halved by the action of the $\mathrm{CO}_{2}$ feedback loop.

4. Contro1 of Stomata Aperture in Leaves by Abacisic Ac1d (ABA); Depeadence on Transplration Rate, Prescntation Time, and Temperature

T. D. Sharkey, K. Raschke

This was in continuation of a study in the time lags of stomatal responses to ( \pm ) $\mathrm{ABA}$ and in the quantities of this messenger substance needed to ellcit a stomatal response (Plant Research '74, p. 25-28). As before, the delay between the addition of ABA to the Irrigation water of detached leaves and a $5 X$ reduction in stomatal conductance wag measured and the amount of ( ()$-A B A$ was determined which during this time had entered the leaf tissue. This anount was called the $5 \%$ dose. In all three species

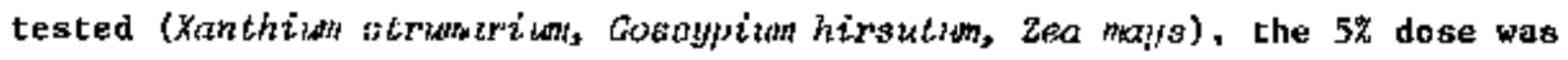
found to have been independent of the rate of solutfon uptake (= transpiration rate), a1though the latter was varted up to threefold. There were, however, differences in the $5 \%$ doses between spectes and between teaves of different ages. After application of $10^{-5} \mathrm{M}( \pm)-A B A$ the $5 \%$ doses were (in pmole $( \pm)-A B A$ per $\mathrm{cm}^{2}$ leaf lamina): K. etmumarium, 98; G. hirsutum, 43; 2. mays, 17; young Ieaves of 6. hixsutum, 30 . We do not yet know, whether these differences In the 57 doses were caused by differences in leaf anatony or had another cause. 
If ( \pm )-ABA was presented for limited times only, smaljor doses than the $5 \%$ doses were sufficient to produce (transient) stomatal closing movements. Presentation of $10^{-5} \mathrm{M}(1)-\mathrm{ABA}$ for 5,10 , and $15 \mathrm{~min}$ to leaves of $X$. Btmanarium reduced the triggering doses to 22,45 , and 72 pmoles $\mathrm{cm}^{-2}$, respectively. In theory, pulses of ABA sent out hy the mesophyll would, therefore, suffice to signal water stress to the guard cells; continuous supply of ABA would not be required for lile stomatal poderation of water loss.

The temperature dependence, if any, of stomatal. responscs to ABA was thought to indicate whether the magnitude of lisse responses was determined predominantly by phystcal processes (1tke adsorption) or metabolic ones. Five-percent doses were determinud for all three species at 15, 20, and $25 \mathrm{c}$ leaf temperature. Transpiration rates were kept equal at all temperature levels by adjusting the moisture content of the air. In $\mathrm{CO}_{2}$ containing air $\left(300 \mathrm{ul} \mathrm{l}^{-1}\right)$ the $5 \%$ doses incrased slightly with temperature in $X$. strumzinm, and decreased slighty in $G$. hiscutim. In $\mathrm{CO}_{2}$-Free air, the $5 \%$ doses were larger in both species and they declincd with cemperature in either. We ascrtbe this enhanectment by tomperature of the effect of $\left( \pm>-A B A\right.$ to the increasing evolution of $\mathrm{CO}_{2}$ with increasing temperature. Between 15 and $25 \mathrm{C}$, respiration of leaves of $X$. strumarium increased 20-fold, that of G. hirsutum 3-fold. We know from earlier experiments (Plant Research '73, p. 25-28) that $\mathrm{CO}_{2}$ entances the effect of $A B A$ on guard cells. There was hardly any influence of terperature on the response of maize stomata to ABA. At al1 tenperatures between 15 and $25 C$ the $5 \%$ doses were smaller in the presence of $300 \mu \mathrm{CO}_{2} e^{-1}$ than $1 \mathrm{n} \mathrm{CO}_{2}$-free air. At $\mathrm{l}, 5 \mathrm{C}$, the dase was $1 / 2$ of that in $\mathrm{CO}_{2}$-free air; at $25 \mathrm{C}$, it was $<1 / 3$. We concluded (a) that the temperature dependence of stonatal responses to ( $t)-A B A$ was small in the three spectes tested, (b) that the $5 \%$ dose declined with the increase in the $\mathrm{CO}_{2}$ content of the alr (confirming and extending earlier results), and (c) that $\mathrm{CO}_{2}$ evolved by the leaf tissue during respiration enhanced the action of ( \pm )-ABA on guard cells. 
5. Synthesis and Metabolism of Malate In Epldermal Tissue*

(a) Assimilation of $\mathrm{CO}_{\mathrm{g}}$ by Epidermes

K. Raschke; P. Dittrich (Untversity of Munich, Gerplany)

Th1s Investigation was conducted to answer two questions: (i) Is [carbon-4] of malate in guard cella derived from $\mathrm{CO}_{2}$ ? (ii) Are guard ce11a able to $\mathrm{fix} \mathrm{CO}_{2}$ at all times, or only during stomatal opening? If $\mathrm{CO}_{2}{ }^{1 s}$ f1xed independently from the state of stonatal aperture, then the rate of malate formation could be used by the guard cells to sense the $\mathrm{CO}_{2}$ concentration in the air (Raschke, 1975).

Eptdermes were pulled off leaves of Commina commis and Tutipa gesnemiana and cleaned from debris of the mesophyll (using a microscope for inspection). Then the epldermal samples were exposed to ${ }^{14} \mathrm{CO}_{2}$ in the gas phase. After varlous periods of exposure the eptdermal samples were kilied and extracted, and the residue was hydrolyzed. Extracts and hydrolysates were chromatographed after Basshan and Calvin. Autoradiograms of the chronatograms were evatuated, following conventional procedures.

Isolated eptdermes of Commetina commanis and tulipa gesneriana assimilated ${ }^{14} \mathrm{CO}_{2}$ in the dark as well as in the light, whether stomata were open or closed (F1g. 2). In all cases, the maln assimflation products were malic and aspartic acids. Both aclds together accounted for more than 90\% of the assimilated radioactive carbon. Phosphoglycerfc acid appeared in the 1ight only in tullp epfdermis, but contained even iu this case less than $2 \%$ of the label. The sane was true for sugar phosphates; no sugar phosphates occurred in ep1dermal tissue of Commelina (Table 1). Guard cells of C. commuris and $T$. gesnemiana therefore do not

*This work was performed during K,R.'s sabbatical leave at the Botanfsches Institut der Untversitït München, Germany. 
Tulip epidernis. Fixotion of $\mathrm{K} \mathrm{CO}_{2}$ for 30 sec.

\% of absorted label

IghI

\begin{tabular}{|c|c|c|}
\hline 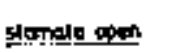 & $6000 \mathrm{npm} \mathrm{em}^{-2}$ & 300 cpm enn" \\
\hline PQA & o & 0 \\
\hline intogte & 䅦 & p. \\
\hline maldif osparlate & $\omega$ & E. \\
\hline thatriate & $\%$ & o \\
\hline scomete clased & 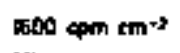 & J300 tpm tm-1 \\
\hline Pan & ex & 0 \\
\hline atpite & $m$ & $\mathbf{t}^{2 / 4}$ \\
\hline malater a aperilat & & \\
\hline futamalit & 177 & 94 \\
\hline
\end{tabular}

F1g. 2. Products of $\mathrm{CO}_{2}$ Iixation by epideralal tissue.

Table 1. Assimilation of $\mathrm{CO}_{2}$ by isolated epidermis of commitina compmits. Stomata open.

\begin{tabular}{|c|c|c|c|c|}
\hline \multirow{2}{*}{ Tlme of exposure (min) } & \multicolumn{2}{|c|}{15} & \multicolumn{2}{|c|}{90} \\
\hline & 1ight & dark & light & dark \\
\hline \multicolumn{5}{|l|}{ Radioactivity $\left(\mathrm{cpm} \mathrm{cm}^{-2}\right)$} \\
\hline $\begin{array}{l}\text { Tatal } \\
\text { Hydrolyzable residue }\end{array}$ & $\begin{array}{r}760 \\
0\end{array}$ & $\begin{array}{r}960 \\
0\end{array}$ & $\begin{array}{r}4,440 \\
0\end{array}$ & $\begin{array}{r}2,530 \\
50\end{array}$ \\
\hline \multicolumn{5}{|l|}{$\begin{array}{l}\text { Radioactivity } \\
(\% \text { of soluble fraction) }\end{array}$} \\
\hline Malate & 70 & 58 & 49 & 62 \\
\hline Aspartate & 24 & 23 & 22 & 18 \\
\hline Citrate & 6 & 6 & 5 & 6 \\
\hline Fungrate & 0 & 0 & 1 & 1 \\
\hline Ser, gly & 0 & 0 & 20 & 10 \\
\hline Glutamate & 0 & 13 & 2 & 2 \\
\hline Sugar phosphates & 0 & 0 & 0 & 0 \\
\hline Glucose & 0 & 0 & 0 & 0 \\
\hline Sucrose & 0 & 0 & 0 & 0 \\
\hline
\end{tabular}

1 yitelded only glutose 
possess the reductive phosphate patiway; if it exists, 1t is only rudimentary. (The sma11 amounts of phosphoglyceric actd occurring in tulip epidermis may have been because of contanination with a few mesophylI chIoroplasts). Epidermes of both species were however in any physiological state able to incorporate ${ }^{14} \mathrm{CO}_{2}$ into malate. During the past 20 years it has been demonstrated repeatedly by autoradiography that the ability of the epidermis to assimilate $\mathrm{CO}_{2}$ rusfdes in the gun cells.

\section{Reference}

Raschke, K., PIanta 125,243 (1975)

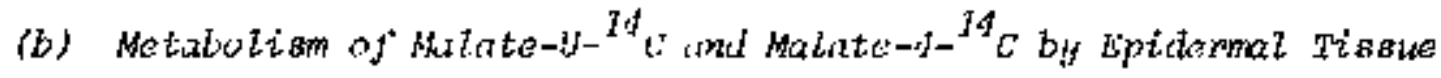

X. Raschke; P. Bittrich (Untversity of Munich, Germany)

After stomatal closure, usually starch reappears in guard cells.

It is likely that gluconeogenesis occurs in guard cells. This possibility was cested by foeding labelled malute to epldernal strips and following

the appoarance of radioactivity in other acids and carbohydrates.

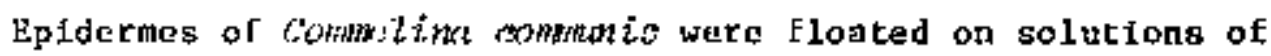

labeled Nislate. 'lhe laryest portion of malate taken up by epidermes was fourd to remain malate $(60 \ldots 85 \%)$. A smaller portion appeared in the citric acid cycle and was partially transaminated. When unfformiy malate was offered, radioactivity was found in carbohydrates (glucose, fructose, sucrose). This was not obscrved after feeding malate the 4-C of which was the only labeled one (1ables 1,2).

Only traces of radiouctivity were found in sugar. Epidermal cells, and In particular guard culls, are thereforc able to perform gluconeogenesis. The slight radioactvity of the sugars observed after the application of 4-C-labeled mata can he explained as resulting from an equilibration between malate and fumarate during which some label moved from position 4 to position 1. Labtel In position 1 was, of course, not lost during decarboxylation of malate, and carried into the carbohydrates.

The appearance of radioactivity in sugars as well as in citrate indicates that during stomatal closure part of the malate is converted into sugar, another part is burnt up. 
Table 1. Metabolism of malate in epidermis of Commelina commonio In darkness. (Percent of total activity).

\begin{tabular}{|c|c|c|c|c|c|c|}
\hline \multirow[b]{2}{*}{$\begin{array}{l}\text { Exposure ( } \mathrm{min} \text { ) } \\
\text { Radioactivity (cpra } \mathrm{cm}^{-2} \text { ) }\end{array}$} & \multicolumn{3}{|c|}{ Malate- $\mathrm{II}-{ }^{14} \mathrm{C}$} & \multicolumn{3}{|c|}{ Malate-4- ${ }^{14} \mathrm{C}$} \\
\hline & $\begin{array}{r}10 \\
1,240\end{array}$ & $\begin{array}{r}30 \\
1,610\end{array}$ & $\begin{array}{r}120 \\
3,470\end{array}$ & $\begin{array}{r}10 \\
25,100\end{array}$ & $\begin{array}{r}30 \\
13,500\end{array}$ & $\begin{array}{r}120 \\
17.420\end{array}$ \\
\hline Malate & 91 & 84 & 61 & 96 & 95 & 86 \\
\hline Aspartate & 2 & 2 & 4 & 0.3 & 0.5 & 0.9 \\
\hline Citrate & 7 & 6 & 4 & 2 & 3 & 6 \\
\hline Glucose & 0 & 0 & 6 & 0 & 0 & 0 \\
\hline Fructose & 0 & 0 & 5 & 0 & 0 & 0 \\
\hline Sucrose & 0 & 0 & 14 & 0 & 0 & 0 \\
\hline Hydrolyzable residue & $I$ & $<1$ & 2 & 0 & 0 & 0.6 \\
\hline
\end{tabular}

Table 2. Metabollem of malate in epldermis of Commelina commonis in the Iight. (Percent of total activity).

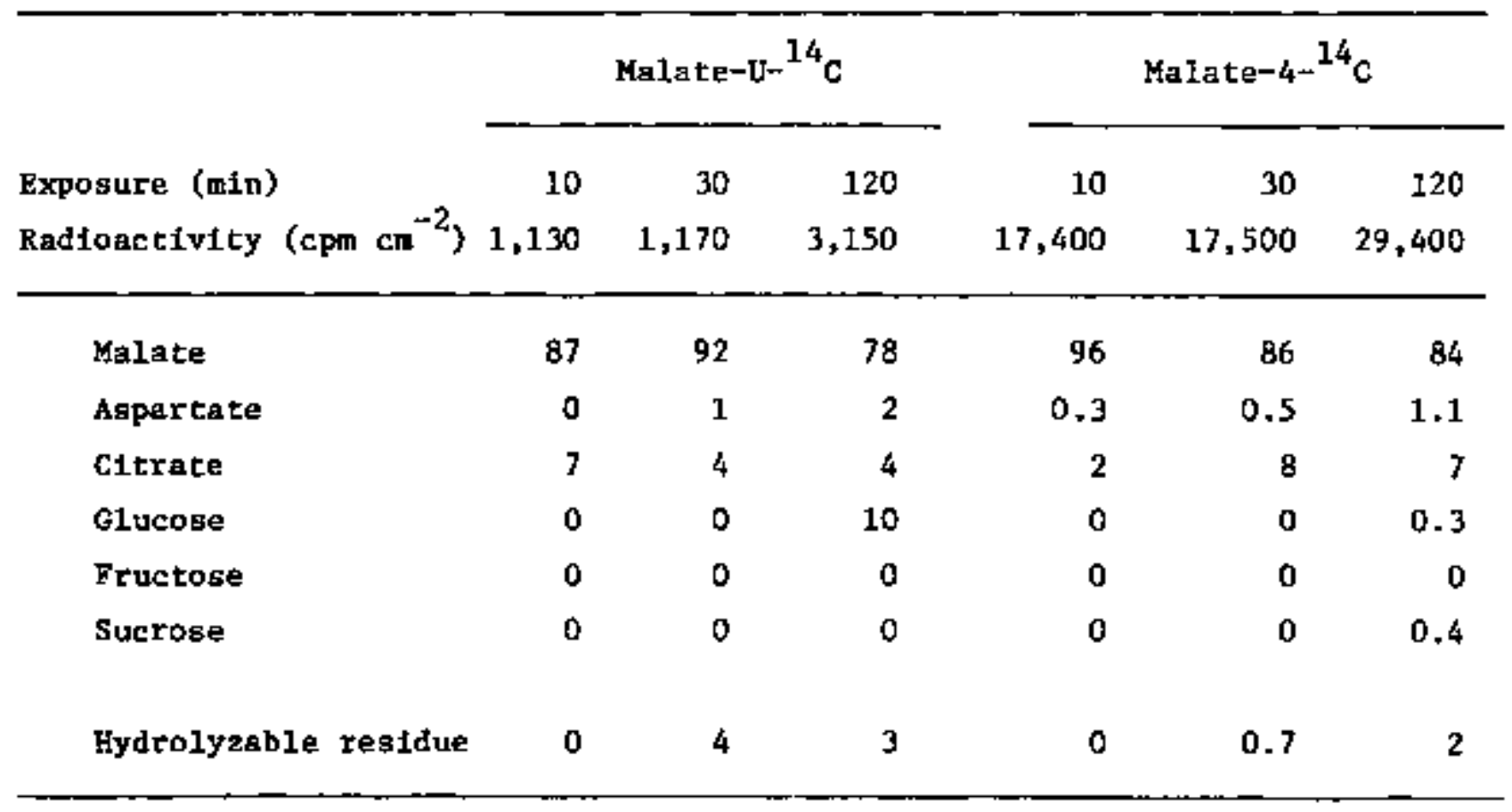


6. Jptake and Netabo1ism by Epidernal Tissue of Radioactively Labeled Carbohydrates

P. Dittrich (University of Munich, Germany); K. Raschke

It is wel1-known that, In general, starch disappears from the chloroplasts of guard cells during stomatal opening. Most probably, starch and sugar supply carbon-1 through -3 of the malic actd which is required to take up $\mathrm{K}^{+}$ and balance the positive charges of $\mathrm{k}^{+}$. This work was conducted to see whether the radioactivity of labeled carbohydrates offered to guard cells would appear in malate. At the same time, the experiments would provide a teat whether guard cells are able to use assimilates of the mesophy 1 to xeplenisl their carbon (and posstbly encrgy) resources. He showed in a preceding report ( $p .36$ ) that guard cells appear to be unable to fix $\mathrm{CO}_{2}$ photosynthetically. ${ }^{14} \mathrm{C}$-labeled glucose, glucose-1-phosphete (G-1-P), sucrose and maltose were offered to epidermal strips of Commetina communis and Thitipa gesneviana in concentrations between $40 \mathrm{uM}$ and $10 \mathrm{mll}$. The uptake rates varied between $4 \times 10^{-11}$ mole $\mathrm{cm}^{-2} \mathrm{~h}^{-1}$ (from a $40 \mu \mathrm{M}$ solution of sucrose) and $4 \times 10^{-8}$ mole $\mathrm{cm}^{-2} \mathrm{~h}^{-1}$ (from a $40 \mu \mathrm{M}$ solution of sucrose) and $4 \times 10^{-8}$ mole $\mathrm{cm}^{-2} \mathrm{~h}^{-1}$ (From a 10 mat solution of G-1-P). These cates were equivalent to $10^{-14}$ to $10^{-11}$ mole stoma $\mathrm{h}^{-1}$, If al1 label taken up was accunulated in the guard cells. The carbohydrates taken up were metabolized rapidly in the light as well as in darkness; the resulting labeling pattern was very simflar to that obtained by green leaf tissue after a short perind of photosynthesis: label appeared in sucrose, glucose, fructose, maltose and in sugar phosphates (an example 15 gIven in Table 1). Two hours after tho exposure to the labeled carbohydrates the relative intensity of labeling of malate began to increase. A pulse of 1 hr duration of ${ }^{14} \mathrm{C}-\mathrm{G}-1-\mathrm{P}$ chased by 1 hour 12 C-G-1-P forced tip to $42 \%$ of the inftially absorbed label into malate. Overnight, up to $82 \%$ of the label was directed into the insoluble fraction. Hydrolysis resulted in glucose only, indicating formation of starch (which could also be shown histochemlcally). Strong formation of starch was observed also af ter feeding glucose, sucrose, and maltose.

\footnotetext{
*Th1s work was performed during K.R.'s sabbatical leave at the
} Botanisches Institut des Universität Munchen, Germany. 
Table 1. Metabotism of ${ }^{14} \mathrm{C}$-labeled sugars by epicermal tissues after 4 hourg of Incubation in darkness, stomata originally open. (Percent of radioactivity in epidermal safiple).

\begin{tabular}{|c|c|c|c|c|}
\hline \multirow[b]{2}{*}{ Netabolite } & \multicolumn{2}{|c|}{ Glucose } & \multirow{2}{*}{$\begin{array}{l}\text { Sucrose } \\
\text { C. commonis }\end{array}$} & \multirow{2}{*}{$\begin{array}{l}\text { Maltose } \\
\text { C. comatios }\end{array}$} \\
\hline & C. commonis & T. gesnemiana & & \\
\hline Starch & 81 & 47 & 62 & 34 \\
\hline GIucose & 6 & 2 & 10 & 2 \\
\hline Stucrose & 2 & 8 & 14 & 2 \\
\hline Maltose & 0 & 0 & 1 & 40 \\
\hline Mal, asp & 2 & 31 & 2 & 6 \\
\hline $\begin{array}{l}\text { Citrle eyele } \\
\text { actds }\end{array}$ & 1 & 1 & 1 & 4 \\
\hline $\begin{array}{l}\text { Sugar phos- } \\
\text { phates }\end{array}$ & 1 & 1 & 3 & 2 \\
\hline
\end{tabular}

It was thought possible that not only the guard cells but all epfdermal cells make starch from carbohydrates of their phosphates. In order to test this possibllity ${ }^{14} \mathrm{C}-\mathrm{G}-1-\mathrm{P}$ was fed to epidermal samples. These samples were embedded in glycol wethacrylate (after washing) and sectloned. Autoradiograms of the sections were found blackend over the guard cella only; starch formation was therefore thought to have been concentrated In the guard cells,

The epidermis of leaves is thus able to absorb agsimilation products from the mesaphyll; most probably, guard cells, fointly with the ordinary epldermal cells, "parastt1ze" on the mesophyll. Carbohydrates are belng used by the guard cells to make stakch and malate simultaneously. ${ }^{14} \mathrm{C}$ also entexs the citric-acid cycle and appears in the corresponding transamination products .

Epidermes of $C$. conmunis and $T$. gesneriona appear not to be able to perform the reductive pentose phosphate cycle, In spite of the presence of chloroplasts in the guard cells. Guard cells seem to have to depend on an import of carbohydrates from the mesophyll. This suspicion was supported by the result of the following experiment. 
Epldermal eamples of $C$. consmmis wexe exposed to ${ }^{14} \mathrm{CO}_{2}$ for $10 \mathrm{~min}$, along with whole leaves of this epectes. The ${ }^{14} \mathrm{C}$ contents of the epidermes on the leaves were then compared with those of the fsolated epjoermes. Epidermes which had renained In contact with the nesophyll contained 17 times more ${ }^{14} \mathrm{C}$ than the isolated epldermes. In a following experiment, epidermal samples were put on mesophy1] which had been sssimilating ${ }^{14} \mathrm{CO}_{2}$ for 10 min before it was brought into contact with the 1solated eptiermio. Three hourg later, mesophyll and the eplderual sample vere extracted and chromatographed. The labeling pattern of the epidermis corresponded with that of the mesophy11 (sucrose, glucose, fructose, malate, glutamate) with the exception of the share of waIate; epidermal tisgue contained, in relative terws, about twice as nuch malate as the mesophyll (22\% of the total label versus 10\%) (Table 2).

Table 2. Labeled compounds found 3 hours af ter a 10 min exposure of leaves of Commelina comonita to ${ }^{14} \mathrm{CO}_{2}$. (\% of radioactivity in ethanol extract).

\begin{tabular}{|c|c|c|c|}
\hline Compound & Mesophyll & BpldermI & $\begin{array}{l}\text { (Isolated epidermila } \\
\text { after } 90 \text { nin exposure } \\
\left.\text { to } 14 \mathrm{CO}_{2}\right)\end{array}$ \\
\hline $\begin{array}{l}\text { Sucrose } \\
\text { GLucose } \\
\text { Fructose }\end{array}$ & $\begin{array}{r}60 \\
6 \\
7\end{array}$ & $\begin{array}{r}40 \\
12 \\
4\end{array}$ & $\begin{array}{l}0 \\
0 \\
0\end{array}$ \\
\hline $\begin{array}{l}\text { DFt and sugar } \\
\text { phosphateg }\end{array}$ & $I$ & 4 & 0 \\
\hline $\begin{array}{l}\text { Malate and aspartate } \\
\text { Citric cycle acida } \\
\text { Serine and glycine }\end{array}$ & $\begin{array}{r}1 \pm \\
0 \\
0\end{array}$ & $\begin{array}{r}30 \\
5 \\
0\end{array}$ & $\begin{array}{r}72 \\
7 \\
20\end{array}$ \\
\hline
\end{tabular}


IMHIBIIORY EFFECTS IN FLOWER FORMATION

\section{Anton Lang *}

As sumnartzed, e.8., In Lang (1965), there is extensive physiological evidence supporting the Ides that flower formation is regulated by a hormonal messenger (the "floral stimulus" or "florigen") wh1ch is prodaced natnly in the leaves, and the production of which way in tuxn be regulated by certain environiental conditions, namely, low temperature (vemalization) or length of day (photoperlodigm). However, quite extensive attempts at extracting and identifying the flower horrone have so fax largely fafled. On the other hand, there 18 some evidence for the presence of flower Inhtbitory effects in plants or in Individual leaver raintained under noa-flowering conditiong. Many of these effects can be explained on the basts that the transport of the flower hormone from leaf to bud 18 tnterfered with. But in sone cases this explanation 1.6 not perticularly convinctug. Thus, Lang and Melchers (1943) showed over 30 years ago that if the leaves of the long-day plant henbare (Hyoscyomus niger) are rewoved the plant forms flowers regardless of daylength: on long days, on short days, and even in continuous darkness. 0 a the other hand, presence even of a single leaf speeds up flower formation, as compared to a defollated plant, but only if the leaf is exposed to Iong daya, whereas presence of a leaf on short days prevents flower formation as Iong as the leaf atays viable (unpublished observations). This indicates that flowering may be regulated not only by flower-pxonoting substances, but rather by an Interplay of promotive and inhibitory materiala, and this possibility was thought to deserve further exploration, since if confirmed tt would add a nev aspect to regulation of flowering.

"Conducted during a sabbatical leave at the $R$. A. Timiryazer Institute of Plant Physiology of the Acadeny of Sciences of the USSR, under the scientiflc exchange program between the National Academy of Sclences and the Acadeny of Sciences of USSR, In cooperation with Profeger M. Kh. Challaklyan, Head, Dr. I. A. Prolova, Jr. Sclentist, and other coworkers of the Institute's Laboratory of Growth and Development. 
To determine the posalbility of the existence of flower-inhibiting substances which can be translocated withtn the plant and between graft partners, grafte were made opposite to the type of grafts which provided one of the principal oupports for the exdstence of "florigen". 1.e. the flower promoting substance(s). In the latter grafts, a plant capable of flowerfig 18 grafted together with a plant that is matntained under non-flowering environmental conditiong, and it is observed whether the latter graft partner forms flowers. We grafted a non-flowerting partner onto one that was capable of flowering by Itself, and observed whether the flowering response of the latter was reduced. Ag the partner capable of flowering we used a dayceutral tobacco varlety, "Trapezond" ( $T$ ), that 1s, a plant in which flowering is largely environment-independent and occurs sponteneously once the plant reaches a certain age. As nonflowering partners, a short-day tobacco varlety, "Maryland Mammoth" (Kui) and a long-day tobacco spectes, Whootiona sylvestria (NS), were used. HM flowers on short days and daes not on long days, ws behaves in the opposito manner. The grafts with NS falled to give results, because of unfavorable conditions. The results of the grafts between $T$ and $\mathrm{kM}$ are sumparized in Table 1. The $T$ partnere flowered in all cases, flowever, when the grafte were matntained on long days, the flowering of $T$ was delayed as compared with control grafte ( $T$ on $T$ ). In contrast, when the grafts were kept on short days, that $1 \mathrm{~B}$, MH was induced to flower formation, $T$ on which fll had been grafted flowered gooner than $T-0 n-T$ controls. Thu, the results indicate that whlle a flowerfng graft partner may hasten flowering in a dayneutral partner, supporting the existence of flowerpromoting substances la plants malntalned under environmental conditions favorable for flowertig, a non-flowering partner of the game opecies and varlety may delay flowering, supporting the 1dea of transmissible flower-Inhibiting substances in planto maintalned under environmental. conditlons unfavorable for flowerlag. It must be polnted out that the differences were of marginal statistical atentficance, and the experiments will have to be repeated and expanded, Including analogous grafts between long-day and dayneutral plants. 
Table 1. Flowering response of Trapezond tobacco (T; dayneutral) in grafto with Maryland Mammoth (MM; short-day plant).

Flowering reaponse of Trapezond

\begin{tabular}{llcccc} 
Photoperiod & $\begin{array}{l}\text { Graft com- } \\
\text { blnation }\end{array}$ & $\begin{array}{l}\text { No. of } \\
\text { success- } \\
\text { ful grafts }\end{array}$ & $\begin{array}{l}\text { No. flower- } \\
\text { Ing }\end{array}$ & $\begin{array}{l}\text { Days to } \\
\text { visible } \\
\text { buds }\end{array}$ & $\begin{array}{l}\text { No. leaves } \\
\text { prior to } \\
\text { flowers }\end{array}$ \\
\hline Short day & T on T & 10 & 10 & 86 & 29 \\
& MM on T & 4 & 4 & 67 & 24 \\
Long day & T on T & 10 & 10 & 62 & 24 \\
& MM on T & 7 & 7 & 73 & 33
\end{tabular}

Prier to grafting, MM and $T$ were maintained on long days. Scions (MM on $T$ ) had ca. 5 leaves and were disbudded; stocks (T) were defollated and disbudded except for one axillary bud, and the flowering response was "read" on the side shoot developing from this bud.

\section{References}

Lang, A., Bncycl. Plant Physiol. XV/1: 1380 (1965)

Lang, A. and G. HeIchers, Planta 32:653 (1943) 
BNVIRONLFNTAL CONTROL OF PLANT GROWTH AND DEVELOPAENT THROUGA HORMONES

We are interested in control of plant growth and development by environmental factors such as photopertod and temperature. Hormones often function as intermediaries betweep perception of an environmental factor and the eventual responge (flower formation, sten growth etc.). Thus a couplete understanding of environmental effects od plants must IncIude knowledge of the nature of the hormones involved, and how their rates of blosyathegis and metabolist are controlled by the environment. We have established in earlier work that the hormone content of whole plants is usually not correlsted with the physiological response under study. He are attempting therefore to refine hormone analysis by determinting the hormonal distribution of gibberellins as well as of abscisic acld (ABA) and Its metabolites among the varlous organs and cell fractlons to see if these hormones are compartmentalized.

Since recent reports auggest that "estrogen-11ke" substances play a role in flower fornation, we have analyzed the eatrogen fraction of several plants in the vegetative and flowering stage to verify this claim. Several other sources, such as apple and date seeds, which reportedly contaln estrone, have also been analyzed. The nature of long-day inhibition of flowering in Xanthith leaves heg been studied further by correlating assimilate transport with the flowering responge.

Previous work on the role of gibberellins in stean growth and flowpr fusintion of the photoperladically sensitlve plants Bryophyliom and Silene has been continued to deternine which glbberellins are phystologlcally active In thege plants.

In most plants the young leaves and shoot tips have a much higher level of ABA, or of its netabolites, than do the mature leaves, ABA could elther be gynthesized In situ, or exported with the assintlates from the matuxe leaves. This question hag been Investigsted In Ricinug since ABA transport in this plant can be readily studied by analysis of phloem exudate. 
1. Analysis of the Estrogen-1ike Fraction In Higher Plants

L. L. L, Van Ronpuy, J. A. D. Zeevart

The general occurtence of cterosds in plants has led to the suggestion that these compounds play a hormonal role in reproduction just as they do 10 animala (Heftmann, 1975). Cholesterol, the precuraor of steroid homones, hag been found in a wide variety of plants. Furthermore, estrogene have been reported to be pregent in several plant sources (Dean et al. 1971). and the appearance of estrogen-like conpounde hag been asmoclated wht the formation of flower budg (Kopcewtcz 1971, 1972). However, eatrogens or estrogen-11ke compounds were never Identified by unamblguous criteria in any of these reports. We have therefore analyzed the fraction that would contain eatrogens fron aeveral plant soturces by gag chrongtography-nags spectrometry in order to 1dentify the compounde reportedly Involved in the flowering process.

Plant materfal was extracted with coluene and methano1, and the extract hydrolyzed with hydrochloric acid. The acidic fraction was 1solated by partitioning In aodium hydroxdde, and further purtfled and analyzed by column-, thin-Iayer-, and gas chrotatography. Extracts from the following aaurces were analyzed by mass fragnentography: shoots of Phaseolus, Ferizla and Chenopodirm, and seeds of apples (katus) and dates (Phoenix).

The belected fragmente were characteristic for sterolds containing a phanolic A ring and eaturated B, C and D ringa, Estrone, estradiol, estriol, or closely related wetabalices were not found in any of the plant courcen exantined. The detection lint of the nass fragmentographic search was datarmined by adding known ampunts of estrogens to apple seed extracts prior to analyeis. A quantity of $50 \mathrm{ng}$ of an estrogen could be detected, corresponding to a level of $\mathrm{I} .3 \mathrm{\mu g}$ estrone $/ 250 \mathrm{~g}$ apple eeeds. The reported level of $32 \mathrm{\mu g} / 250 \mathrm{~g}$ seeds (Gawienowski and Gibbs, 1969) could not be confirned.

Following Eilylation the actdic fraction was analyzed by gas chronatography. The major congtituent showed a retention time alightly longer than that of eotradiol (FIg, 1). The structure of th1s subetance was determined by mass epectrometry. Comparison of the allylated and the deuteroatiylated epectra Indicated the presence of two derivatized hydroxyl functions. The shift of $\mathrm{m} / \mathrm{e} 147$ to $\mathrm{m} / \mathrm{e} 262$ in the deuterosflylated spectrum could onty be explained by the presence of fragment $\left(\mathrm{CH}_{3}\right)_{3} \mathrm{Si}_{1-\mathrm{O}}^{+}=\mathrm{SI}_{1}\left(\mathrm{CH}_{3}\right)_{2}$, characteristlc for viclual hydroxyl groupa. The ethylene glycol structure was canfirmed by 


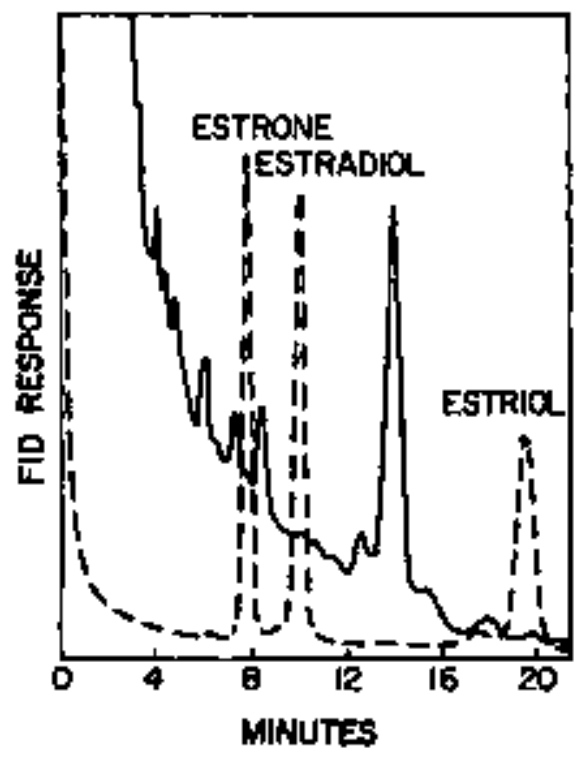

$\therefore$

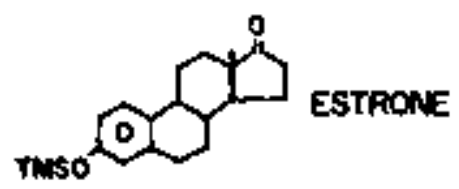

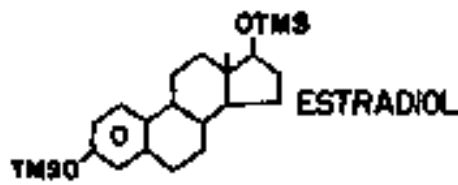

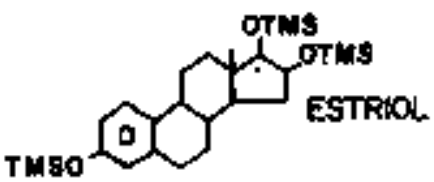

Fig. 1. Gas chromatogram of the estrogen-1ike fraction after silylation from Phreeolus, analyzed on a $37 \mathrm{SP}-2100$ column at $225^{\circ} \mathrm{C}$, isothermsl $(\longrightarrow)$ ). Superimpoed is the chromatogran of a mixtute of estrone, estradiol and eatriol, analyzed under the same conditions (-).

the formation of an acetonfde, in turn characterfzed by a prominent m/e c 101 in its nass spectrum. The molecular formula of the underivatized subatance was determined by accurate mass neasurement of the molecular fon $\left(\mathrm{a}^{+}\right.$-352) as $\mathrm{C}_{21} \mathrm{H}_{36}{ }^{\circ}$, corresponding to the monoglyceride of linoletc ac1d. In order to proof the Identity of the unknown subetance with the monoglyceride, the latter was synthesized from glycerol and 1nnolefc ac1d. 1-Monolinolentin was separated from the reaction mixture and ylelded a mass spectrum Identical with that of the unknown substance, both in the free form and as the silylether (FIB. 2). The monoglycertde of Iinolenic acid was found in Phaseolus, Perilta and Chenopoditun shoots, while the monoglycertdea of linoletc acid and of olete acid were fowod in apple seeds and date seeds, respectively. Monostearate was found in date seeds. 

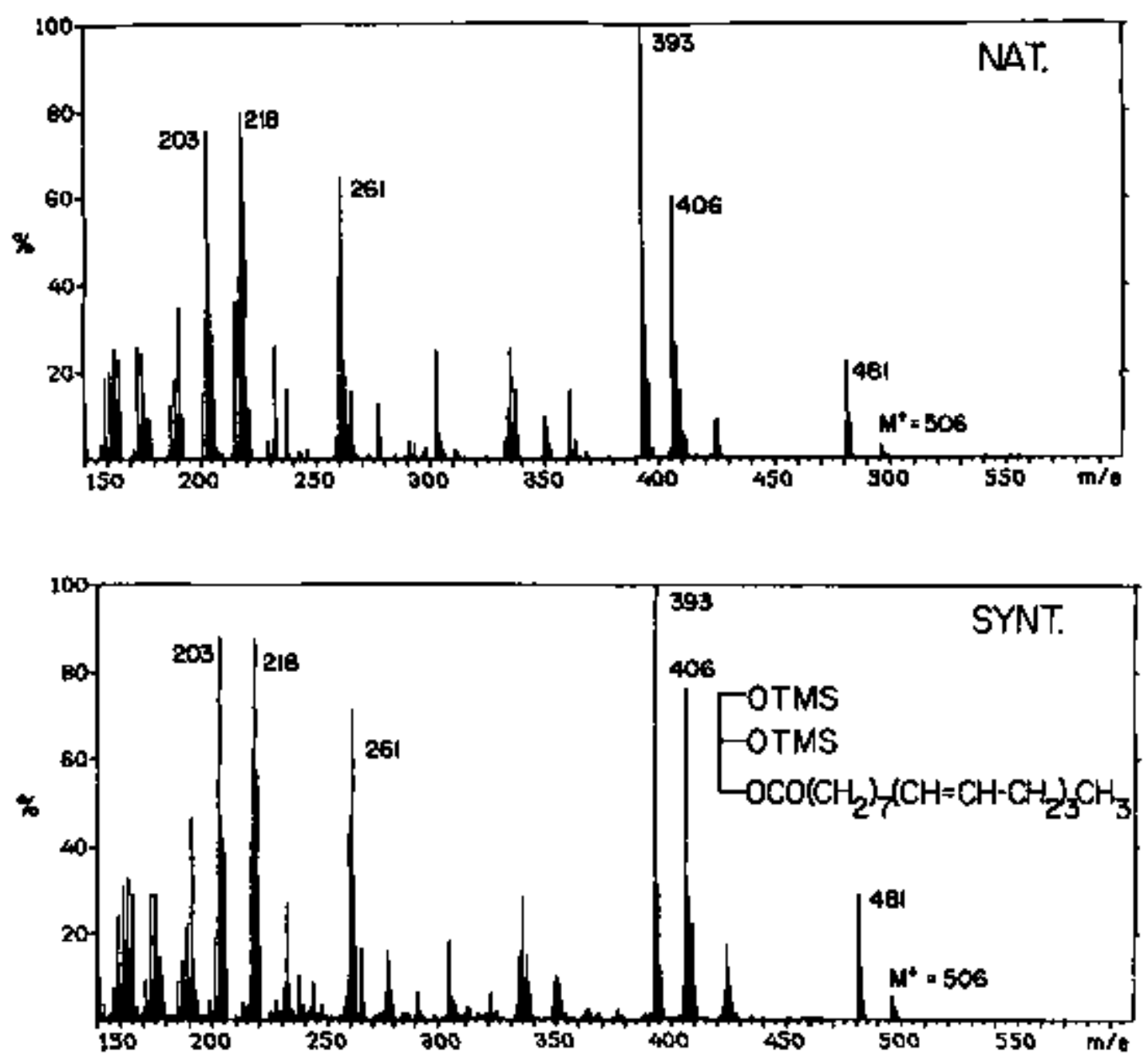

Fig. 2. Mass spectra of the syatheclc and of the natural monoglyceride of linolelc actd, 1solated from Phaesolus. The spectra vere obtained by comblned gas chromatography-mass spectrometry after silylation.

In conclusion, the occurrence of estrogens in plants remains to be demon* strated. Caution should be exerted to distingulsh estrogens from compounds such as monoglycerides that have similar chrometographic propetties.

\section{References}

Dean P., Exley D., and T., Goodwin, Phytochenistry 10:2215 (1971)

Gavtenowski A,, and C. Gibbs, Phytochemistry 8:685 (1969)

Heftmann E., Phytochemistry 14:891 (1975)

Kopcewtcz J., Phytochemistry 10:1423 (1971)

Kopcewicz J., Z. Pflanzenphystol. 67:373 (1972) 
2. Floral Inductiop and Transiocation of Labeled Assimilates in Partially Induced Xanthiton Leaves

C. Cetas, J. A. D. Zeevaart

When the tIp half of a Xanthium leaf is induced, flowering will not occur unless the basal half under LD condttions has been removed (Plant Research ' 74 , p. 45). We have continued our studies of the nature of this LD Inhibition by correlating the flowering response induced by the apical leaf half with translacation of ${ }^{14}$ Casaimilates from this induced part. Removal of the basal (non-induced) leaf half, as well as merely severing the basal part along the midrib, resulted in normal flower formation, and also significantly increaged the anount of radioactivity that accumulated in the shoot tip (Table 1). On the other hand when the Induced and non-tnduced leaf halves were separated by cutting the mesophyll perpendicular to the vildrib, no flowering resulted. In this case the labeled assimilates moved out of the aptcal half via the nidrtb as shown by autoradiography. It Is untikely therefore that the In Inhibition is due to Inactivation of the floral stimulus moving through non-Induced tessue. A more important factor appears to be export of assimilates from the basal (non-induced) leaf half: shading this part after induction of the tip had taken place, did result in flower formation.

Table 1. Translocation of ${ }^{14}$ C-assiutlates fron apleal halves of Xanthizm leaves to the shoot tips as affected by trentment of the non-labeled bagal half.

Trea tment Radioactivity per ghoot tip, $\operatorname{dap} \times 10^{-3}$

Leaf blade intact Bacal half removed

Leaf blade intact Basal half cut parallel to midrtb
41 216 
3. Flower Forpation and stem Growth in Two Strafns of Sizene armeria

J. Suttle, J. A. D. Zeevaart

Sitene armemia 18 a long-day plant which grows as a rosette under short-day (SD) conditions. Expertments were conducted with two strains obtalned from Professor S. J. Wellenstek, Agrlcułtural University, Wageningen, The Netherlands: a dwarf strain (Wellenslek, 1972), and the 1.2 ( $\Rightarrow$ late) strain (tellenstek 1973). Under our experinental condftions ( $\mathrm{g}$ hr light of high latensity from fluorescent lamps gupplemented for the remaining 16 hr with light from Incandescent 1amps) the 1.2 strain required at leagt 6 LD far a $100 \%$ flowering response. Additional LD treatnent further increaged sten elongation to a final helght of approxtmately $40 \mathrm{~cm}$. The dwarf strain flowered in response to 4 LD with a compact Inflarescence but the plants showed hardly any gten growth.

Neither straln responded with flower formation to applied GAs under non-inductive conditions, but differences were observed in the stem growth pattern. Application of $100 \mathrm{\mu g} \mathrm{GA}$ to the shoot tips of 1.2 plants resulted in considerable sten elongation, $\mathrm{Gh}_{3}$ being wore effective than Ch. The dwarf strain responded only slightiy to GA application. Following equal GA 3 treatments the final plant helghts of control and treated plants were 5 and $10 \mathrm{~cm}$ in the dwarf, and 6.5 and $43 \mathrm{~cm}$ in the 1.2 strain, respectively.

Because of the unregponglveness of plants of the dwarf strain to applied CA, 1t became of 1nterest to see if this strain is capable of producing GAs. To examine this, plants of both strains were exposed to $0,1,6$, or $12 \mathrm{LD}$, and the $G A$ content of each group was determined by extraction. As thessured in the $d^{-5}$ corn bioassay both strains had the same $\mathrm{G}$ content. It appears therefore that dwarfism in sizene is not caused by absence of GAs, but to the inabilfty of this genotype to utilize GA.

The relationshlp between atem growth and flower formation was further studied in strain 1.2 by treatment with the growth retardant AMO-1618. Plants were treated for 0,2 , or 4 weeks prior to exposure to Inductive cycles. The plants treated for 4 weeks remained intelally In the rosette stage in LD while the control grotp began to elongate. Bventually the treated plants showed sore stem growth and all groups 
flowered profusely. Thus, although AMO-1618 retarded sten growth, it had no effect on floral induction as was established previously with a different Sitene strain (Cleland and Zeevaart, 1970).

\section{References}

Cleland, C. F., and J. A. D. Zeevasrt, Plant Phyglol. 46, 392 (1970)

We1lenslek, S. J., Proc. Kon. Ned. Akad. Wetensch. Ser. C $75: 179$ (1972)

Hellensiek, S. J., Neth. J. Agrtc. Sct. 21: 245 (1973)

4. The Role of Gibberellin A20 and tts Metabolfte日 in Stem Growth and Flower Formation in Bryophyllim daigremontionum

C. Cetas, J. A. D. Zeeveart

Induction of flower formation in the long-short-day plant Bryophyllum daigramontianion by the trangfer from long days (LD) to short days (SD) 18 accompanted by an tncrease in sten elongation as compared to plants under SD, or In plants grown continuously under LD conditions. Differences in growth rate are correlated with the levels of extractable $\mathrm{GA}_{20}$ (Zeevaart, 1973). However, whtle $100 \mathrm{Hg}$ of exogenously applied $\mathrm{CA}_{20}$ were required to cause flower formation and stem Browth under $\mathrm{SD}$, only 5 LB of $\mathrm{GA}_{3}$ were needed to Induce a comparable response (Gaskin eㅡ al., 1973). The possfbility was therefore considered that $\mathrm{GA}_{20}$ Itgelf has 1ittle or no biological activity In Bryophylizon, but must be converted to a nore active GA. This was investigated by spplication of $2,3-\left[{ }^{3} \mathrm{H}\right]-\mathrm{GA}_{20}$ and studying its metabolism. In order of decreasing ylelds $\mathrm{CA}_{29}, 3-e p i-\mathrm{GA}_{1}$, and $\mathrm{C} / \mathrm{D}$-ring-rearranged (AA $_{20}$ were Identified as the metabolites (Durley et al., 1975). All three compounds have now been tested by injection into the leaves of Bryophylzum plants grown under SD. As shown in Table 1, none of the compounds had any effect on sten growth or flower formation at the levels teated. It is concluded therefore that $\mathrm{GA}_{20}$ per ene, and not its metabolites, Is responglble for stem growth and flower formation in Bryophytion. 
Table 1. The effect of various dosages of four different gibberellins on stem growth and flower formation when injected into mature leaves of Bryophyllum daigremontianum plants grown under short-day conditions. Five plants per treatment.

\begin{tabular}{|c|c|c|}
\hline $\begin{array}{l}\text { GA applied } \\
\text { per plant ( } \mu \mathrm{g})\end{array}$ & $\begin{array}{l}\text { Stem growth } \\
\text { af ter } 84 \text { days (cm) }\end{array}$ & Flowering response ${ }^{a}$ \\
\hline $\begin{array}{l}\text { Control } \\
\mathrm{CA}_{3}\end{array}$ & $\begin{array}{l}14.6 \\
56.4 \\
73.2\end{array}$ & $\begin{array}{l}\mathbf{V} \\
\mathbf{F} \\
\mathbf{F}\end{array}$ \\
\hline $\begin{array}{r}\text { GA }_{29} \quad \begin{array}{r}10 \\
\end{array} \\
\\
100\end{array}$ & $\begin{array}{l}15.0 \\
14.9 \\
15.4\end{array}$ & $\begin{array}{l}v \\
v \\
v\end{array}$ \\
\hline 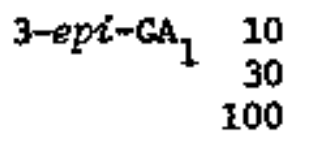 & $\begin{array}{l}13.1 \\
12.9 \\
13.0\end{array}$ & $\begin{array}{l}\mathbf{y} \\
\mathbf{v} \\
\mathbf{v}\end{array}$ \\
\hline 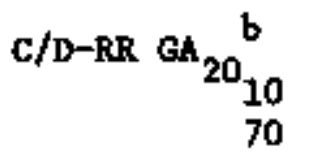 & $\begin{array}{l}13.0 \\
12.6\end{array}$ & $\begin{array}{l}v \\
v\end{array}$ \\
\hline
\end{tabular}

\section{References}

Gask1n, P., J. Mack11lan and J, A. D. Zeevaart, Planta (Ber1.) 111:347 (1973)

Durley, R. C., R. P. Pharis and J. A. D. Zeevaart, Planta (Ber1.) 126:139 (1975)

Zeevaart, J. A. B., Planta (Berl.) 114:285 (1973)

5. S1ter of Absc1otc Actd Syathesig and Metabolism in Ricinus commonis

C. Catag, J. A. D. Zeevaart

The content of abscisic actd (ABA) of young leaves and buds is usually qutte high as compared to that of mature lesver (Plant Research '74, p. 53). It 18 not clear, however, whether this is due to a high

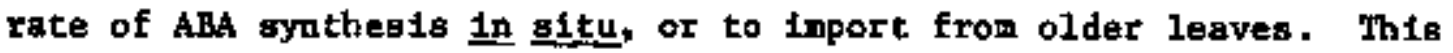
question has been investigated in Riatnus oomronis, because phloem exudate can be eagfly collected in thls plant (Hoad, I973), thus enabling 
one to deternine transport in the phloem of ABA and its metabolites, phaseic actd (PA) and dihydrophaselc acid (DPA).

The acidic fraction prepared from phloen exudate of Riainus was purifled by thin-layer chronatography, and ABA, PA, and DPA were measured quantitatively by gas chromatography with electron capture detector (Zeevart and Milborrow, 1976). Following water stress the concentration of all three compounds in the phloem increaged ovex that in turgtd control plants (Table 1). The largest Increase in the mature leaves was in the ABA content, with amaller rises tn the levelg of PA and DPA. Most striking was the very high DPA content of the ohoot t1pe, even whem the plantg were never under water atresa,

Table 1. The effect of water stress on the contents of absclsic, phaselc, and dihydrophaselc actds in phloen exudate, ahoot tipa, and mature leaver of Rioinus oommonis. Haterial harvested $24 \mathrm{hr}$ after end of atress period.

\begin{tabular}{|c|c|c|c|c|c|c|}
\hline \multirow{3}{*}{ Conpound } & \multicolumn{2}{|c|}{ Phloen exudate } & \multicolumn{2}{|c|}{ Leaves } & \multicolumn{2}{|c|}{ Shoot t1ps } \\
\hline & Turgid & Stressed & Turgld & Stressed & Turgld & Stressed \\
\hline & \multicolumn{2}{|c|}{$\mu_{g} / \mathrm{ml}$} & \multicolumn{4}{|c|}{$\mu g / g$ fresh wt } \\
\hline $\begin{array}{l}\text { ABA } \\
\text { PA } \\
\text { DPA }\end{array}$ & $\begin{array}{l}0.2 \\
0.3 \\
0.4\end{array}$ & $\begin{array}{l}2.3 \\
0.8 \\
3.6\end{array}$ & $\begin{array}{l}0.3 \\
0.2 \\
1.2\end{array}$ & $\begin{array}{l}2.7 \\
0.7 \\
2.8\end{array}$ & $\begin{array}{r}0.1 \\
0.5 \\
18.7\end{array}$ & $\begin{array}{r}0.4 \\
0.8 \\
34.8\end{array}$ \\
\hline
\end{tabular}

When nature or young leaves were detached from the plants and wilted, the level of ABA increased in leaves of both ages, thus demonstrating that young leaves are capable of producing ABA.

It appears from these resulte that ABA Is predominantly produced in the nature leaves, and that ABA Itself as well as ito netabolites are translocated in the phloem to the shoot tips (sinks) where DPA accumulates as the end product of the metabolic pathway. Thus, ABA metabollom can take place both in young and mature lesves, while aynthesis would take place 
mafnly in mature leaves since these leaves show symptoms of water stress firgt. To what extent ABA aynthesis also occuxs in young leaves In gitu remaing to be determined.

\section{Referenceg}

Hoad, G. V., Planta 113:367 (1973)

Zeeveart, J. A. D, and B. V. M1lborrow, Phytochentatry 15:493 (1976) 
STUDIES ON HORMONE ACTION

The action of plant hormonea has been studied fur ther by invedtigating the interaction of cytokining with cellular componenta and by charactertzing blochemical reeponges to hormones. Studies on the site of action of cytokinfns were conducted with tobacco cells cultured fn 1iquid mediuth. These cells are absolutely dependent on added cytokinin for continued praliferation. Experiments on cytokinin binding were also performed with moss protonemata which respond to added cytokinin by Intiation of gametophyte development. It 18 hoped that such experiments will eventually lead to the elucidation of the site of action of plant hormones.

Work on the action of ethylene in senescing flower tissue was also pursted further. The ultingte alm of these experimente ts to find out how ethylene Induces Itg own synthests during the aging process. According to our working hypothests, ethylene causes a 10 s of cellular compartmentation which leads to ethylene generation through intermixing of components of the ethylene generating gystem and eventually to ce11 death. In accordance with this hypothesis, we have further Investigated the pathway of ethylene blogenes1s and have Invegtigated the effect of ethylene on membrane composition. We hope to identify the procesa(es) affected by ethylene that lead to membrane aging and we hope to be able to localize and characterize the components of the ethylene generating system. The action of gibberellic acid on hydrolase synthesis in barley aleurone layerg was also etudied whth the program of hormonemedlated blochemical responseg.

\section{Regulation of Senescence by Ethylene in Flower Tissue}

(a) Relationship betwen Ethytene Evotution and Aging in Morning Glomy Flawer Tiseue

H. Kende, A. D. Hanson

R1b segments exclsed fron the corotla of morning Blory (Ipomoea trioolor Cav,) flowers were used to study the relationship between senescencmp and ethylene production. Such segments, 1solated one or two days (day -1 or day -2) before flower opening (day 0 ) passed through the same developmental 
phases as did the corresponding tissues of the intact organ. When excised on day -1 and lncubated overnight, the rib segments turned from purple to blue and changed from a slightly curled to a flat configuration. On day 0 , these segments rolled up during the afternoon and turned purple again; the rolling up coincided with an increased rate of ethylene production. Premature rolling up and associated ethylene evolution were Induced by ethylene or propylene treatment. When segments were excised on day -2 and Incubated overnight, there were no changes in color or shape; during day -1 , no spontaneous rolling up and little ethylene evolution occurred. Application of ethylene or propylene to these immature segments ellelted rolling up but did not stimulate endogenous ethylene production.

overnight creatment of segments cut on day -1 with benzyladenine $\left(10^{-6} \mathrm{M}\right)$ markediy retarded spontaneous rolling up and ethylene evolution, although the response to applied ethylene was only slightly slowed. Overnight treatment of segtnents cut on day -1 with the ethoxy analog of rhizobitoxine $\left(10^{-5}\right.$ to $10^{-4} \mathrm{M}$ ) resulted in almost complete ( $>99 \%$ ) inhtbition of both spontaneous and propylene-1nduced ethylene evolution. Although spontaneous rolling up was delayed, it was not abolished, and ethylene-induced rolling up was almost unaf fected.

These data indicate that an ethylene-generating system develops as an integral part of the agling process fn flower tissue. Ethytene hastens aging of the flower, but may not play an obligatory role 1n flower senescence.

(b) Ethylene Biosynthesis and Methionine Metaboliam in Senescent Fiower Tisaue of Homing Giom

A. D. Hanson, H. Kende

As in a number of ripening fruits, ethylene produced by senescent. morning glory flower tissue has been shown to be derived principally fron carbon atoms 3 and 4 of methtonine (Plant Research 74, p. 59). The metabolism of tracer quantities of ${ }^{14} \mathrm{C}-,{ }^{3} \mathrm{H}$ - and ${ }^{35} \mathrm{~s}$-methlonine was investigated at various stages in the developant of the flower, in order to correlate rolling up, incresse fn membrane permeabflity and the onget of ethylene evolution with changes in methiontne metabolism (Hanson and Kende, 1976). 
In immature flower rib segments, cut from buds on day -2 and incubated overnight on tracer ${ }^{14} \mathrm{C}$-methionfne, the major ethanol-soluble ${ }^{14} \mathrm{C}$-metabolite present throughout day -1 was a strongly cationic product identified as S-methylmethionine (SMM). In segments prepared on day $\rightarrow 1$ and incubated overnight on ${ }^{14} \mathrm{C}$-methionine, SMM was the najor soluhle tofabolite present in the morning of day 0 before rolling up and ethylene production had begun; as these segments senesced during day $0,{ }^{14} \mathrm{C}$ was progressive1y lost from SMM and appeared in free methionine. Imnature segments contained about 4 nroles of free methionine and about 16 nnoles of SMM per 30 segments. As the segments senesced the methionine content increased about ten-fold while the SMM content cemalned unchanged. During this time about 0.8 nmole of ethylene was released per 30 segments.

The paradox of a decline in ${ }^{14} \mathrm{C}$-label in StM with concomitant production of ${ }^{14} \mathrm{C}$-methiontne, at a tipe when the chemical concentration of SMM was constant, was resolved with tracer experiments using L-methionine- $\mathrm{U}^{14} \mathrm{C}$, L-methionine-methyl- ${ }^{3} \mathrm{H}$ and L-homocysteine thiolactone- ${ }^{35} \mathrm{~S}$. In both senescent and imnature tissue, sum was capable of acting as a methyl donor; only as senescence began, however, was the methyl grotup transferred to homocysteine, to give two molecules of methionine. Of the two product nethionine molecules, one was re-methylated to SWM, the other contributed to the rise in free methionine level. These reactions are surmartzed in Fig. 1.

Because SMN was a prominent metabolite of methionine in both lumature and senescing rib segments, a possible role far Shas a closer precursor of etliylene than methionine was investigated. Following overnight incubation of segments on $10 \mathrm{HM} L-n e t h i o n i n e-\mathrm{U}^{14} \mathrm{C}$, the specific activity of the ${ }^{14} \mathrm{C}$-ethylene evolved was compared with that of $\mathrm{C} 3+\mathrm{C} 4$ of free wethtonine and SMA. The spectfic activity of $\mathrm{C3}+\mathrm{C4}$ of wethionine and SWM extracted from the tissue was deternined using a microscale adaption of the FAt-mediated photochemical degradation of methtonine described by Yang et a․ (1967). As SMM is not an active substrate for this reaction It was first converted to methionine by conc. HCP trestnent (Lavine et al., 1954). Figure 2 shows that the specific activity of the ethylene evolved during senescence closely paralleled the spectfic activity of $\mathrm{C3}+\mathrm{C}_{4}$ of free methionine, conftrming that free wethtonine is the main precursor of ethylene in this tissue. Because the specific activity of skM was about 


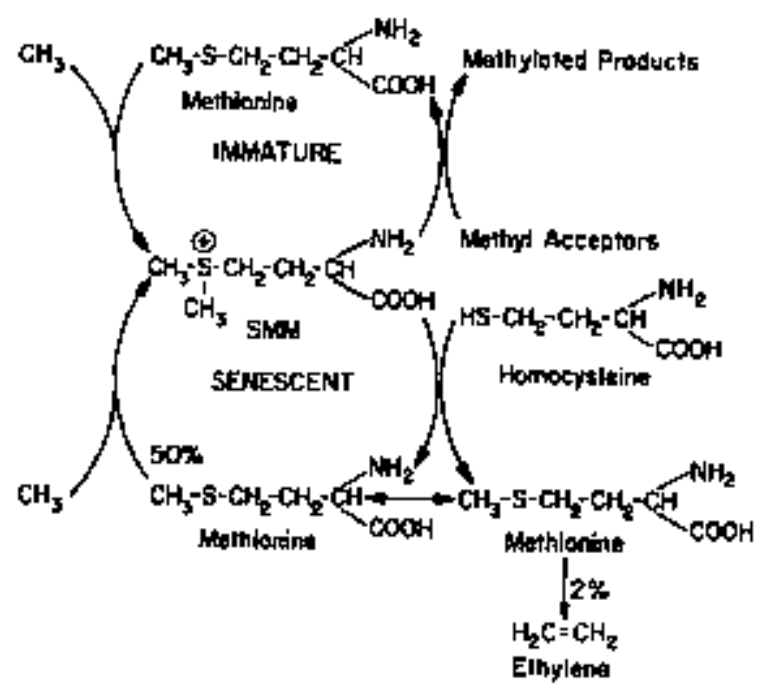

Fig. 1. A scheme for methionine metabolism in relation to ethylene biosynthesis in immature and senescent flower tisswe of morning glory.

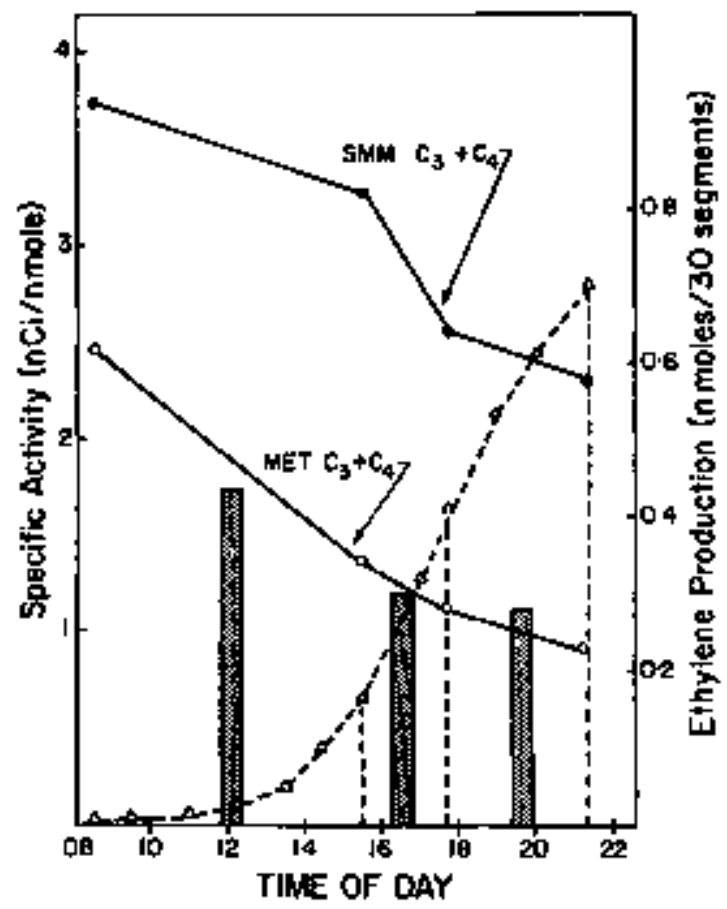

Fig. 2. Specific activities of ${ }^{14} \mathrm{C}_{2} \mathrm{H}_{4}$ and $\mathrm{C3}+\mathrm{C}_{4}$ of me thionine and SMM during senescence. Ethylene was collected during 3 consecutive periods; and at the end of each period a sample of segments was extracted. $\Delta--\Delta$ : tlme course of ethylene ptoduction; the 3 collection periods are Indicated with vertlcal broken lines and the speciflc activities of ethylene collected in each period are shown as bars; $0-0$ : specific activity of $\mathrm{C} 3+\mathrm{C} 4$ of methionine; $--a$ : speciflc activity of $\mathrm{C} 3+\mathrm{C} 4$ of SMM. 
twice that of methdopdne and ethylene, it is very improbable that StM is a closer precursor of ethylene than methionine itself. That the specific activity of $\mathrm{C3}+\mathrm{C4}$ of StP is double that of methionine is consistent with the operation of the pathways in Fig. 1 .

In sumary, the SWM concentration in juvenile morning glory flower tissue is several times greater than that of free methionine. As senescence begins, SMM transfers methyl groups to homocysteine giving rise to a ten-fald increase in the free methionine level; some fraction of this free methionine is then avallable for conversion to ethylene. Two lines of evidence suggest that the synthegis of methionine via this route may 1intt the rate of ethylene production. Firat, although exogenous methionine was unable to influence ethylene production and senescence, homocystaine thlolactone (supplied overaight at $3 \times 10^{-4} \mathrm{M}$ ) consistently provoked prenature rolling up and ethylene evolution. Tracer experiments demonstrated that supply of homocysteine thinlactone stimulated methionine synthesis from SMM in both senescent and immature tissue. Second, ethylene applications which advance the onset of rolling up and breakdown in cellutar compartmentation (Hanson and Kende, 2975) also stivulate ethylene production and the synthesis of methionine from SM. It Is tempting to speculate that ethylene blosynthests during aging 18 regulated by the avaflability of homocysteine to a compartment in which methionine 1s first produced from StM and then is consumed in ethylene production.

\section{References}

Hanson, A. D, and H. Kende, Plant Phystol. 55:663 (1975)

Hanson, A. D. and H. Kende, Plant Phys1ol. 57:528 (1976)

Lavine, T. F., N. F. Floyd, and M. S. Cammarot1, J. Blo1. Chem. 207:107 (1954)

Yang, S. F., H. S. Ku, and H. K. Pratt, J. Biol. Cherk. 242:5274 (1967)

(c) Biobytheeis of Stress-Induced Ethylene in Imatwe Moming Gtory Flower Tissue

A. D. Hansou, H. Kende

Although carbon atoms 3 and 4 of methiontne are known. to give rise to the ethylene evolved duxing the semescence of several frutts (Yang, 1974), the involvement of the methionine pathway In the synthesis of stress-induced 
ethylene 1s less well documented, and available data suggest that another pathway or pathways could be Involved. Abeles and Abeles (1972) were able to account for about one-half of the ${ }^{14} \mathrm{c}$-ethylene produced by chenscally stressed leaves in terms of a methionine pathway. Fruits of the non-ripening IIn tonato mutant, however, produce almost no ethylene spontaneausly but evolve the same amount of ethylene in response to cutting injury as do notmal frutes (Herner and Sink, 1973). Because the ethylene produced by senescing mornting glory flower tissue is derived from methiontne, the same tissue was used prior to senescence to assess the contribution of the methionine pathway to stress-induced ethylene synthesis (Hanson and Kende, 1976).

RIb segments cut from buds on day -2 evolved a stall quantity of ethylene on day -1 , principally durling the morning. When such segments were stressed mechanfcally (lay cutting into sulali pleces, by crushing or by multiple performations) early in the afternoon, ethylene production increased more than ten-fold within 1 hr and subsided to a low rate after about $3 \mathrm{hr}$ (Fig, 3).

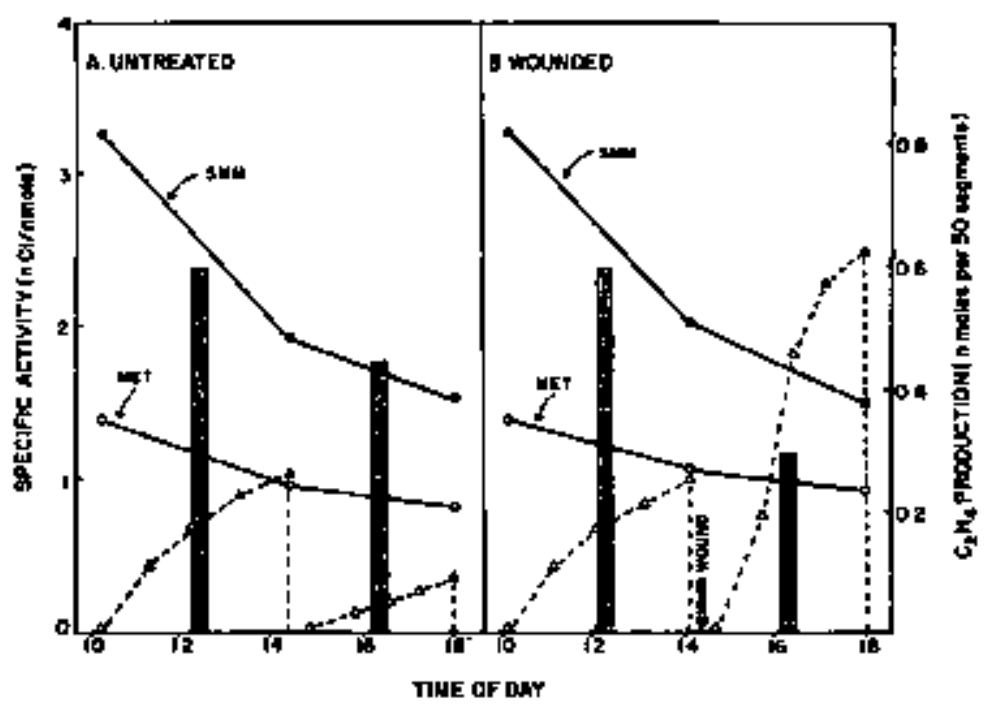

Fig. 3. Effect of wounding on the specific activities of ethylene and $\mathrm{C} 3+\mathrm{C} 4$ of methionine and SMM. Ethylene was collected during two perfods from untreated segments (A) and from segments wounded (arrow) by multiple perforations (B). The spectfic activities of the ethylene evolved during the two collection periods are shown as bars. $\Delta----\Delta$ : time course of ethylene evolution; o- 0 : specific activity of $\mathrm{C3}+\mathrm{C4}$ of methionine; --: specific activity of $\mathrm{C} 3+\mathrm{C} 4$ of SMM. 
Evolution of ethylene by both untreated and otressed segments was inhtbited more than $95 \%$ by overnight pretreatment with the ethoxy analog of rhizobitoxine $\left(3 \times 10^{-5} \mathrm{M}\right)$; thizobitoxine and 1ts analogs are regarded as spectflc 1uhibitors of the utilization of wethionine in the pathway of ethylene synthesis.

After overnight exposure of segments to tracer (9 $\mu \mathrm{M})$ L-methionine$\mathrm{U}-{ }^{14} \mathrm{C}$, the spectfic activity of the ethylene evolved by untreated and stressed segments was determined and compared with the spectfic activities of $\mathrm{C} 3+\mathrm{C} 4$ of methionine and SMM extracted fron the tissues (B1g. 1). The specific activity of the ethylene produced by untreated segments was close to that of SMM, while In stressed tissue the specific activity of the ethylene evolved was somewhat lower, although still above that of methionine.

The rhizobitoxine analog and ${ }^{14} \mathrm{c}$ data are consistent with the synthesis of the bulk of the stress-induced ethylene from methlonine, possible from a small pool of relatively high specific radiaactivity which is not in rapid equilibriun with other pools of free methionine in the tissue.

\section{ReFerenceg}

Abeles, A. L. and F. B. Aheles, PIant Fhystot. S0:496 (1972)

Hauson, A. D. and H. Kende, plant Physiol. 57:538 (1976)

Herner, R. C. and K. C. S1nk, plant Phystol. 52:38 (1973)

Yang, S. F., Rec. Adv. Phytochetw. 7:131 (1974)

(d) Senesonce and Phosphotipid Content of Nembranes of Moming Glory Plower Tisaus

E. Beutelmann, H. Kende

Barlier results on aging in morning glory flower tissue indicate that the senescence process will proceed even if over $99 \%$ of the ethylene evolution has been inhlbited. From such data, we concluded that ethylene production may be a fairly late event in sging, and that prior blochemical processes mut proceed 1t. Since avallable evidence supports the bypothesis that ethylene syothesis is a consequence of loss of cellular compartmentation, we decided to investigate membrane composition of porning glory flower tissue prior to and during senescence. Inttlally, the level of phospholipid in total membrane preparation has been Investigated, but an extension of these experiments to other lipld components and to specific membrane fractions is planned. 
Before the onset of genescence, there is a continuous, slow decline in the content of phospholfpid. At the time when rib segments roll up and when they start to produce ethylene, the rate of phospholipid loss 1s accelerated by about 10-fold, resulting in a 50\% loss within $8 \mathrm{hr}$ (Fig. 4).

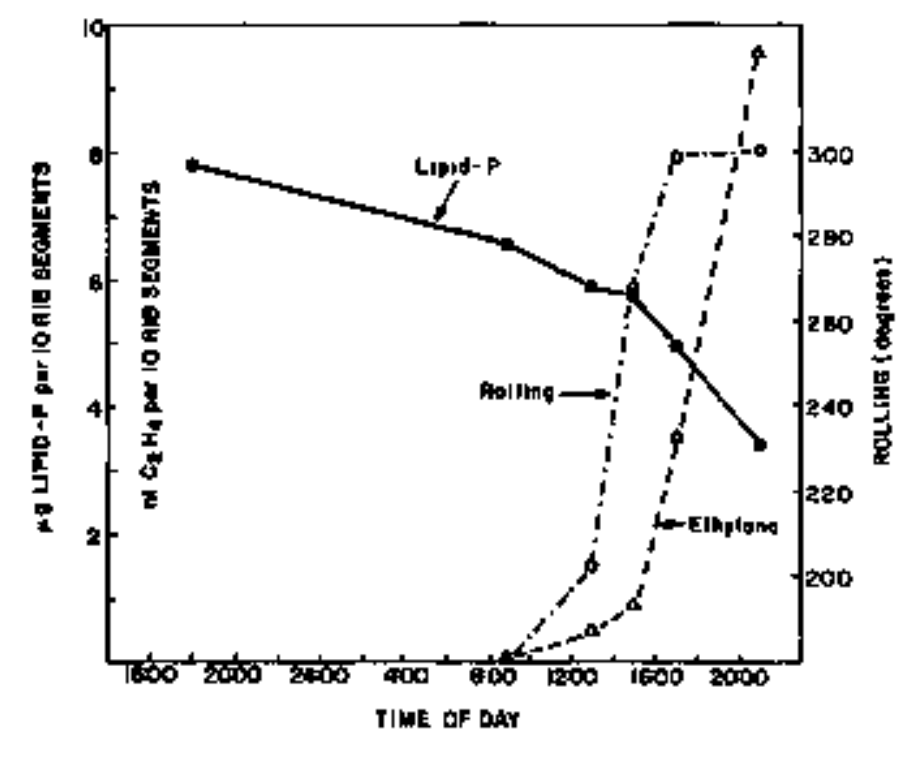

Fig. 4. Loss of phospholiplds, ethylene production and rolling up of rib segments of morning glory flower tissue.

Exposure of mature tissue to ethylene on the day of flower opening accelerates rolling up, ethylene production and phosphollpid degradacion. In Juvenile tissue, ethylene treattment causes rolling up and enhancement of phospholipid loss. The ratio of the major phospholipids (phosphatidylcholine, phosphatidylethanolamine and phosphatidylinositol) and the associated fatty actds remains constant during the period of degradation.

These results are consfstent with the hypothesis that ethylene production is preceded by membrane changes which are accelerated once ethylene synthesis commences. 
(e) Sensacence of Ftower Tissus of Tradescantia hirsuticautis

J. Suttle, H, Kende

Flowers of hradesaantia are ephemorous; they open early in the marning and fade on the same day. In pursuing our hypothesis that aging and ethylene production are due to loss of cellular compartmentation, we have studied senescence of Tradescantia flower petsls, as this can be monitored by following the loss of anthocyanin from the cell. Since this plgment is originally localized in the vacuole, its efflux from the cell significies a gross loss of cellular integrity. Flower petals were excised and floated on water In a closed vessel stoppered with a serum vial cap and equipped with a side arm. Anthocyanin loss in the bathing medium was monitored spectrophotanetrically by transferring the bathing medium into the side arm which could be inserted into a color1meter. Simultaneously, ethylene generation was monitored by withdrawing gas samples fron each flask. When flower petals were treated with ethylene, prenature senescence and anthocyanin efflux were observed (F1g. 5).

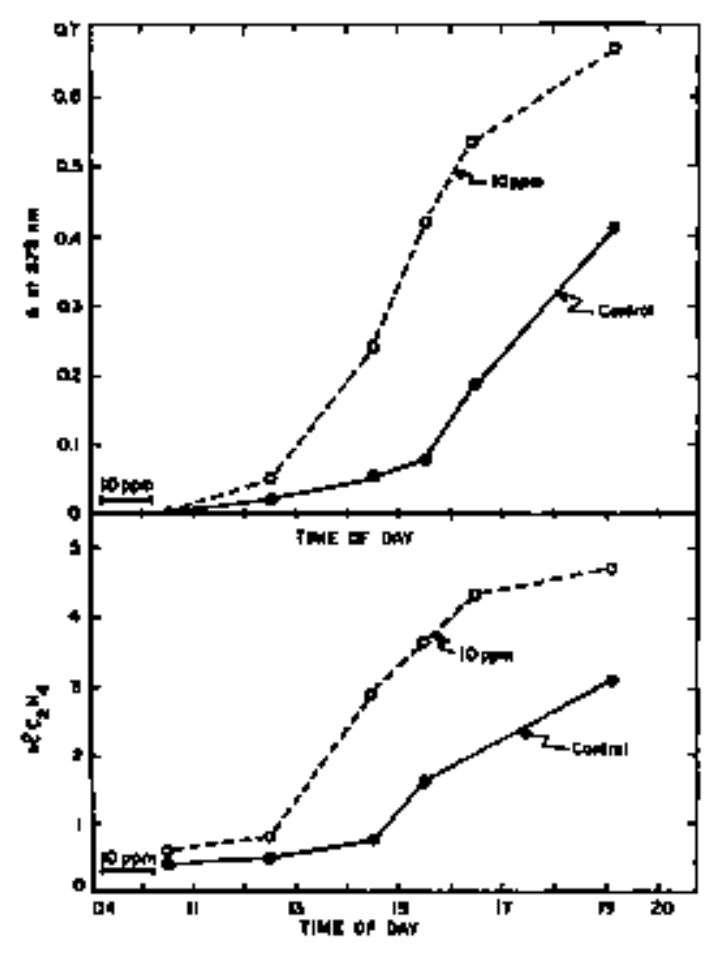

F1g. 5. Effect of a pretreatment with $10 \mathrm{ppm}$ ethylene for $1 \mathrm{hr}$ on ethylene evolution and anthocyanin efflux in isolated Tradescantia petals. Seventeen petals per $5 \mathrm{ml} 5 \mathrm{mM} \mathrm{KCl}$. 
In naturally aging petals, celease of anthocyanin was accompanfed by rloing ethylene production. Th1s was taken as further evidence that ethylene symthesis is intinately connected to loss of cellular compartmentation. Carbon dloxide, an antagonist of ethylene action in many systems, Inhibited aging of the flower tissue. Similarly, an analogue of rhizobitoxine almost coppletely inhibited fading of the petals and ethylene evolution. The latter result points to the methionine pathway as the origin of ethylene. This was further verified by showing that the specific radioactivity of ethylene very closely matched the specific radioactivity of the carbon atoms 3 and 4 of methlonine extracted from the tissue. Ilke in Ipomoed, applied ${ }^{14}$ C-methionine was converted to S-methylmethionine which was reconverted to methionine during aging. This is further confirmation of the fact that the S-methylmethionine $\rightarrow$ nethlonine pathway must be operating when ethylene is generated.

\section{Hormone Binding In Plant:}

(a) Cytokinin Binding to a Nembronous Fration from Cultured Tobacoo Cells

M. R. Susgman, R. deZacks, H. Kende

Using a liquid suspension culture of cytokinin-dependent tobacco cells, we have cont1nued oux Inveatigations of an tn vitro, particulate, 'high'affinity ${ }^{3}$ H-benzyladentne $\left({ }^{3} \mathrm{H}-\mathrm{BA}\right)$ binding alte (see Plant Research '74, p. 60). In order to more rigorously determine whether binding activity correlates with blological activity, we have synthesized and tested a sexies of benzyladenine analogues differing by a single halogen substitution in the benzene ring. Iceally, the best such analogues for this study would be those where the nost subtle chemical change would produce the most dramatlc change in blological activity. It was originally hoped that trans- and cis-zeatin would be sultable for this purpose but, as shown In Figure 1, trans-2estin 1 s significantly lesa active than BA, and the wo stereolsomers are only maginally different in their blological activity. The ontho-, meta-, and para- derivatives of fluoro-, chloro-, or bromabenzyladenfne analogues do, however, bhow grosg differences in blologlcal activity (Fig. 1). It is evident that (1) logs of activity correlates wth Increasing bulkiness of the halogen rather than its electronegativicy (e.8., compare BA, pCl-BA and $p$ F-BA) and (i1) substitution in the orthoposition least affects biological activity, 


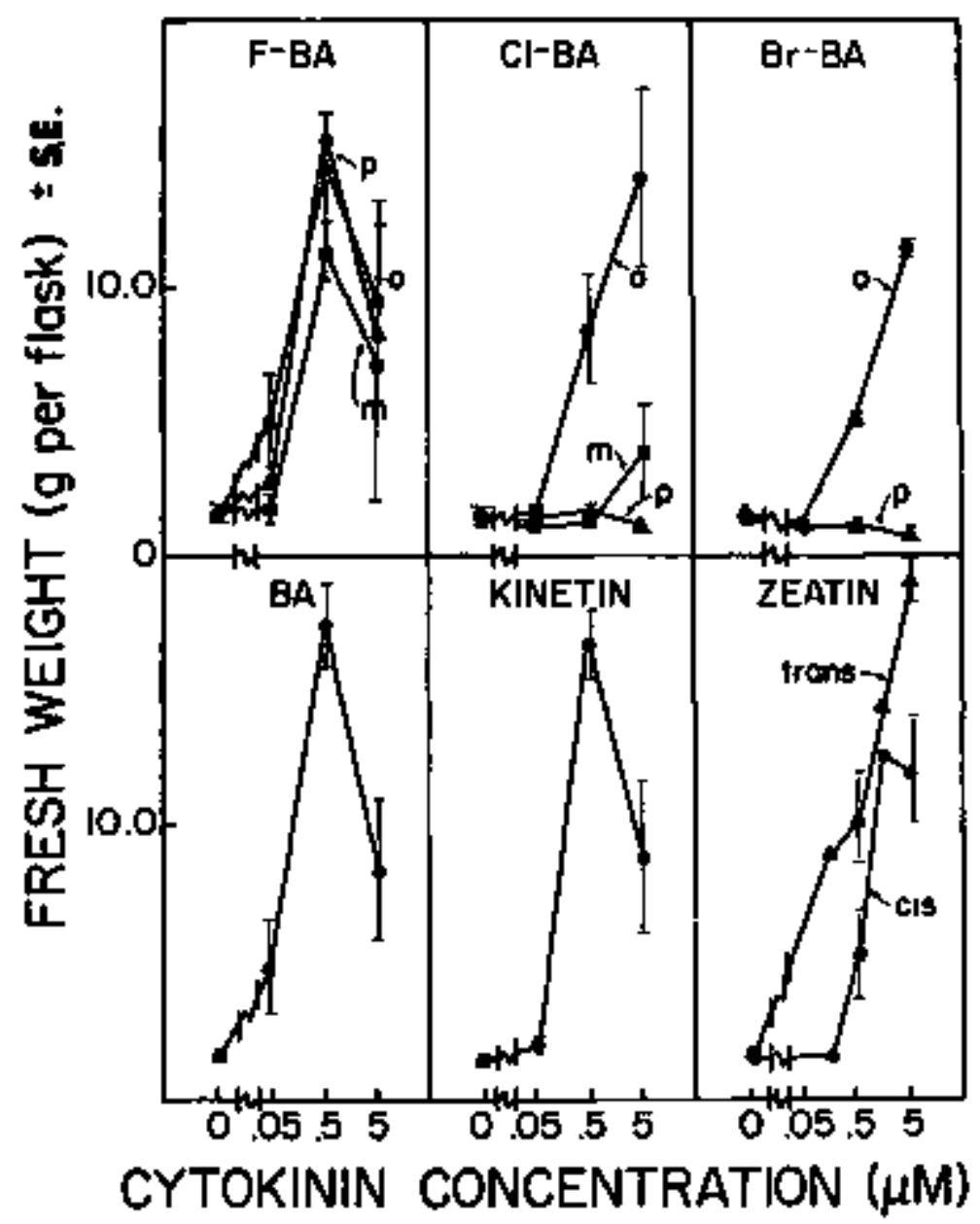

FIg. 6. Tobacco callus bloassay of optho-, meta- and para- fluoro-, chloro-, and bromo-benzyladenine derivatives and other known cytokinins. Fresh weight was measured after 2 weeks growth in liquid culture. Depicted is the average with standard error of the results of at least 5 experiments.

These data are 1n agreement with results of okumura 로 aㅣ. (1959) using the chloro-derivatives of BA In the radish leaf assay. Most 1mportant, however, the differences in biological activity correlate well with the ability of the analogues to compete with ${ }^{3} \mathrm{H}-\mathrm{BA}$ in the binding assay (Table 1). This is as expected if the observed binding were physiologically significant. 
Table 1. Binding assay (at $0-4^{\circ} \mathrm{C}$ ) of cytokinin analogues using an $80,000 \times g$ (30 minutes) particulate nembrane fraction of the 11quid tobacco suspension cultures. The results of a single experiment are shown as the avexage with standard error of triplicate samples. Absolute values vary between experiments, but the general relative order of activity does not.

Corpound Tested*

Benzyladenine

(BA)

O-FIUOTO-BA

m-Fluoro-BA

p-Fluora-BA

o-Ch1oro-BA

m-Chloro-BA

$p$-Chloro-BA

o-Bromo-BA

P-Bromo-BA

Kinetin

ois-zeatin trana-zeatin
Competible Bound CFM per Pellet \pm S.E.

$$
\begin{array}{r}
318 \pm 27 \\
279 \pm 20 \\
249 \pm 26 \\
271 \pm 27 \\
227 \pm 25 \\
118 \pm 34 \\
72 \pm 28 \\
200 \pm 32 \\
34 \pm 24 \\
284 \pm 27 \\
134 \pm 16 \\
166 \pm 16
\end{array}
$$

"All tubes contatn $5 \times 10^{-9} \mathrm{M}{ }^{3} \mathrm{H}-\mathrm{BA}$. The non-radloactive compounds tested above were added at $5 \times 10^{-7} \mathrm{~K}$.

When ${ }^{3} \mathrm{H}-\mathrm{BA}$ binding assays are done on the vartous membrane fractions separsted by equilibrium sucrose density gradient centrifugation (15-45\% w/w sucrose), there is conalderable high-affinlty saturable binding in all fractions. However, of crucial importance is our finding that heatlabile high-affintty saturable binding is exclusively linited to a fraction equilibrating at $30-40 \%(w / w)$ sucrose. Unfortunate1y, this region of the gradient contafns many of the najor nembrane and organelle fractions, and it has not yet been posalble to determine specifically which membrane fraction $1 \mathrm{~s}$ Involved in cytokinin binding. The heat lability of cytokinin bjoding activity of this membrane fraction is in direct contrast with the 
low-affinity-gaturable and non-saturable binding which actually increases as much as three-fold after a heat pre-treatment. Thds was the matn reason for concluding that the ${ }^{14} \mathrm{C}-\mathrm{BA}$ binding reported earlier (Plant) Research '72, p. 67) was phystologlcally probably not signiflcant.

\section{Reference}

Okumura, F. S., Y. Kotani, T. Ariga, K. Masumare, and S. Kuraish1, Bull. Chem. Socc. Japan 32:883 (1959)

(b) Binding of Cytokinins to Particulate Bractions from Moss Protonemata

G. Gardner, M. R. Sussman, H. Kende

We reported in Plant Reseacch '74 (p. 6I) preliminary experiments on the binding of ${ }^{3}$ ti-benzyladentse (BA) to a $13,000-80,000 \times g$ particulate fraction of moss extracts. During 1975 our major effort wes directed toward characterization and purffication of the active material with the hope that we might be able to identify the sub-cellular fraction(s) containing binding activity. As we reported, active cytokinins competed for the binding of ${ }^{3} \mathrm{H}-\mathrm{BA}$, whereas the ribosides of the free baseg, which are Inactive in causing bud formation in moss, competec poorly. These studieg with cytokintn analogues were expanded, and additional attempts were ugde to optimize binding. In addition, it was found that ${ }^{3}$ H-zeatin would bind to these fractions, although the extent of binding was not as great as with ${ }^{3} \mathrm{H}-\mathrm{BA}$.

Two approaches were taken to 1solate the active fractions. The firgt utilized sucrose equilibrium denstity gradients. Initial experinents Indlcated that che binding activity night be concentrated in certain gradient fractions; however, later expertments ylelded different gradient profiles. It vas felt that the varfability observed was inherent in the procedureg necessay for cell breakage and extraction of the tough-walled moss protonemata, and no valid conclusions about the localization of the binding activity could be drawn. The second approach was to solubilize the binding activity with the detergent Triton $\mathrm{X}-100$ and attempt to detect competition in the Triton-soluble supernatant using ge1 filtration techniques. When Triton-solubilized materfal was udxed with ${ }^{3} \mathrm{H}-\mathrm{BA}$ and chromatographed on a Bfo-Gel P-6 column, radioactivity was found in the exclusion volume of the colums. The amount of radioactivity in this high molecular weight 
fraction was reduced if the column was eluted in the presence of nonradiosetive BA. While it thus appears as if we had shown specific BA binding in the detergent solubilized material, the possibility exists that the hormone was Interacting with the detergent (see below). Unt1l the question of non-spectfic detergent Interactions is resolved, we will not be able to deterwine whether we have successfully solubilized specific hormone binding activity.

A report of cytokinin binding to ribosomes (Fox and Erion, 1975) made 1 t Imperative to determine whether we were observing the same phenomenonn. The $80,000 \times g$ gupernatant was centrifuged for $2 \mathrm{hr}$ at $95,000 \times g$, and the resultant pellet was used for the binding assay. It was found that the binding activity was much grester in the $13,000-80,000 \mathrm{x} g$ pellet than in the higher speed pallet which putatively contalned ribosones. These two pellets vere analyzed for RWA, and it was clear that the binding was not correlated with the RMA content of the fraction. Thus, the binding activity which we have observed is probably different than the binding of cytokinins to ribosomes reported by others.

It had been polnted out by Cuatrecasas and Hollenberg (1975) that the anfmal hormones 1nsulin snd adrenalin can bind to nonspectfic adsorptive materlals and that this binding can exhibit saturability and even stereospectfictiy. We have found this to be a sertous problem with cytokinins. We had observed that BA binds to glass, and this effect could be quantified with talc powder. We found that ${ }^{3} \mathrm{H}-\mathrm{BA}$ bound to a $1 \mathrm{ng} / \mathrm{ml}$ suspension of talc, and the bound counts were displaced competitively by non-radioactive BA, zeatin, ox 1sopentenyladenine. Zeatin-riboside and Isopentenyladenfne-riboside were less effective competitors. 3y-zeatin also bound to talc in the game manner. The detailed properties of the binding of BA to talc were found to be different than those to the blological fractions, e. mose fractions was much wore susceptlble to heat treatment than binding to talc. Fowever, our mafor concern, which applies as well to all other studies in the area of cytokinin binding, is to digtingutsh between binding that is biologfcally meaningful, and hopefuliy reflects recepter interactions, and binding which Is bimply non-meaningful physical adsorption. 
References

Cuatrecssas, P. and H. D. Ho11enberg, Blochem, B1ophys, Reg, Commun. 62:

31 (1975)

Fox, J, E. and J. L. Erion, Blochen. Blophys. Reg, Commun. 64: 694 (1975)

Takegant, T. and K. Yoshida, Blochem. Blophys. Reg. Colmun. 67: 782 (1975)

(c) In Vivo Binding of ${ }^{3}$-Benayladenine in Moss Protonemata

G. Gardner, H, Kende, R. deZacks

Moss protonemata were 1ncubated for $24 \mathrm{hr}$ on a medium contafning $10^{-8} \underline{M}$ 3H-benzyladentne (BA) plus varying concentrationg of non-radioactive BA. The plants were then welghed, and total radioactivity in the tissue was deterwined. The data, expressed as radioactivity per fresh weight, indicated that over half of the ${ }^{3}$ H-BA uptake can be competed by non-radioactive BA. Competition could be observed after as 11ttle as $4.5 \mathrm{hr}$; one hour was Insufficient. Thin-layer chromatographic analyses indicated that the radloactivity was st111 assaciated wth BA.

Adenine, which does not cause bud formation, did not compete for the uptake. BA-riboside, which also does not cause bud formation, successfully corpeted with ${ }^{3}$ H-BA. The fact that BA-riboside competed in the in vivo

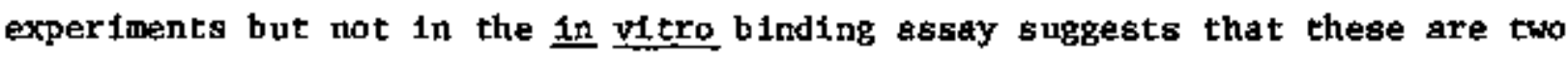
separate phenotnena and that the In vivo expertments way repreaent a cytokinin uptake system. If so, we reasoned that wa night be able to separate these systens by comparing the effect of HA-riboside on uptake at room temperature and at $4^{\circ}$. At the lower temperature, one might expect the tiptake system, If active, to be less important and the (putstive) receptor interaction ¿c 4 more obvious. The experimental results were consigtent with this prediction. BA conpeted well at elther $19^{\circ}$ or $4^{\circ}$, whereas BA-riboside only competed at $19^{\circ}$.

3. Effects of 5-F1worouracll on RNA and a-Amylase Synthests in Barley Aleurone

S. Rodaway

Gibberellic acid Induces the de novo synthesis of a-amylsse and some other hyorolytic enzynes by the barley aleurone 1ayer. We attexpted to determine whether the mRNA coding for $\alpha$ mmylase was also synthestzed de povo In response to GAs or whether it existed in gome form where it was unavaflable 
for translation prior to addition of the hormone. It seemed that the method of cholce for determining the time of the onset of the a-amylase mRNA syathesis would be that employed ear11er by Carlson (1972) which used the base analogue 5-fluorouracil (FU) to produce "faulty" mRNA which, in turn, caused differences In thermal stability of the enzyme synthesized after various pre-incubations wth the drug.

Last year we reported (see Plant Research, '74, Pp. 66-7) that we had been unable to find $\alpha$-anylase populations with different thernal stabititles after lengthy Incubation with Fu and we have now extended those observations. a-Amylase was purified from barley half-seeds (cv. Betzes) to the stage where one molecular weight component (MW 41,400 $\pm 1,000$ ) was visible after electrophoresis on polyacrylanide gels containing 17 SDS. The enzyme, which represented $3 \%$ of the orfginal half-seed proteln had two peaks of activity in a preparative isoelectric focusing system (about $\mathrm{pH} 5.0$ and $\mathrm{pH}$ 6.1), two peaks of activity following chromatography an DEAE-cellulose and $\mathrm{s} 1 \mathrm{x}$ electrophoretic isozymes distingulshed by activity under non-denaturing conditions. The 1sozymes were present in roughly the same ratios before and after puriffeation, and the purified enzyme was essentialiy free of carbohydrate and protease. Lengthy FU treatment of the half-seeds had little or no effect on the net amount of a-anylase synthesized, the recoverability of enzyme at sny stage of the purification, the appearance of isozyme patterns, or the final specific activity of the enzyme. The thermal denaturation process 1 tself was found to be Independent of enzyme concentration at least up to $440 \mathrm{Hg} / \mathrm{mI}$ and not to occur 1 the presence of high levels of calctum. The denatuxation kinetics were the same for $\alpha$-anylase from half-seeds incubated in $10^{-3} \mathrm{M}$ FJ for 3.5 days out of a total imbitition time of 4.5 days with $\mathrm{GA}_{3}$ added for the last $36 \mathrm{hr}$. other experiments Including Fo for the entire 4.5 days of treatuent also produced $\alpha$-anylases with the same stabilities.

$10^{-2} \mathrm{~K}$ FU was found to inhtbit at least $90 \%$ of rRNA and 4-5 s RNA syathesis In aleurone layers while only $10 \mathrm{Z}$ of the anylase activity was affected. $10^{-4} \mathrm{M}$ FU had a lesser effect (about $30 \mathrm{~F}$ inhtbitton). Thus Fu was able to enter the aleurone tissue of the half-seeds and to exert its effect, 1 .e. the inbibition of rRNA synthesis. These results imply either (i) that Fu did not sufficlently alter nRNA nucleotide sequences to cause changes in the a-amylase primary structure which would be evidenced by changes in the enzyme thermal stab1lity or (11) that the a-amylase mRNA pre-extsted in 
the dry hatf-seed or was syathesized during the tibe it took to build up the FU-ribosyl triphoephate poot, the prectursor for incorporation into RWA. New rRNA or 4-5 S RKA was not required for a-amylase synthesta.

\section{Reference}

Car1son, P., Nature 237:39 (1972) 
DEVELOFMENT AND NITROGEN FIXATION IN FILAKENTOUS

BLUE-GREEN ALGAE

Fllamentous blue-green algae (cyanobacterla) form multlcellular patterns by mechantsms termed "fieldg of Inhibitton" and "Inductiong" in developmental blology. Thus, afferentiated cells called heterocysts inhibit nearby vegetative ce1ls from beconing heterocysts (Wolk, 1967) and, in Arabaena oyindmica, Induce adjacent vegetative celis to sporulate (Wolk, 1966). Because these algae have three types of celis (vegetative cells, heterocysts, and spores or akinetes), they permit comparison of alternative differentiation processes withfn an organtem which has a simple structure. Studies of pattern formation in these morphologically simple organismos may serve as models for Investigations of pattern formation in higher organisms, both plants and antmals.

Aeroblc flxation of dinitrogen $\left(\mathrm{N}_{2}\right)$ is known to take place to a gubatantial extent, and perhaps oniy, in the heterocysts, and is dependent on a cooperation between these cells and the vegetacive. The latter supply heterocysts with products of photosynthesis and recesve, in return, products of $\mathrm{N}_{2}$ fixation.

The goals of this research profect are (1) to elucldate the blachemical bases of pattern formation, and (11) to anslyze the mechanisms underlying photosynthetic nitrogen fixation by these algae.

In order to elucidate the Intercellular interactions which control the pattern, we are presently trying to Identify algal products which can control the differentiation of spores ( 1 , below), and we are seeking by use of ${ }^{13} \mathrm{~N}$ to Identify substances which wove from cell to cell (2, below). The latter project is also a meang to Identify certain of the Intercellular interactions underlying photosynthetic nitrogen fixation by heterocysts. Our efforta to determine the princlpal blochemical differences which distinguish the three cell types continue to concentrate on the envelopes of heterocysts and spores (3, below), becatie these envelopes are eariy, major products of differeatlation. Detalled study of the Intraceliular control of differentiation must awalt detailed knowledge of the Intaractions, and of the blochemical differeaces they control.

\section{References}

Wolk, C. F., Am. I. Bot. 53:260 (1966)

Wolk, C. P., PNAS 56:1246 (1967) 
1. A Substance Stimulating the Differentiation of Sporeg in the Blue-Green Alga Cy indrospermom lioheniformie

R. W. Flsher, T. Hirosawa, P. W. Shaffer, C. P. WoIk

Filaments of Cylindrospexmun thoheniforme culcured in phosphate-free medium (sportlation medtum) sporulate adjacent to heterocygts. Centrifugal aupernatant flulds from sporulated cultures stimulste sportlation of freshly froculated algae. Thus, filamenta grown in sporulation medtum show no acceleration of sporulation until the fifth day of culture, wheress the acceleration of sporulation of filanents grown in conditioned eporulation mediun starts essentially tmediately (FIB, 1).

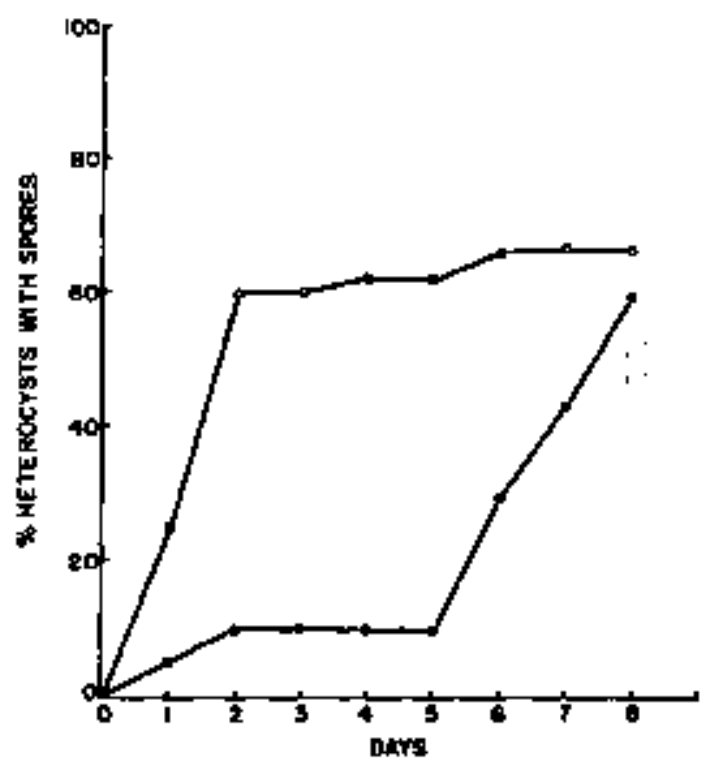

Fig. 1. Time course of sporulation of $C$. Lisheniforme In sporulation medius (o) and in sporulation madium conditioned by prtor growth and sporcilation of the alga (o).

The final percent sporulation is approxinately the gane in the two cultures. Growth and sporulation of $C$. Tichenifonme in sporulation medium therefore modifies that medium in a way that nakes it stimulatory to spore formation upon reinoculation. Conditioning has no signiftcant effect upon growth, or upon the pH of the mediurs. 
Supplementation of conditioned sporulation medium wh all of the constituents of sporulation medium does not affect the sporulation-stitulation which resulta fron conditiontng (Table 1).

Table 1. The effect of supplementing condttioned nedium with components of fresh sporulation medium.

Medium

F Heterocysts with spores

Expts, $A^{\mathrm{a}} \quad \operatorname{Exptg} \cdot \mathbf{B}^{\mathrm{a}}$

Sporulation medim

$6.4 \pm 2.7^{b}$

$5.8 \pm 2.6^{b}$

Conditioned sporulation medium

$66.0 \pm 6.1$

$64.8 \pm 6.6$

Conditioned, supplenented

$68.0 \pm 13.8$

$67.2 \pm 12.8$ sporulation meditm

an experiments A, congtituents of sporulation medium were added to IIquid, conditioned sporulation medium. In experiments B, Ilquid sporulstion nedium was added to Iyophilized, conditioned sporulation medium.

blean value, pius or ninus standard deviation, from five experimenta, each of which was assayed after three days of culture.

Supplewented conditioned sportation wedium contalns all of the components of sporulation gediun in concentrations equal to or greater than their concentration in sporulation medium. The stimulation of sporulation which is effected by conditfoning of sporulation mediun is not, therefore, the result of a depletion of the medium. Rather, the filaments produce a substance which It released into the medium and which stimulates the differentiation of spares 1n newly inoculated filaments. Sporulation of the original inoculum may result from an Increasing concentration of this same substance.

Conditioned sporulation medium is diluted, 1:19, with fresh sporulation nedium sporulation is ot:1ll accelerated 50\%as mich as by undiluted conditioned medium.

Our current efforts are directed toward purtfication and identification of the sporulation-stimulatory substance(s) released Into the medium by sporulating cultures and possibly 1nvolved, within filaments, in 
an induction, by hetezocyats, of the sporulation of adjacent vegetative cells.

2. Products of the Fixation of Nitrogen Gas by F1laments and Heterocysts*

C. P. Wolk, J. Thomas, J. Meeks; S. Aust1n, A. Galonsky (MSU Cyclotron Laboratory)

In order to determine the products of fixation of nitrogen gas by heterocysts, we have with intact filaments developed techniques for Identifying products of nitrogen flxation, using $13 \mathrm{k}-1 \mathrm{ab}$ eled attrogen gas $\left[t^{13} \mathrm{~N}-\mathrm{N}_{2}\right]$. The experiments represent a means of eluctdating certain of the interactions whereby heterocysts and vegetative cells cooperate in the fixation of atmospheric nitrogen, and which way posalbiy be involved also in the intercellular control of pattern formation.

Suspenstons of algal filaments are exposed to $13 \mathrm{w}^{\mathrm{N}} \mathrm{N}_{2}$ for varying periods of time, then combined with four volumes of methanol, and the filaments sedimanted by centrifugation. The $80 \%$ methanolic gupernatant extract ig concentrated under vacuum, spotted on a cellulosic thin layex plate, and aubjected to electrophoresis at different $\mathrm{pH}^{\mathrm{s}} \mathrm{s}$, and sometimea also to chromatography (Thomas et 이., 1975).

As illustrated In Fig. 2, substances coelectrophoresing in borate buffer, $\mathrm{pH}$ 9.2, with (and which have by meang of additional experiments been identifled as) glutamine and glutanate are the princlpal inttial prgante products of flxation of $13 \mathrm{~N}_{2}$, with glutamine labeled much more rapidly than glutamate. Distillation experinents have shown that even after I win of fixation, the amide nitrogen of glutamine is much more extengively labeled than is its a-anino nitrogea (ratio ca. 6:1). Pulse-chase experiments showed clearly that radloactivity from glutamine is transferred to an acceptor wolecule to form ${ }^{13} \mathrm{~N}$-labeled glutamate. Consistent with this observation, azaserine (an Inhtbitor of glutarane anide transferases) pernits the synthesto of glutamine, but cotally blocks the formation of glutamate. That (as expected) ammonia serves as the precursor of glutamine anide nitragen was shown by the kinetics of labeling of these two products during short pertods of labelfing (FIg, 3), and by the observation that methionine sulfoxtmine permitted continued formation of ${ }^{13} \mathrm{NH}_{3}$ while preventing ${ }^{13} \mathrm{~N}$-labeling of glutamine and glutamate.

"Supported in part by National Sclence Foundation. 


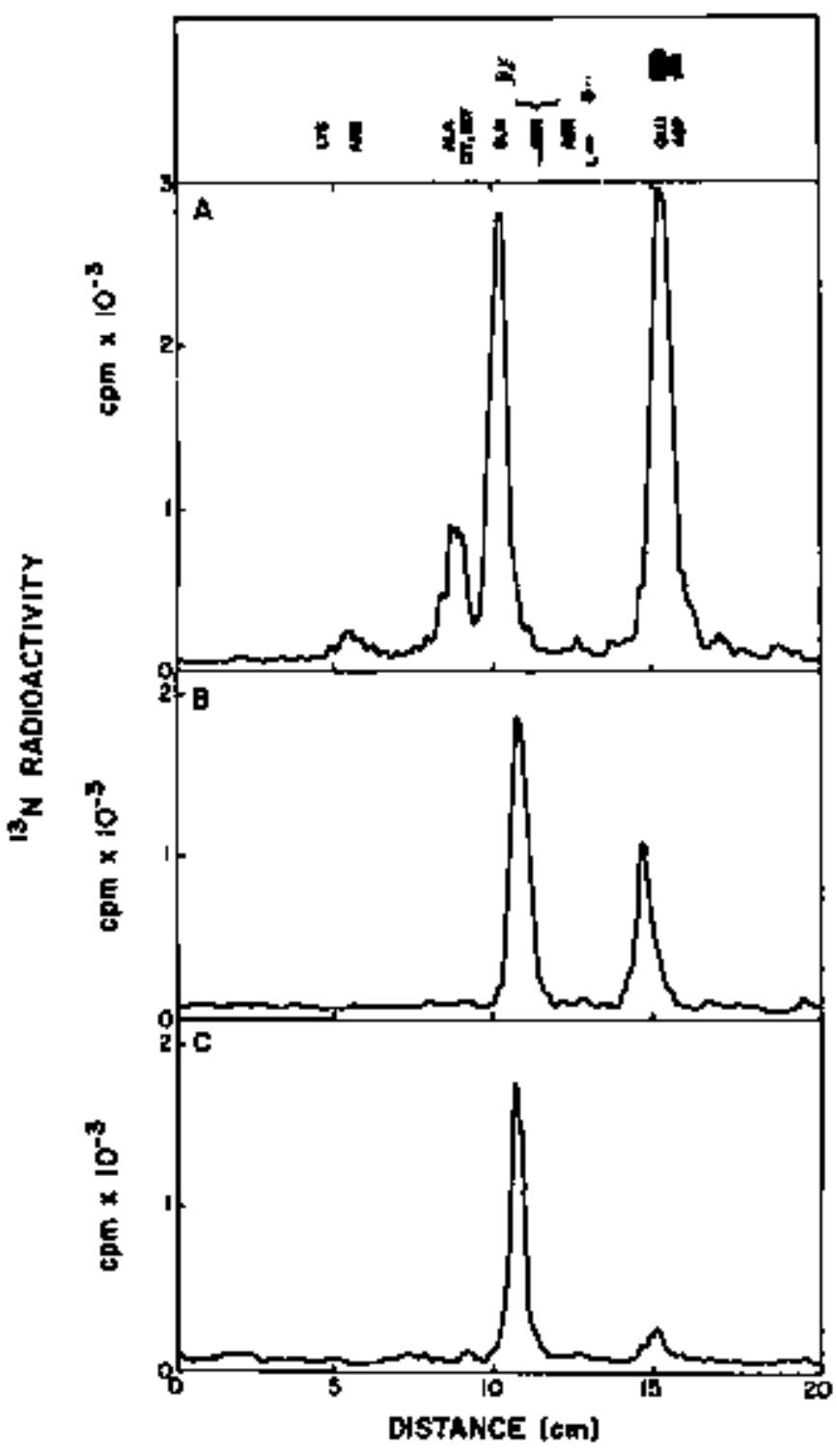

Fig. 2. Scan of radioactivity from ${ }^{13} \mathrm{~N}$ in thin Iayer electrophoretograms of orgenic corpounds extracted from Anabaena cylindrioa with $80 \%$ methanol after (A) $120 \mathrm{~s}$, (B) $60 \mathrm{~B}$, and (C) $20 \mathrm{~s}$ of fixation of $13_{\mathrm{N}-1 \mathrm{abeled} \text { nitrogen }}$ gas. Unlabeled atmino acids, coelectrophoresed as markers, were localized with ninhydrin. $0=$ origin; $L$ - lipids, displaced from the origin by chromatography. The 13N-containding substances in (B) and (C) co-electrophoresed with glutamine and glutamate, as did the two major 13N-containing Bubstances in (A). 


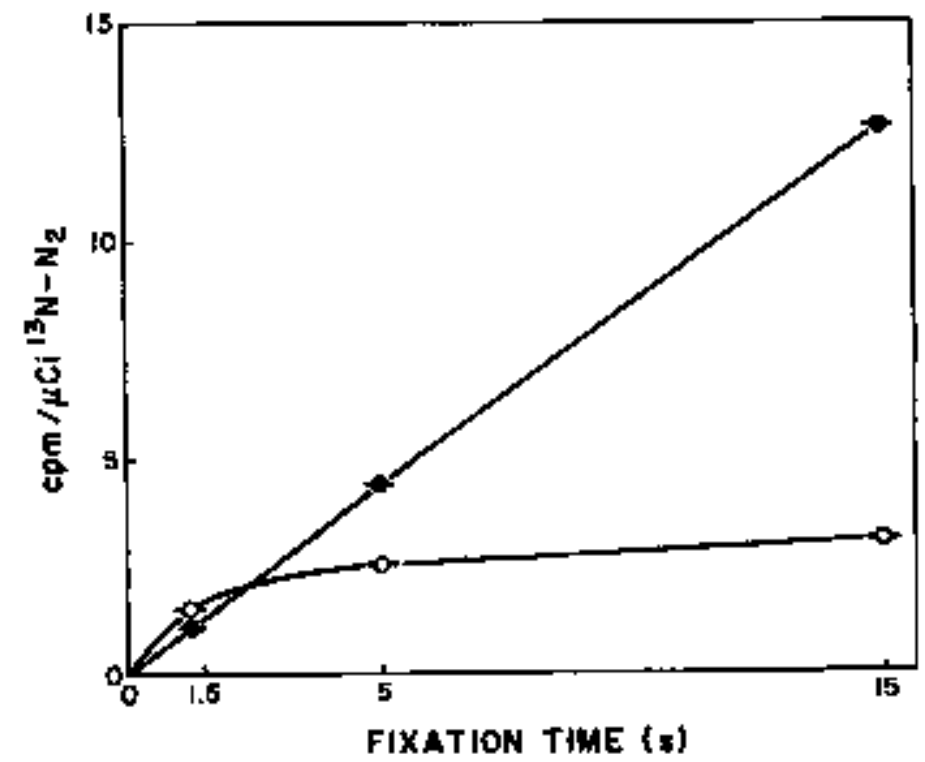

Fis. 3. Time course of incorporation of ${ }^{13} \mathrm{~N}$ into pools of $\mathrm{NH}_{3}$ and amide nitrogen, after fixation of $1 \mathrm{Y}_{\mathrm{N}-\mathrm{N}_{2}}$ for 15,5 and (approximately) $1.25 \mathrm{~s}$. EIghty percent methanolic extracts were subfected to vacuun distillation at $\mathrm{pH} 10$, to determine $13 \mathrm{NH}_{3}(-0-)$, and then to steam distillation in the presence of $40 \%$ NaOH, to determine anlde-13N $\left(-\mathrm{O}_{-}\right)$. The ordinate tepresents cpm $13 \mathrm{NH}_{4}^{+}$or cpm amide-13 $\mathrm{N}$ in the fixation vial, corrected to the time of the start of fixation, and normalized to equal $\mu \mathrm{Cl}$ of $13 \mathrm{~N}$ in the vial.

Our observations demonstrate unequivocally that $\mathrm{N}_{2}$-dertved nitrogen fixed by this organism is metabolized by the glutanine synthetasemglutamate synthase pathway.

In the presence of ATP, dithiontte (Stewart et al., 1969) and light (Wolk and Wofoluch, 1971), suspenstons of heterocysts cauple fixation of nltrogen to uptake of exogenous glutamate, to forn glutamine. He shall seek to determine whether glutamine and/or giutamate move out of heterocysts as vehicles for net transfer of fixed n1trogen Into vegetat1ve cells.

\section{Referenceg}

Stewart, W.D.P., A. Haystead, and H. W. Pearson, ature 224:226 (1969)

Wolk, G, P., and E. Wojcluch, Planta 97:126 (I97I) 


\section{Envelope Polysaccharldes of Heterocysts and Spores}

L. Gardemil de Balboa, C. P. Wolk

The only known bfosyathetic process associated with gporulation which appears to differ qualitatively from processes of growth of vegetative cella is deposition of the spore envelope. The envelope, after removal of Iipld, is $68 \%$ carbohydrate by welght in $A$. cylindrica. In the same alga, the envelope produced when a vegetative cell differentlates into a heterocyst 1s approximately equal in mass to the vegetative cell, and af ter extraction of 11pid 1a 928 carbohydrate by weight.

Smith degradation (periodate oxidation followed by reduction with sodium borohydride and mild acid hydrolysis) cleaved off all branches from the envelope polysaccharides, but left the backbones intact. The backbones consist of 1,3-11nked glucose (G1c) and mannose (Man), in a ratio of 3:1. Dtsacchartdes, trisaccharldes and tetrasaccharides obta1ned from the backbone polysaccharides by partlal acid hydrolysis were fractionated by column chromatography and sepsysted by high-voltage paper electrophoresis.

The presence of both Glc and Man in oligosaccharldes derived from partlal acid hydrolysis impliea that the backbones do not consist of seporate glucan and manan chains. The fact that no di- tri-, or tetrasaccharide contains two wannosyl residuea implies that the backbones do not consist of a rendon distribution of glucosyl and mannosyl moleties. The presence of a single mannosyl residue within each of the four tetrasaccharidea implies that the backbones consiat of a repeating unit Gle $\leftrightarrow \mathrm{Gl} \leftrightarrow \mathrm{Glc} \rightarrow$ Man, an interpretation which 1. consistent with the structures and relative frequenctes of di-, tri- and tetrasaccharldes which were observed.

The diaaccharides ware Identified as GlctMan, Man $\rightarrow G 1 c$, and G1c $\rightarrow$ Glc,

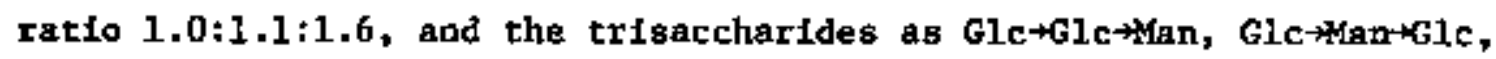
Men $\rightarrow G 1 c \rightarrow G 1 c$ and GlctGle+Glc, ratio $1.0: 1.0: 1.0: 1.0$. Because GlctMan, $G 1 c+G 1 c$, and Glc+GlctGlc were completely hydrolyzed by $\beta-g l u c o s i d a s e$ but not measurably by a-glucostdase, and because Man-Glc was hydrolyzed by B-sannosidase but not by $\alpha$-mannos1dase, we conclude that 811 of the linkages in the backbones are in the b-configuration.

We have found no differences between the envelope polysaccharldes from heterocysts and spores. As discussed above, the backbone of both consists of $B(1+3)$-Iinked giucose and mannoge with a repeating sequence of GlckGlc+Glc+Man . 
Moreover, all of their other glycosidic linkagea are present in the same frequency, within experinental error. Although it remains to be determined whether or not the branches are linked with the ame anomeric configurstions to the same ougar reoldues in the backbones of the two polygacchartdes, the evidence available to date seens sufficlent to auggest, as a working hypothesis, that the ervelope polygaccharides from the two types of differentiated cells are eveentially Identical. We propose that, If the polysaccharideg from the two sources are essentfally identical, thelr atructures resemble, to a firat approxination, the structure presented in Fig. 4.

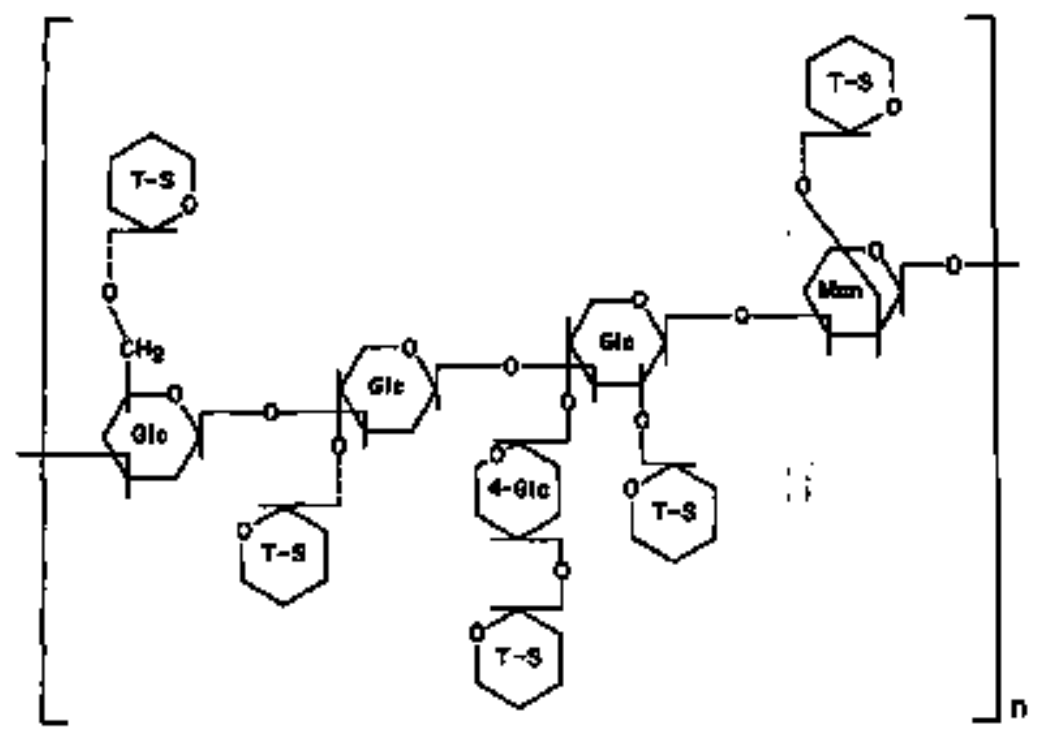

F18. 4. Posatble structure of the polysactharidea from the envelopes of heterocysts and spores of Anobaena cyilinatrica. Linkages to teruinal sugars (7-S) Indlcated by dashed atrows can be present in only certain of the "basic" units 11lustrated. On the basis of approximate stoichtometry, It may be suggested that the 2,3,4-Gle in the polysacchartde has, as regular substltuents, T-Glc and (11nked to the C-2 or C-4) Glc-(1-4)-GIc, Because the sequence of substitutiong af backhone gitcosyl residues $1 \mathrm{~s}$ unknown, an arbitraxily chosen sequence is 1llustrated. Unlinked carbons-6 are ontted from the drawing for the ake of simplification. 
Onty a portion of the mannosy residues in the backbone is substituted, and certaln of the terminal sugars are present In anounts aot stolchionetric with the backbone sugarg. Therefore, even if the sequence of substitutions of glucasyl residues in the backbone were correct, the "basic" structural unt 11lustrated would not be, in the strict sense, a "repeatigg" subuntt. It is also possible that the envelopes contaln a mixture of slightly differing polysacchaxldes, each of which has a strictly repeating subunit. 
THE PRTMARY CELL WALL GLYCOPROTETH EXTENSIN AND RELATED MATTERS

We are intereated in the structure, function and wetabolism of extensin, the hydroxyproline-rich protefn present in the primary cell walls of most green plants. The Importance of this material arises especiaj3y from the demonstration that it is a glycoprotela in which the hydroxyproline hydroxyl group is glycostdically linked to short arablnose oligosaccharides, while the serine hydroxyl group 18 glycosidically attached to galactose. Both of these glycopeptides Itnkages could function as cross links between wall polysaccharides. Thus we have postulated that the primary cell waII can be looked at as a proteln-glycan network (analogous to the peptidogiycan of bacterial cell walls) in which the extensin polypeptide plays an Integral structural role and 18 therefore also involved, directly or indirecty, In cell wall plastictty and cell growth. Most of the current work is devoted to the determination of the atructure of extensin (Including polysaccharide attachment) from cell walis of higher plants, using in vitro cell cultures. Uitimately we hope to describe how the extengin polypeptlde backbone relates to the rest of the plant cell wall atructure. For this reason we are also attempting to study the structure of soluble extensin precurgors (and other soluble hydroxyproline-rich glycoproteins), so that we can determine which polysaccharides (if any) are attached to extensin before Insertion into the wall gtructure.

\section{Extensin Structure}

(a) Solwbitization of Extensin via B-Etimination Under Semi-Aqueous Conditions D.T.A. Lamport, $M$, Caughey

He continue to study the effect of semi-aqueous alkaline condstions on the B-elinination of serine and release of hydroxyproline-rich material from 1solated tomsto primary cell walls. Although this method always solubilizes $>60 \%$ of the hydroxyproline, the chromatographis profiles vere Irreproductble, and turned out to be very dependent on the reaction temperature. Thus, ruming the reaction of $45^{\circ} \mathrm{C}$, solubitized hydroxyproline- 
rlch nacrowolecules nost of which were well retarded on U1trogel AcA54, and fractionated further on Sephadex $\mathrm{g}-50$ and by 1ao-electric focusing (pH 7-10). The amino actd analyses of these fractions are interesting because of their distinct reseablance, when written as an empirical formula, to the sur of the compostions of the tryptic peptides previously isolated fron tomato celi walla:

\begin{tabular}{|c|c|c|c|c|c|c|c|c|c|c|c|}
\hline & KYP & SER & LIS & VAL & TYR & THR & $\begin{array}{l}\text { TYR } \\
\text { DERIV. }\end{array}$ & ASP & GLU & ILU & LEU \\
\hline $\begin{array}{l}\text { Sum of tryptic } \\
\text { peptides }\end{array}$ & 27 & $\mathbf{8}$ & 6 & 2 & 2 & 1 & 2 & - & - & - & - \\
\hline G-50 Fraction I & 27 & $6.4^{\star}$ & 5.8 & 2.6 & 2.7 & 0.8 & 1.9 & 1.3 & 0.8 & 0.4 & 0.6 \\
\hline G-50 Fraction II & 27 & $5.8^{*}$ & 4.6 & 2.3 & 1.1 & 1.0 & 0.3 & 1.5 & 1.2 & 0.4 & 0.7 \\
\hline
\end{tabular}

It 18 therefore reasonable to consider the posslbility that the hydroxyproline-rlch material released by B-elfuination may be tatact or nearIntact extensin polypeptide subuntts.

\section{(b) Solubiliaation of Extensin via sodium Chiomite Oridation}

A. Hort, D.T.A. Lamport

Bolling the tomato walls for 2 hours in a $5 \%$ amsonium oxalate solution (pH 6.5) contalning a litcle sodium dithionite to prevent oxidation, solubillzes about $40 \mathrm{z}$ of the welght of the wall, although virtually all of the hydroxyproline renains with the ingoluble wall residue. Sodium chlorite oxidation ( $75^{\circ}$ for 30 winutes in $1 \% \mathrm{NaClO}_{2} \mathrm{w} / \mathrm{v}$ in $1 \%$ acetic acid) of these extracted walls then solubilizes nost of the macromolecular bydroxyproline. The materlal solubllized accounts for ca. $10 x$ of the wall dry wefght and consista alnost exclustvely of glycopeptide fragrents. These glycopeptides and peptides beve a very broad slze range, but nost of the hydroxyproline-rlch glycopeptides vold a Sephadex G-50 column. The G-50 vold contains over 50 mole percent hydroxyproline (with respect to anino actds). The peptides retarded on G-50 are much less rich in hydroxyproline and have an amino actd composition more like general cytoplasmic protelns. Fragnents of non-hydroxyproline-containing proteins 
vould not be expected to be heavily giycosylated and therefore, would probably not be large and so are retalned on G-50.

The nechanisn by which NaClo, releases protein fron cell walls is still not clear, Just as the way in which cell wall protesn is retained in the wall 1s unclear. He do know that $\mathrm{NaC1O}_{2}$ cleaves some peptide bonds, at though which ones remaing to be determined. Sodium chlorite oxtdation does not affect polysaccharides.

\section{(a) Frastionation of sodiw Chtorite solubilited Glyoopeptides}

A. Mort, D.T.A. Lamport

The glycopeptides split into two fractions when chramatographed on a Bio-Gel A.5 $K$ or A.115 M colum, a vold and a retarded peak. These two fractione were further purified by BEAE celiulose chromatography.

The large molecular weight fraction (A.5 M vofd) gives a single relatively sharp peak on DEAE cellulose. (An additfonal uronte actd peak may also elute sonewhat later if the ammorifum oxalate treatment is nat followed by thorough washing.) The uronic acids, neutral sugars and hydroxyproline co-chronatograph in this afngle retarded peak on DEAE cellulose. If this matertal is then chromatographed on a CL Sepharose 6B column there appear to be two fractions only partitally resolved. The aro retarded of the two has the compostition:

HYP $_{30}$ ARA $_{1.3}$ SER $_{7.1}$ VAL $_{1.0} \operatorname{TrR}_{0.5}$ LIS $_{2.3}$ a-aminaadipic acid 1.1 , trace amounts of other anino actids, arabiaose 157 galactoge $_{20}$

Balacturanic acid 32 glucose $_{4}$.

It is possible that the larger of the two fractione Is a slighty legs degraded fragment which contains an additional region somewhat poorer In hydroxyproline.

On an AcA22 column (fractionation range 60,000 to 1 million daltons) the DEAE retarded peak is anomalousiy retarded, eluting almost wfth the salt. This was interpreted as a gtrong interaction between the colun material and the glycopeptides. Nevertheless, there fa a very good correspandence in the elution of the hydroxyproline and the urontc acids.

After 1so-electric focusing of the DEAB retarded peak the hydroxyproline and uronlc acids again show colncidence. From all these attempts to purtfy the uronic acids from the protein we conclude that the two are probably 
covalently attached, although conclusive evidence has not yet been obtained. For example attempts to retain the protein at low pH on cation exchenge colums (CM cellulose and phospho celitulose) were unsuccessful. However so far only degradative procedures have aucceeded in separating the uronic acid from the protein. Attempta to fractionate on the basts of density In a caesium chloride gradient are planted.

The low wolecular welght waterlal released by chlorite oxidation (and retarded on an \$.5 M column) can also be ehxomatographed on DEAE cellulose giving the elution proftle in FIB. 1. Amfno acld analyses

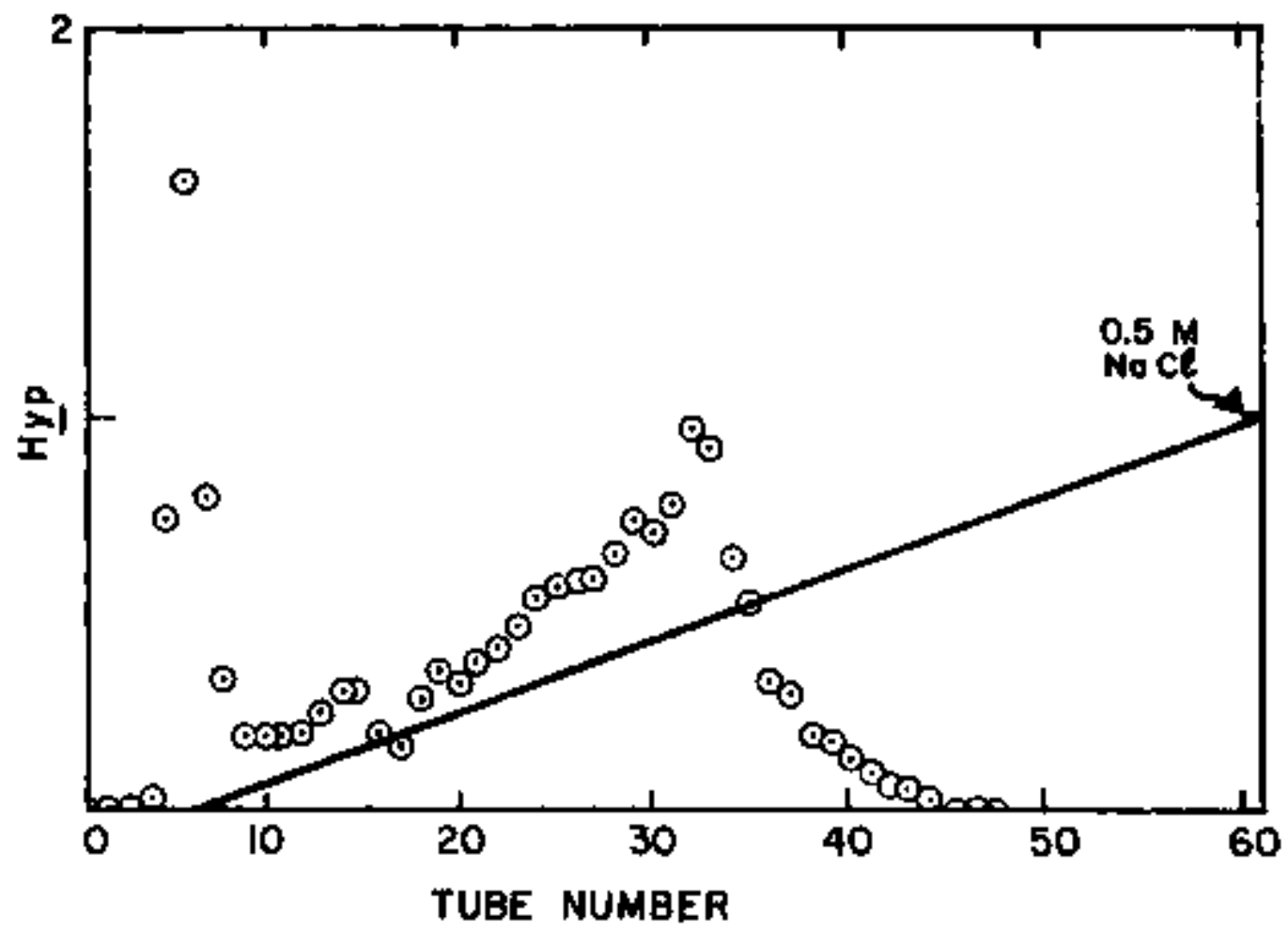

Fig. 1. G-50 voldt on DEAE cellulose pH 5.250 mil Na Acetate. Linear sait gradient $0-0.5 \mathrm{M}$. 
show that these smaller fragments differ from the larger fragmenta.

They have less serine but mach more lysine and valine, while sugar analyses show that they contain arablnose, galactose and glucose, but no galacturonlc ectd. It is quite possible therefore that there are at least two reglons In the wail protein, one rich in serine but relatively poor in lysine, while the other is richer in lysine and valine,

\section{(d) B-Elimination of Selected Frotions Obtained by Sadisn Chiomite Oxidation of Tomato Cell halla}

A. Hort, D.T.A. Lamport

In a further attempt to show covalent linkage between the uronic acld-contalning polysaccharide and the proteln, we oubjected the high molecular welght DEAE material to a B-elimination reaction in $50 \%$ DasO, $10 \%$ EtOH, $40 \% \mathrm{H}_{2} \mathrm{O}, 0.2 \mathrm{~N} \mathrm{NaOH}, 1 \mathrm{M} \mathrm{NaBH}$ at $37^{\circ} \mathrm{C}$ atirred continuously for 6 hours, followed by neutralfzation with acetlc acid. After this reaction the urontc actds still appeared in the votd volume of an A.5 M column but the hydroxyproline was retarded by a G-50 column (ca. 2 x vold). Little Information is available on the effect of base or protein under these conditions and so it is difficult to intexpret these results. It sppears that some bonds mist have been broken by the alkall as the game fraction totslly deglycosylated by liquid HF volds a G-50 colum. However chls experinent does show that conditions which cleave a polysaccharide fron serine restdues in the protelo do allow separation of the tronic actds fron the proteln.

\section{3uluble HydroxyproI1ne-R1ch Glycoproteins fyom Higher Plants}

\section{D.T.A. Lamport, M. Ceughey}

ReIatively smatl amounts of hydroxyproline-rich glycoproteins occur solubie in the cytoplasm as well as in the growth medim of suspenston cultures of higher plants, and also as we recently discovered, In the xylem aap of the sugar maple (Aoer saachamm). We have been able to purify the peptfde component of one of these glycoprotelns uttlizing our HF-deglycogylation method (aee below). Thus the hydroxyproline-rich glycoprotein secreted Into the medium by sycamore-maple (Acep paeudoplatanus) cells normally voids a Sephadex G-100 colum. After HF-deglycosylation the deglycosylated protein has an elution volume of about $2 x$ vold and the amfo 
actd composition shows a dramatic enrichment in hydroxyproline. An even more Interesting feature now appears if one compares the amino acid composition of this protein fion the growth medium with the compoaition of a Elycoprotein abtained simply by evaporation and dialysis of sugar maple sap. Both glycoproteing have as their most abundant amino acid residues, hydroxyproline, sertne, and alanine:

\section{MAPLE SAP \\ POLYSACCHARIDE}

\begin{tabular}{lr} 
HYP & \multicolumn{1}{c}{30} \\
ASP & 23.1 \\
THR & 14.7 \\
SER & 27.0 \\
GLU & 18.7 \\
GLY & 19.8 \\
ALA & 27.8 \\
VAL & 8.6 \\
YET & 1.1 \\
ILU & 7.0 \\
LEU & 18.2 \\
TYR & 1.6 \\
PBE & 5.9 \\
LYS & 11.2 \\
HIS & 3.1 \\
ARG & 4.8
\end{tabular}

\author{
DEGLYCOSYLATED \\ MEDIUM GLYCOPROTEIN
}

30
20.5
18.6
25.8
13.5
13.3
24.1
11.4
-
6.1
11.0
0.6
5.0
8.5
3.2
3.0

These data lead to two fmportant conclusions: FIrst, the two glycoproteins, one secreted by cells in culture, the other present in xylem sap, may well be Identlas. Second, these glycoprotelns are extensin-like in their high proportion of restdues existing as hydroxyproline and serine, but distinctly unlike extensin in having so much aianine. This leads to the interesting possibility that thege glycoproteins are amphipathic - 1.e. have two distinct regtons, the hydrophilic one of which could for example be extensin per se, while the hydrophoblc reglon would contaln the bulk of the atanine. Such an arrangement of hydrophilfc-hydrophoblc domalns typifies some nembrane protelns.

\section{Hydroxyproline-Rich Glycoprotelns fron Voltox}

D.T.A. Lamport, M, Caughey

We have previously repozted that the extracellular matrix of Votvox acrtaxi is extremely rich in hydroxyproline and slyclne. This indicates the possibilty of a single prateln with a composition Intermediate between that of extensin and collagen with the rather interesting possibility that 
they are homologous protelns. Recently Kochert (1974) has commented on these data suggesting the possibllity that the glycine component night be an artifact arising from the glycylglycine present in the growth medium. We therefore re-examined some of our origlnal naterial (which had been obtained by $70 \%$ ethanol prectpitation of the growth medilm) after passage through Sephadex G-25 to remove any amal1 molecules posstb1y occluded or adsorbed durfig the ethanol precipttation step. After actd hydrolysis of the Sephadex vold fraction we reconfirmed the high glycine content, by high pressure liquid chromatography on Chromobeade c2 cation exchange columns, and by gas chrowatography of the amino actd 1sobuty1 esters as their N-heptafiuorobutyrates. Whether or not this glycine is an Integral component or just a macromolecular contaminant of the Volvox arpteri matrix 18 an important question for the future.

\section{Reference}

Kochert, G., PNAS 71:1211 (1974)

4. Chargctertation of Posglble Extengin Precursors from Sycamore-kaple Cellg

F. Nordin, D.T.A. Lamport

We considered the possibility that polygalacturonides are attached to extensin during its biosynthesis. Therefore we 1ncubated log phase cells of aycamore-maple with ${ }^{3} \mathrm{t}$-methyl-labelled methionine and ${ }^{14} \mathrm{C}$-proline, and then fractionated the organelle matrix proteins by 1go-electric focusing. Although some tractions were ${ }^{3} \mathrm{H}$-labelled, the ${ }^{3} \mathrm{H}-1 \mathrm{abel}$ was not saponiflable. This could mean that pectin to not attached to extensin during its biogothesis. Alternatively 1t might Indicate that attached pectin was methylated only very late in blosynthesis, or that there 18 extensive demethylestexification (e.g. via pectin methyl esterase) during our extraction procedures.

5. The Uge of Hydrogen Fluorfde for Deglycasylation of Glycoproteing and for Sugar Analyge日

(a) Glycoprotein Deglyoosylation

A. Kort, D.T.A. Lanport

Cell wall glycopeptides containtng galactose, arabinose and galacturonic acid are completely deglyconylated after 1 hour in liquta 
hydrogen fluor Ide at $0^{\circ} \mathrm{C}$ (Plant Researeh 174, p. 102). However this treatment does not completely deglycosylate all glycoproteins so far examined:

(i) Fatuin. According to Splro and Bhoyroo (1974) native fetuln contains three asparaginyl-1inked ollgoaaccharides; each contains 3 restdues of slalfc acid, 3 galactose, 5 N-acetyl glucosamine and 3 mannose. In addition there are 3 serine- or threonine-linked oligosaccharides each containing 1-2 residues of sialic actd, 1 galactose and 1 N-acetyl galactosamine. He treated fetuin with HF for 1 hour and then Bel filtered it on a P100 column. After this treatment the fetuln contalned approximately $\mathbf{3}$ N-acetyl glucosamine residues, 3 H-acetyl galactosamine, 1.5 galactose, 1 NANA, and no mannose. Although neutral sugars vere reduced drastically the amino sugars directly linked to the protein (Abn-GlckAc and Ser- or Thr-GaINAc) were not removed. This is egpeclally clear for galactogamine whtch is present oniy as a direct link to protein (Ser- or Tht-GaLNAc) and is entirely unaffected by $\mathrm{HF}$ at $\mathrm{O}^{\mathrm{d}}$. Thus treatuent of fetuin with $\mathrm{HF}$ at $0^{\circ}$ for 1 hour (In the absence of the scavenger anisole) released virtually no free galactosamine.

(ii) Pig submaxiltary Mucin (PSW). ThIs glycaprotein according to Carlson (1968) containg nany short oligosaccharides linked to threonine and serine residues, e.g.

Thr (or Ser)-0-N-acetylgalac cosamine-galactose-N-acetylgalactosanine.

\section{N-acetylneuramintc actd fucose}

Treatment of PSM with liquid HF at $0^{\circ} \mathrm{C}$ for 1 hour removes at least 957 of the galactose, glucose and N-acetyl neuramintc acid, although $70 \%$ of the N-acetyl galactosamine remains with the protein. This again Indicatea that HF at $0^{\circ}$ does not cleave Ser or Thr Gal NAc.

(iii) Carb Shells. Crab shells contein a mixture of chitin (poly 1-4 N acetyl-glucosamfne), pigments, proteln, and calcium carbonate. HF at $0^{\circ} \mathrm{C}$ for 1 hour partially solubilizes the shell but the sotuble N-acetylglucosamine remains polymerlc. After 3 hoturs in HF at room temperature the N-acetyl-glucosamine becones mononartc and so, with no additional hydrolygis, can be subjected to gas chromatography as the TMS derivative. As such it chromatographs wth N-acetyl glucosamine, not with glucosamine. Thtr: HF does not remove the N-acetyl group. 
Fron these experiments we conclude thet HF does not appreciably cleave giycosidic linkages of anino sugarg at $0^{\circ} \mathrm{C}$, yet does at room temperature and therefore could be very useful in elucidating the sequence and linkages of amino sugars in Blycoproteins. For exalaple th should be posstble to obtain disaccharides in good yleid with the amino sugars at their nowreducing end. It should also be possible to simplify the eluctdation of glycopeptide linkages as all the neutral sugars can be cleaved off, leaving only the one or two amino gugars attached to the peptide.

\section{References}

D. M, Carlson, J. Btol. Chem. 243: 616 (196B)

R. G. Spiro and V. D. Bhoyroo, J. Blol. Chem. 249: 5704 (1974)

\section{(b) Total Sugar Analysis}

A. Mort, D.T.A. Lamport

Some polyaaccharides such as cellulose and polygalacturonides are exceptionally resistant to actd hydrolysis, whfle the wethoda generally in use lead to losses because of incomplete hydrolysis and partial degradation of the hydxolysis products. We therefore considered the use of HF (In the absence of scavengers* to cleave glycoaidic linkdges. We conpared the yleld of wonomers after treatment of Larch arabloogalactan*t (using mannitol as inert internal standard) with anhydrous $\mathrm{HF}\left(0^{\circ} 1 \mathrm{hr}.\right)$ and $2 \mathrm{~N}$ trifluoroacetic actd $\left(121^{\circ} 1 \mathrm{hr}.\right)$ respectively, followed by gas chromatography of the alditol acetates or trimethylailyl nethyl glycosides (Table 1). From expertments in progress where HF completely solubilizes all the cell. walt sugars we con-clude that the HF technique 1s highly satigfactory espectally for analysig of poiysaccharides regletant to the usual acti hydrolytic methods.

* Scavengers, such as antigole, are normally added to the HF reaction mixture to prevent alkylation of tyrosine and other reactive amino actds by the fluorinated compounds produced during HF addition across the bonds which are cleaved.

Linn (1975) has patented a method of generating alkylated aromatic compounds by reacting them in high concentrations of cellulose in $\mathrm{HF}$. 
Table 1. Sugar ylelds from arablnogalactan as a percentage of totel velght Derivatives prepared: Alditol acetates ${ }^{*}$ TMS methyl glycosides

Treatments

$\mathrm{HF}$

100 96

2N TFA (121" $2 \mathrm{hr}$,

90

1.5 y HCl-MeOH $\left(80^{\circ} 8 \mathrm{hr}\right.$ )

$-$

70

* Based on a secondary standard

Reference

C. B. Linn, U.S. Patent 2,798,100 (1957) 
ENZ YMIC MECHANISMS AND CONTROL OF POLYSACCHARIDE AND GLYCOPROTED SYNTHESIS IN HIGHER PLANTS; CELL WALL STRUCTURE

This project continues to place major emphasis on a gtudy of the enzymic nechanlsms and control of polysaccharide synthesis in higher plants. At present, this work centers on the blosynthesis, compostion, and structure of ceIl wall polysaccharides, with speciel emphasis on celltolose blosynthesis. Work hag also been InItiated on a second, related problem, glycoprotein synthesis in developing seeds of the legimea.

Cellulose is the world's most abundent bio-organtc compound, but 1tg biosynthesis is still one of the major tnresolved problems in plant biochemistry. There are numerous claims of tn virro synthesis of B-(I־4)-glucan by enzyme systemg in plants but in many cases, either the physlological significance of the reaction or the identity of the product can be questioned. We have chosen as our experinental material the developing cotton (Gossypium hirgutum) fiber aince it offers a number of expertmental and practical advantages (see Plant Resestch 74, p. 103). This year's work in this area Included (1) a deterwination of the In vivo rate of celiulose deposition during fiber developient, (II) 吕 vivo studies using coumarin, a specffle tohibitor of cellulose synthesis, (111) a detalled characterization of a highly active UDP-glucose: glucan synthetase in cotton flbers, and (iv) a preliminary characterization of non-cellulosic glucan in cell wall fxactions 1solated from cotton fibers.

We have atso continued studies on the composition and structure of the primary cell wall of the developtag cotton fiber. This work 1s being pursued for two reasons: (i) to complement our enzymatic studies on polysaccharide synthesis in cotton fibers, and (11) with the hope that the developing cotton fiber can eventually be explotted as a model system for studying cell elongation in plants. No complete understanding of how a plant cell elongates in response to hormones can be obtained without knowledge of the atructure of the cell wall and of how that structure 18 altered during wall extengion. The cotton fibex, obtainable in suffictent quantity for biochemical analysed, is a single cell which elongates synchronously over an extended period of time. 
How the composition and structure of the fiber cell wall changes during the elongation process has been Investigated. Since cultured flbers respond to hormonea (arxin and gibberellin) ouring growth, and mey potentially be used for studies relating biochealcal changes In the wall to the process of hormone-regulated growth, we have also compared the wall composition of cultured ftbers (i.e. fibers growing on excised ovules cultured in vitro) to that of plant-grown fibers to see whether the culture system sufficientiy minics the normal developmental process to be useful as an experinental system.

The second area of investigation, the mechantsm and control of glycoprotein syathesis in higher plants, serves as a complement to the studies of cell wall polysaccharide synthesis since many of the questions we can ask with this gysten are similar to those for cell wall synthesis: What nucleotide sugars are the substrates?, Are lipid intermediates Involved?, Where are the sites of synthes1s?, What are the controls? Glycoprotein synthesis has been intensively investigated in antma1 systems, and recent evidence has shown that the carbohydrate moleties are of ten transferred to the proteln via lipid Intermediates. Glycoproteins also extst in plants, but except for one recent paper by Forsee and Elbein (1975), very 11ttle is known af their mode of biosynthesis. Vicilin, one of the major storage protelns in the seeds of legumes, has recently been characterized (Ericson and Chrispeels, 1976) and shown to be a glycoprotein with sugar composition (N-acety1glucosamine and mamose) analogous to that of many animal glycoproteins. For this resson, we are currenty studyfing the process of glycoprotein synthesig in developing legume seeds.

\section{Beferences}

Ericson, M. C. and M. Chrispee1s, Austr. J. Plant Physiol. In press (1976) Forsee, W. T. and A. D. Elbeln, I. Blol. Chem. 250:9283 (1975) 
1. Studies on Cellulose Synthesis

(a) The in Vivo Rate of Cellutose Deposition Duming Fiber Devetopment

M. Meinert, D. P. Delmer

Last year we reported values for the celluloge content of the cotton fiber wall expressed as percent of the wetght of the cell wall durting the course of flber developient (Plant Reseaxch '74, p. 105). These data showed that the cellulose content of the wall, on th1s basis, undergoes an abrupt increase between 16 and 18 days post-anthesis. During this tine, which represents the onset of secondary wall gynthesis, the percent by wetght of cellulose $1 n$ the wall increases fron $25 \%$ to $75 \%$. Recently we have adopted a new means of expresaing changer in cell wall compostition during fiber developrent. By collecting data on fiber length, fiber yields, cell wall yields, and ylelds of Individual wall components (in this case, cellulose), we are now able to calculate the content of cellulose (ar other conponents; see report 2, below) per unte length of fiber wall. Such a calculation is much more representative of absolute changes in wall composition than are values based on welght percent, since weight percent values are dependent upon the relative changes fn other fractions of the wall as well. Fig. 1 shows how the content of cellulage per nim of fiber length varies during fiber development. By takimg the firat derfvative of this plot (with corrections for increase to fiber length), we have also calculated the appareat in ysvo rate of cellulose deposition as a function of fiber age. Surprisingly, the data show that there are two peaks In the rate of cellulose deposition--one which occurs at the onset of gecondary wall depostition, and a second one which occurs much idiex, at 27 days post-anthesis. Therefore, the concept of secondary waIl cellulose synthesfs as a continuous event werits furthex exanination. 


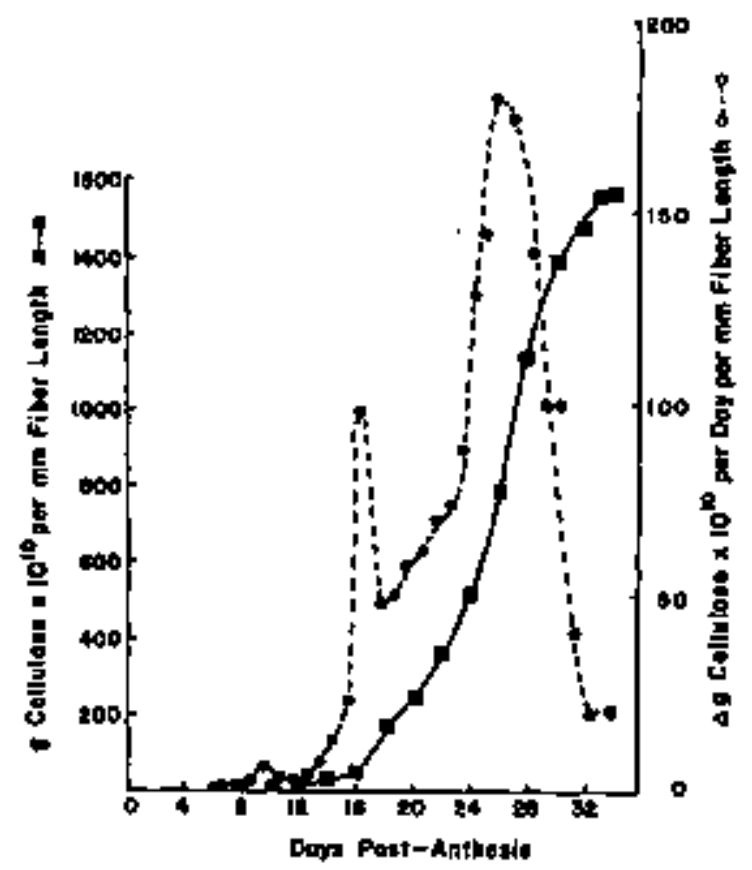

Fig. 1. Changes in cell wall cellulose content per lim fiber length during fiber development. The solid line represents the grans of cellulose per wim fiber length and was calculated as follows: gm cellulose per mm fiber length $=z$ cellulose $x$ gm cell wall per wa fiber length where gn cell wall per mo fiber length =

$$
\frac{\text { gm cell wall }}{\text { gm fibers }} \times \frac{\text { gm Elbers }}{\text { boll }} \times \frac{\text { boll }}{\text { flbers }} \times \frac{1}{\text { fiber length (mn) }}
$$

using the assuaption that the number of fibers per boll ts constant throughout development and equals 384,000 (C.A. Beasley, personal comanication).

The calculation for the apparent "rate" of cellulose deposition (dashed Iine) 1a given below and Involves a correction for changes in fiber length during elongation:

"rate" a $\frac{\left(G_{n} \times \mathrm{K}_{n}\right)-\left(G_{n}-1 \times L_{n}-1\right)}{L_{n}-0.5}$

where $G_{n}=$ grans cellulose per wil fiber length at day $n$

and $L_{n}$ an fiber length at day $n$ 
(b) The Effeat of Cormarin on the Symthesis of Frimary and Secondary Walt Cellulose in Developing Cotton Fibers

T. Skokut, D. P. De1mer

Last year we reported that coumarin, in short term in vivo labeling experiments with cultured fibers, appears to be a spectific inhibitor of cellulose synthesis (PIant Research 74, p. 11I). We have now used coumerin to fnvestigate the question of whether, primary and secondary wall cellulose are synthesized by the same or different enzyme sygtems. Cultured fibers of various ages and in varying stages of prinary or secondary wall synthests were pulsed with ${ }^{14} \mathrm{C}$-glucose \pm coumarin and Incorporation Into the cellulosic fraction wss meagured. Using 1.0 mM coumarin, specific inhtbition of celluIose synthests ranged from 62 to 85\% of control values, independent of fiber age. Thus, counarin was equatly effective in inhiblting primary and secondary wall cellulose deposition, indicating that the counarin-senstelve step in the process Is the same for both primary and secondary wall cellulose syathesis.

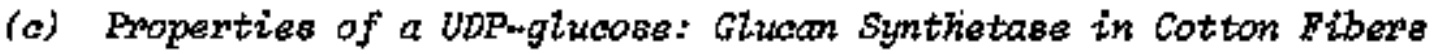

U. Helniger, C. Kulow, D. P, Delmer

We reported, in Plant Research 74 (pp, 107-110), the presence of an active glucan synthetase in cotton fibers which uses UDP-giucose as substrate and which has the unususl property of requiring both celloblose and UTP for activity at low substrate concentrations, while requiring only celloblose for maximal activity at high substrate concentrations. The activity could be measured efther tsing a detached fiber assay (see DIsat Research '74, p. 107 for descrtption) or in toolated nembrane preparations. Those results were preliwinary, and at that time we had only limited fnformation about the kinetlc properties of the enzyme and did not yet know the linkages of the glucose restdues in the glucan, although it resembled cellulose in its solubilfty properties. This year we have devoted a major effort to a detajled characterization of this enzyme.

The kinetics of the reaction, ag asgayed fn detached fibers, have been studied In detail, Including experfments degigned to measure optimal cation requixements $\left(\mathrm{Mg}^{++}\right.$at 5 gl gives optimal activity), optimal cellabiose concentrations ( 5 mif), optimal UTP concentrationa 
$(0.6 \mathrm{mM})$, and optimal $\mathrm{pH}$ (broad optimum from $\mathrm{pH} 6.5$ to 8.4 ). Other B-linked glucosides (laminariblose or B-methyl-glucoside) can effectively substitute far cellobiose as activators, whereas a-11nked glucosides are relatively ineffective. The kinetlcs with respect to UDP-glucose concentration are complex at lower substrate concentration, indicating activation by the substrate; the range in which this activation occurs can be shifted to lower substrate concentrations by the presence of cellabtose. At higher concentrations of UDP-glucose (>0.1 $\mathrm{mN}$ ), the kinetics exhibit a more standard kichaelfs-Menton form, allowing one to calculate an apparent $\mathrm{Kn}$ for JDP-glucose of $5.0 \mathrm{mw}$ without celloblose present and $1.7 \mathrm{~m}$ in the presence of cellobiose.

The unusual requirement for UTP at substrate concentrations below $50 \mathrm{mM}$ hag been Investigated further, and we have now come up with a plausible explanation of this phenomenon: The glucan synthetase, which is stimulated - by celloblose and having a high Kn for UDP-glucose, requires high substrate concentrations for significant activity. At low JDP-glucose concentrations, the UTP serves as a substrate for another enzyne, UDP-glucose pyrophosphorylase, which converts UTP plus endogenous glucose-1-P to pyrophosphate and UDP-glucose, thus raising the subatrate concentration to activating levels. A vartecy of experiments, Including the demonstration that ${ }^{14}$ c-glucose-1-P (+UTP) can be substituted for UDP- ${ }^{14} \mathrm{C}-\mathrm{glucose}$ as substrate, fully support this conclusion.

The glucan synthetase, when assayed in detached fibers, is highly active throughout flber development (F1g, 2), having activities in the range of oux calculated rates of in plvo ceilulose deposition, and in several respects has properties expected of a true cellulose synthetase. However, decalled studies on the linkage of the product produced by this enzyre have shown that the product clearly is not cellulose, but rather a non-ce11ulosic B-linked glucan. Besults of partial actd hydrolyses, periodate oxidation, spectflc enzyme digestion, and also of methylation analyses show that the product is predoninantly a $\beta-(1 \rightarrow 3)-\mathrm{g}$ lucan. The product appears 1dentical regardless of whether it is produced under high or low tDP-glucose concentrations, either with the detached fiber assay or by Isolated menbrane preparations. Because the enzyme in so many respects resembles a cellulose synthetase, but clearly 18 not, we feel such results should serve as a caveat emptor to other workers in this fleld. 


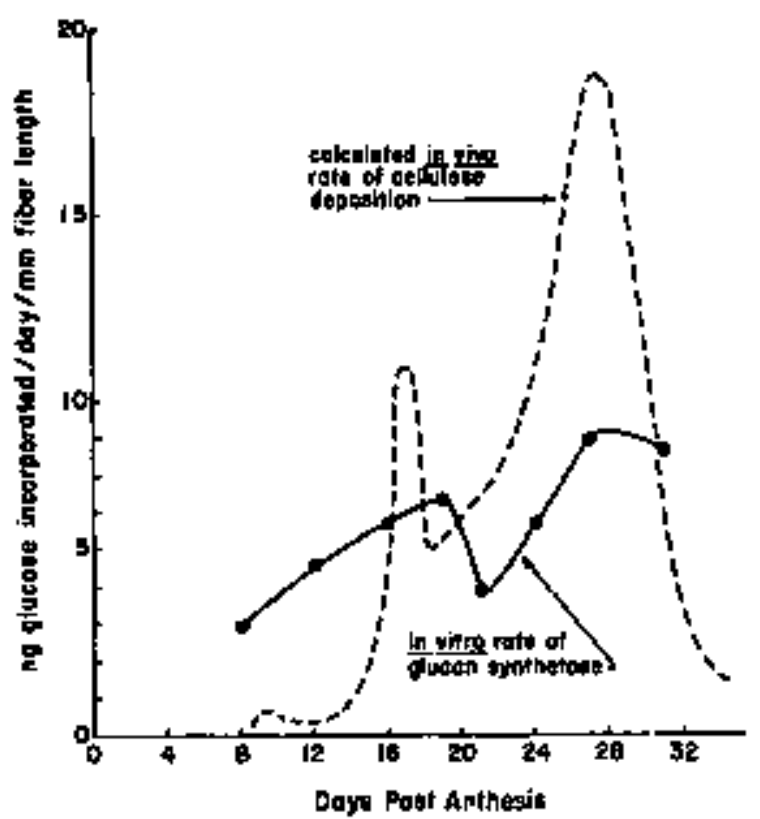

F1g. 2. Activity of UDP-glucose: glucan synthetase as a function of fiber age. Initial rates of Incorporation were assayed by incubation for $10 \mathrm{~min}$ of $50 \mathrm{mg}$ fresh weight of buffer-washed fibers in $250 \mathrm{Ll}$ of $0.05 \mathrm{~K}$ TES buffer pH 7.5 containing $5 \mathrm{mHMCl}$, $10 \mathrm{~m}$ cellobiose, and 1.0 mit JDP-14 $\mathrm{C}$-glucose ( $148,000 \mathrm{dpm}$ ). Following incubation, the fibers were extracted with chloroform/methanol, followed by successive washes in water. Radloactivity remalning in ftbers was designated as glucan product. These 1nitial rates were then converted to ng glucose equivalents incorporated per mo ftber length per day by the following formula:

(6 I.R.) $\times \frac{24 \text { hrg }}{\text { day }} \times \frac{1}{\text { D.W. }} \times \frac{\operatorname{tota1} \text { D.W. }}{\text { boll }} \times \frac{\$ \text { ftbers }}{\text { boll }} \times \frac{1}{\mathrm{~L}}$

where I.R. = InitiaI rate

D.W. = dry veight fibers corresponding to $50 \mathrm{mg}$ fresh weight flbers at age assayed

$L=\operatorname{Irm}$ ftber length at age assayed

The method for calculation of In vivo rate of cellulose deposition is given in the legend of Figure 1 . 
(d) Cetlutose Synthesis in Fea Stem Sectiona

D. P. Delmer, C. Kulat

The similartty of the glucan synthetase described above in cotton fibers to a recently reported "cell surface cellulose synthetase" in pea stem sections (Shore and Maciachlan, 1975; Shore et al., 1975) pronpted us to Investigate in more detall than that published, the 11nkageg of the product formed by this pea stem enzyme. Using techniqueg similar to those described in the previous section, we find that in our hands, the product of the reported pea stem "cellulose synthetase" when produced under conditions as close as possible to those descrtbed by Shore and coauthors, Is not cellulose, but rather a predominently $B-(1 \rightarrow 3)-1$ inced glucan, with propertles Indistinguishable by our techniques from the product of the cotton fiber glucan synthetase.

\section{References}

Shore G. and G. A. Maclechlen, J. Ce11 Biol. 64:557 (1975)

Shore, G., Y. Raymone, and G. A. Maclachlan, Plant Phys1ol. 56:34 (1975)

\section{(e) The fon-Cettutosic Gtwan of Fiber Celt Walls}

H. Meinert, D. P. Delmer

Last year (Plant Research '74, p. 185) we reported the presence of a non-cellulosic glucan component of the cell wall which Increased in content colncldent with the earliest stages of secondary wall cellulose deposition in cotton fiberg. In view of our discovery of a non-cellulosic glucan synthetage in thege fibers, we have begun to focus attention on this natural glucan in the wall as it could represent the product bynthesized In vivo by this glucan synthetare. Pralininary methylation analyseg of unfractionated walls indicate that there is a rise in 3-11nked glucose In the wall which roughiy parallels the increage in non-cellulostc glucan In the wall. Current otudies are directed at determintag whether this glucan exhibits turnover in the wall, and, if 60 , whether it might serve as a precursor to celluloge. 


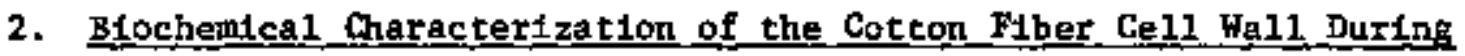
DeveIopment: The Elongating Fiber Cel1 Wall ts a Dynamic Structure

M. Melnert, D. P* Delmer

The elongating cotton fiber is a metertal in which it is posgible to examine the biochemical changes in cell wall composition assoctated with the development of one single higher plant cell throughout the entire period of elongation and secondary wall formation. Such compositfonal. analyses show that the elongating cotton fiber cell wall is a dynamic etructure. Table 1 presents a summary of the results of our conpositional analyses of cell walls of plant grown fibers harvegted at varlous stages of development.

Table 1. Sumbary of cotton fiber cell wall composition during development.

The first 1ine of figures represents the percent by weight of that conponent; the second line of figures represents the $g \times 10^{-10}$ of component per mim ftber length. ND a not deteruined. Nubers in parentheses refer to the totaled percent of analyzed componente under condttions whexe not all components were determined.

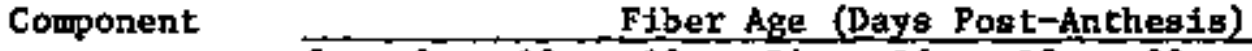

\begin{tabular}{|c|c|c|c|c|c|c|c|c|c|c|c|}
\hline & 5 & 8 & 10 & 12 & 14 & 16 & 18 & 20 & $2 \overline{2}$ & 25 & 29 \\
\hline Celluloge & $\begin{array}{l}9 \\
7.9\end{array}$ & $\begin{array}{l}10 \\
4.8\end{array}$ & $\begin{array}{l}23 \\
10.8\end{array}$ & $\begin{array}{l}24 \\
14.4\end{array}$ & $\begin{array}{l}25 \\
23.0\end{array}$ & $\begin{array}{l}31 \\
49.9\end{array}$ & $\begin{array}{l}74 \\
170\end{array}$ & $\begin{array}{l}82 \\
245\end{array}$ & $\begin{array}{l}87 \\
362\end{array}$ & $\begin{array}{l}90 \\
594\end{array}$ & $\begin{array}{l}94 \\
1363\end{array}$ \\
\hline $\begin{array}{l}\text { Neutral } \\
\text { sugars }\end{array}$ & $\begin{array}{l}33 \\
6.8\end{array}$ & $\begin{array}{l}25 \\
70.5\end{array}$ & $\begin{array}{l}25 \\
1.3\end{array}$ & $\begin{array}{l}20 \\
12.0\end{array}$ & $\begin{array}{l}17 \\
15.6\end{array}$ & $\begin{array}{l}14 \\
22.5\end{array}$ & $\begin{array}{l}12 \\
27.5\end{array}$ & $\begin{array}{l}10 \\
29.9\end{array}$ & $\begin{array}{c}9 \\
37.4\end{array}$ & $\begin{array}{c}7 \\
46.2\end{array}$ & 58.0 \\
\hline Uronte actds & $\begin{array}{l}10 \\
2.1\end{array}$ & $\begin{array}{l}16 \\
6.7\end{array}$ & $\begin{array}{l}22 \\
10.2\end{array}$ & $\begin{array}{l}21 \\
12.6\end{array}$ & $\begin{array}{l}16 \\
14.7\end{array}$ & $\begin{array}{c}9 \\
14.4\end{array}$ & $\begin{array}{l}3 \\
6.9\end{array}$ & 2 & ${ }_{8.3}^{2}$ & ND & ND \\
\hline ProteIn & $\begin{array}{l}40 \\
8.4\end{array}$ & $\begin{array}{l}24 \\
10.1\end{array}$ & $\begin{array}{l}22 \\
10.4\end{array}$ & $\begin{array}{l}22 \\
13.2\end{array}$ & $\begin{array}{l}25 \\
23.0\end{array}$ & $\begin{array}{l}21 \\
33.6\end{array}$ & $\stackrel{3}{16.1}$ & $\begin{array}{c}4 \\
78.0\end{array}$ & ND & ND & ND \\
\hline $\mathrm{Ash}$ & ND & $\begin{array}{l}3 \\
1.3\end{array}$ & $\begin{array}{l}3 \\
1.4\end{array}$ & $\begin{array}{l}3 \\
1.2\end{array}$ & $\begin{array}{l}11 \\
10.1\end{array}$ & $\begin{array}{l}11 \\
17.6\end{array}$ & $\begin{array}{l}4 \\
9.2\end{array}$ & $\begin{array}{l}2 \\
6.0\end{array}$ & ND & ND & ND \\
\hline $\begin{array}{c}\text { Total Ce } \\
\text { Wall }\end{array}$ & $\begin{array}{c}(91) \\
21\end{array}$ & $\begin{array}{l}78 \\
42\end{array}$ & $\begin{array}{l}95 \\
47\end{array}$ & $\begin{array}{l}89 \\
60\end{array}$ & $\begin{array}{l}94 \\
92\end{array}$ & $\begin{array}{r}86 \\
160\end{array}$ & $\begin{array}{l}100 \\
230\end{array}$ & $\begin{array}{l}100 \\
299\end{array}$ & $\begin{array}{l}(98) \\
416\end{array}$ & $\begin{array}{l}(97) \\
680\end{array}$ & $\begin{array}{l}(98) \\
1450\end{array}$ \\
\hline
\end{tabular}


The data are expressed both as a percent by velght of the wall (upper flgureg) or as grams of component per mn flber length (f1gures in 1tal1cs), since while relative chenges in cell wall composition ( $\%$ ) are of interent, a nore useful way of expressing the data is in absolute terms of gramp per untt length of cell wall (see above, report la).

The relative proportions of cellulose, neutral sugars, uronic acids, and protein in the cotton fiber cell wall continunlly change throughout the elongation process. When expresged ag grams component per mn ftber length, the protein and uronic actd content of the cell wall rise until just prior to the the of naxtmal rate of cell elongation (16 to 19 days post-anthesis; elongation ceases between 22 and 24 dayo post anthesis), and then sharply decline at a rate consistent with actual removal from the wall. The total neutral sugar fraction Increases continually throughout elongation; the relative ratios of the Individual sugars (rhamnoge, fucose, arabizose, xylose, mannose, galactose, and non-cellulosic glucose) continually change, wh arabtrose and non-cellulosic glucose undergotng the greatest change in content (data not shown). The Inttlal rise in total neutral sugars can be prinarily attributed to a rise in arabinose content, In later stages of elongation, the arabinose content per unit length of fiber declines; at this tine (approximately coincldent with the earliest stages of secondary wall cellulose synthesis), a significant increage in the level of non-cellulosic glucose occurs in the wall (see aloo report Ie, above).

Results obtalned for compostional analyees of cell valls derived from culture-grown fiberg indlcate that these walls are quite similar to those dertved from fibers grown on the plant, both in terus of couposition and In terws of relative changes in composition durting development. Indicating that the culture system should be quite useful for further studies on the mechaniam of cell elongation and maturation, and on turnover of wall components. However, one major difference was observed; the sequence of developmental changes which occux in the cell wall of culture-grown fibers are compressed in time relative to plant-grown fibers.

A comparison of data evallable in the literature on cell wall conpositions with our data for the cotton fiber cell wall (Table 2), Indicates that the primary cell wall of the fibers of cotton, a dicotyledonous angiasperta, ts simlar to that of other reported dicot prinary walls (and even more closely 
resembles the composition of a culcured gymosperm, Douglas fir). ThIs conclusion is further aupported by our 1.nkage analyses of the carbohydrates of the fiber cel1 wa1la as deterulned by preliminnry methylation anatyoes of unfractionated cell walls. To c1te one example, we find that fiber cell walls contalns significant amounts of 4-ifiked glucose, 4,6-lfikad glucose and terminal xyloge resfdues Indicative of a xyloglucan structure characterist1c of dicots, and lack branched cylosyl residues Indicative of the monacot arab1nosylan (Burke ett 으, 1974).

Table 2. Composition by welght percent of cell walls from vartous plant gources.

\begin{tabular}{|c|c|c|c|c|c|}
\hline & Wheat $^{I}$ & $\frac{\text { Bye Grags }}{1}$ & $\underbrace{}_{\text {sycanore }}{ }^{1}$ & $\frac{\text { Douglag }}{\text { f11 }}$ & $\frac{\text { Cotton }}{\text { flber }}$ \\
\hline $\begin{array}{c}\text { Total neutral } \\
\text { augarg }\end{array}$ & 63.1 & 73.7 & 49.8 & 37.2 & 25.3 \\
\hline $\begin{array}{l}\text { Rhamose } \\
\text { Fucose } \\
\text { Arabinose } \\
\text { Xyloge } \\
\text { Mannose } \\
\text { Galactose } \\
\text { Glucose } \\
\text { (non-cellulosie) }\end{array}$ & $\begin{array}{r}0.6 \\
0.1 \\
20.7 \\
24.8 \\
1.0 \\
12.0 \\
3.9\end{array}$ & $\begin{array}{r}0.6 \\
0 \\
20.3 \\
19.8 \\
0.1 \\
5.9 \\
27.0\end{array}$ & $\begin{array}{r}3.1 \\
1.3 \\
21.0 \\
7.6 \\
0.3 \\
12.8 \\
3.7\end{array}$ & $\begin{array}{r}2.5 \\
1.0 \\
12.7 \\
5.0 \\
0.5 \\
7.6 \\
7.9\end{array}$ & $\begin{array}{l}1.9 \\
0.3 \\
8.2 \\
2.6 \\
1.0 \\
4.3 \\
7.0\end{array}$ \\
\hline $\begin{array}{l}\text { Cellulose } \\
\text { Uronle acids } \\
\text { Protein } \\
\text { Hydroxyproline }\end{array}$ & $\begin{array}{l}14.0 \\
12 \\
11 \\
0.14\end{array}$ & $\begin{array}{l}13 \\
7 \\
7 \\
<.05\end{array}$ & $\begin{array}{l}23 \\
13 \\
10 \\
2.0\end{array}$ & $\begin{array}{l}22 \\
18 \\
18 \\
0.4\end{array}$ & $\begin{array}{l}23 \\
22 \\
22 \\
0.3\end{array}$ \\
\hline
\end{tabular}

${ }^{1}$ Taken from the date of Burke et al. (1974) on ce11 valls from cultured cells of these plants.

2 From plent grown ffbers harvested 10 days post-anthesis (mid-phase of elongation).

Reference

Burke, D., P. Kaufwan, M. McNeil, and P. Albersheils, Plant Physiol. 54:109 (1974). 
3. Glycaprote1 Bynthegis in Developing Cotyledons of Phageotug vutgoris

M. C. Exteson, D. P. Delnet

The enzymatic processes Involved in glycoprotein synthesis hsve been studied using extracts obtained from developing cotyledons of Phaseotus vutgario harvested at the time of active deposition of vicilin, the only major storage protein in this specles. Using crude extracts, radioactivity from GDP- ${ }^{14} \mathrm{C}$-mannose can be Incorporated into a eingle chloroform:methano1soluble product as well as into insoluble product(s) (F1g. 3). The kfnetics of these reactions, ag determined by pulse and pulse-chase experiments, are consistent with the radioactlve glycolipid serving as an interuediate In the synthesia of the ingoluble product(a).

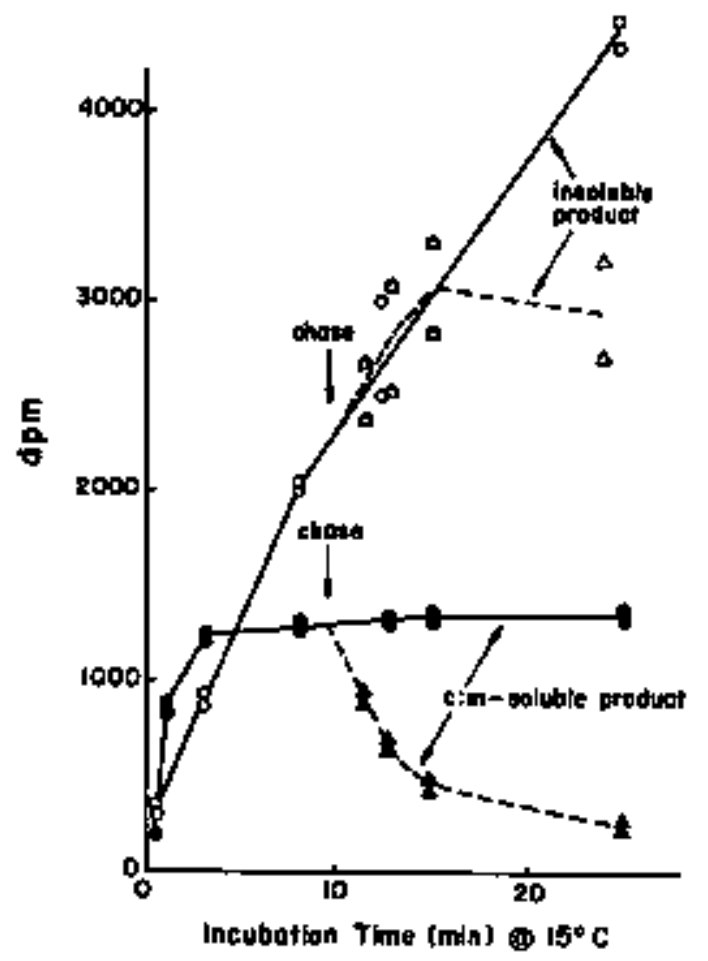

F1g. 3. Kinetics of Pulse and Pulse Chase Experiments. Reaction mixtures contained (in a final volume of $0.55 \mathrm{ml}$ ): 0.5 mil crude cotyledon extract; GDP- $\mathrm{L}^{-14} \mathrm{C}$-mannose, $3.00 \times 10^{-4}$ umol (35,000 cpm); and $\mathrm{MnCl} 2$, 5.0 Holl. Incubations were allowed to continue for vartous lengths of time at $15^{\circ} \mathrm{C}$. After $10 \mathrm{~min}, 0.1$ uno1 unlabeled $\mathrm{GDP}-\mathrm{D}$-mannose was added to "chased" aamles. Reactions were terminated by the addition of $1.5 \mathrm{ml}$ of $\mathrm{CHCl}_{3}: \mathrm{CH}_{3} \mathrm{OH}(1: 2)$. Samples were then Incubated at $37^{\circ} \mathrm{C}$ for $20 \mathrm{~min}$. After 1pccbatton, $0.5 \mathrm{ml} \mathrm{CHCl}_{3}$ and 0.5 ml $0.9 \mathrm{X}$ NaCl in $0.01 \mathrm{M} \mathrm{FCl}$ was added to each tube. Samples were separated by centrdfugation into three phases: an aqueoug phase which contalned unused aubstrate and was discarded; an Interface layer designated as Insoluble product; and an organic phare destgated as $C M-s o l u b l e$ product. Solld curves = pulsed products, broken curves a chased products. 
The characterdatics of the glycolipid, a deterained by 1 ts nobility In three different thin-layer chromatographic systems, Its restatance to alkaline saponification, and tts extreme ac1d tability, are consiatent wth tt betng a namosyl-phosphoryl-polyprenol. Treatment of the radioactive glycoliptd with tilld actd $\left(0.01 \mathrm{n} \mathrm{BCl}, 100^{\circ}, 10 \mathrm{~min}\right)$ regulte in the relenge of $91 \%$ of the radloactivity which is excluelvely recovered as ${ }^{14} \mathrm{C}$-mpmpose. The Incorporation of nannose fron GDP- ${ }^{14} \mathrm{C}$-mannose into mannolipid $1 \mathrm{~g}$ reversible by the addition of excess GDP, Indicating that the mannose is attached to the 11pid via a monophosphate linkage.

of the radianctivity in the ingoluble product(s), about $20 \%$ is pronase-digestible durlog a "pulee experfment", and about 407 is pronasedigestible after a chase with unlabeled GDP-mannose (Table 3).

TabIe 3. Solubilization of the radioactive interface product by pronase digestion.

Pulsed Interface product was obtalned frow samples Incubated for 20 ainutes with GDP- $\left[{ }^{14} \mathrm{C}\right]$-mannoae. Chaged interface product was obtained froal samples incubsted for 5 minutes with GDF- $\left.{ }^{14} \mathrm{C}\right]$-mannose and for an additional 15 minutes with untabeled GDP-mannose.

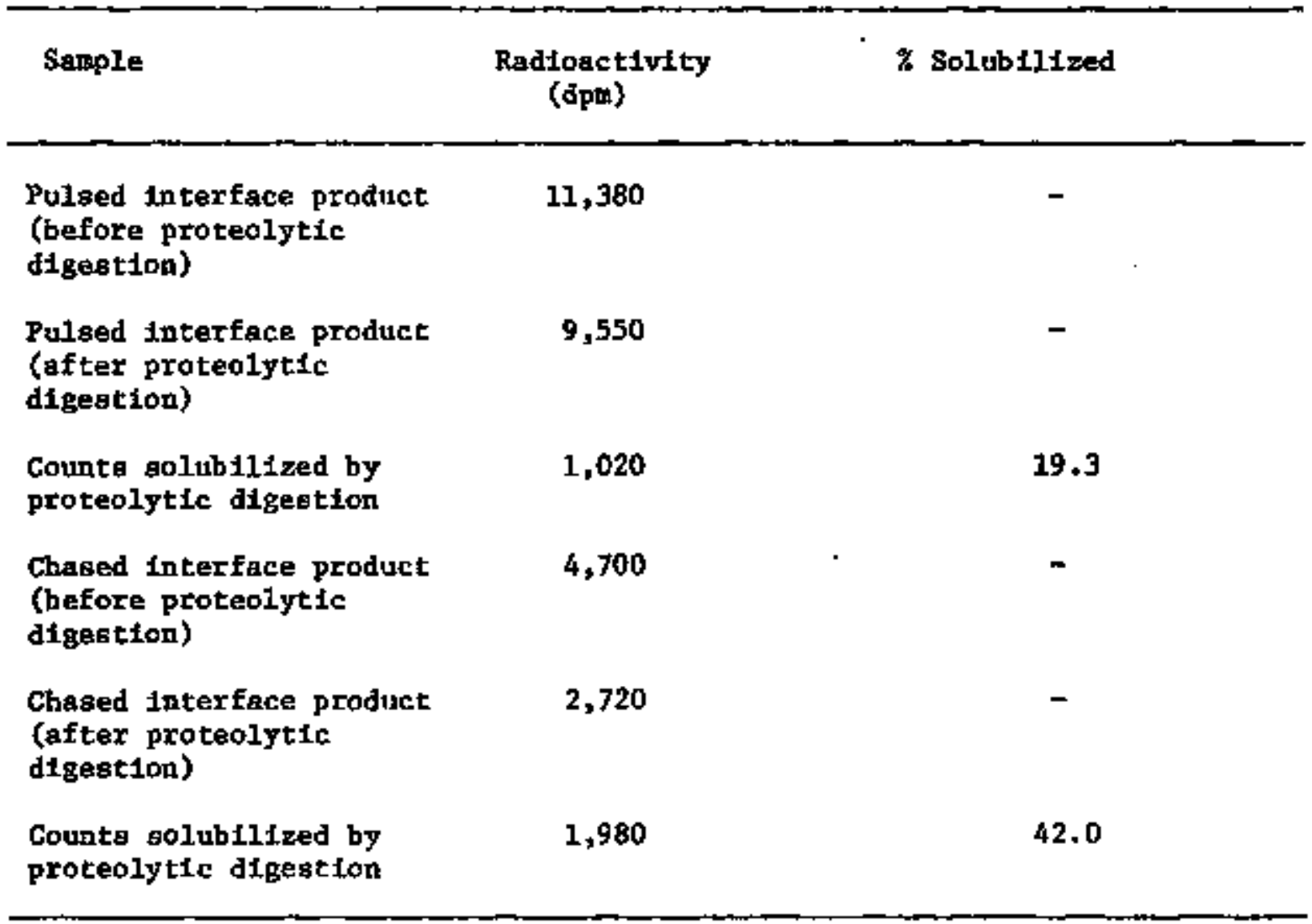


The other $60 \%$ 1в as yet uncharactertzed but cosld be a mannan. The difference In susceptibility to pronase digention in product obtatned from etther a pulae or a chase to begt explained by the presence of a radioactive 11pidoligosaccharide present in the tneoluble product fraction during the pulse; this radioactivity 18 then transferred to protein during a chase, thus increasing the percent of Insoluble product that is glycoprotein after a chnse. Thia conclusion Is supported by the fact that a radioactive product soluble only In a nixture of chloroform:methanol: $\mathrm{H}_{2} \mathrm{O}(1: 1: 0.3)$ may be extracted from the inooluble regidue obtalned during a pulse, but this radioactivity decreases during a chase. This product ataye at the origin during TLC 1n lipid aolvents. Thus we auggeat that this product may be a 11pid oligosaccharide, the final intermediate 1n glycoprotein oyntheals.

Prelininary daca Indicate that radioactivity from DDP-N-acety1-

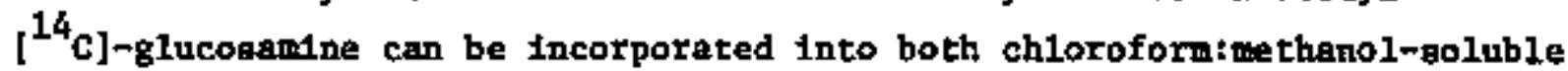
and Ingotuble products. Regults with both GDP- ${ }^{14} \mathrm{C}$-mannoge and UDP-Nacety1- ${ }^{14} \mathrm{C}$-glucosantne clearly support a role for lipld internediatas in the glycosylation of protein in this higher plant system and indicate that the mechanisms of glycoprotein syathesis in higher plants are quite simflar to those reported for mammalian systems. 
MOLECULAR STUDIES OF MAMUBRANE SYSTEMS

He Investigate phyalco-blochentcal properties of differentiating and non-differentfating blological membranes and how they respond to environmental strege. Since we have found that the mentrane 1iptd flutdity of Mycoplanmas Is regulated and kept virtually constant deaplte changes of growth temperature and food supply, we henceforth have to ask the question whether the membrane Iipfd fluldity 18 regulated during norphogenetic modifications of the nembrane, or during adaptive changes of the cell exposed to environmental atress. Therefore we are continuing to study the almple membrame from Mycoplasmas which ean gerve as a valuable model aystem to underatand mechanistically how membranes of eucaryotic cells function. Morphogenetic alterations of the plasma membrane are invegtigated in the aquatic fungus Blastoatadietla emersonit.

As in previous years we continue to study fast photoproceseas in the photosynthetic light transducer. To invertigate such photoprocesees, the entsgion of delayed light is recorded after turning off the exciting light. The delayed light intenstty at a particular point in tfme eeens to depend on an energfzed state of the chloroplast nembranes.

\section{Membrane Potential of Thermoplama aoidophiza}

J.-C. Hsung, A. Haug

Thermoplaema aoidophila is a mycoplasma-like organlem which growe optimally at $59 \mathrm{C}$ and $\mathrm{pH} 2$. We demonstrated previously that the Intraceliular pH of this organism is close to neutral as meagured by the distribution of a wenk organic actd, 5,5-dimethyl-2,4-oxazolidinedlone, across the plasms membrane. We had also demonstrated that the pll gradent 18 naintajned passively by a Donnan equilibrium. Now we have demonatrated that part of the pH gradient Is nalntalned by a nembrane potential. The potentlal was measured by the distribution of radioactive $\mathrm{KS}^{14} \mathrm{CN}$, which almost completely dissociates at $\mathrm{pF} \geqslant 2$. The measuzed membrane potential 1 les between 105 and $118 \mathrm{mV}$, positive inside the cell. Increasing the external KSCN concentration to $0.01 \mathrm{~N}$ with cold $\mathrm{KSCN}$, the potentlat is lowered to $55 \mathrm{mV}$. When the external pH is changed to $s+x$, the potentlal to practicaliy diminished to valueg smaller than $15 \mathrm{mV}$. These regults show that at least part of the pH gradient across the cell membrane is maintalned by a non-metabollc menbrane potentfal. 
2. Thermotropic Yesomoxhism and Membrane Liplds in the Hambrane of Thermop Lasma acidophita

I. I. Yang, H. Weller, A. Haug

As part of 1 ts adaptation to growth at different temperatures, Thamoplasad acidophiza apparently adjusts certa1n physico-blochemlcal parametere of 1ta cell membrane. Cella were adapted from growth at $59 \mathrm{C}$ to growth at $37 \mathrm{C}$, and the temperature dependence of membrane 1iptd fluidity of lsolated cell membranes and menbranes of Intact celle from adapted and non-adapted cells was studied by paramagnetic spin probes. Regardlegs of growth tewperature, two menbrane lipld phase traneitions can be observed, one below $25 \mathrm{C}$, and one at about $45 \mathrm{C}$. The nembrane lipld fluidity throughout this temperature range depends, however, on the growth temperature. The low cempersture transition (F1g. 1) Increases with Increasing $\mathrm{Mg}^{2+}$ or $\mathrm{Ca}^{2+}$ concentration of the cell

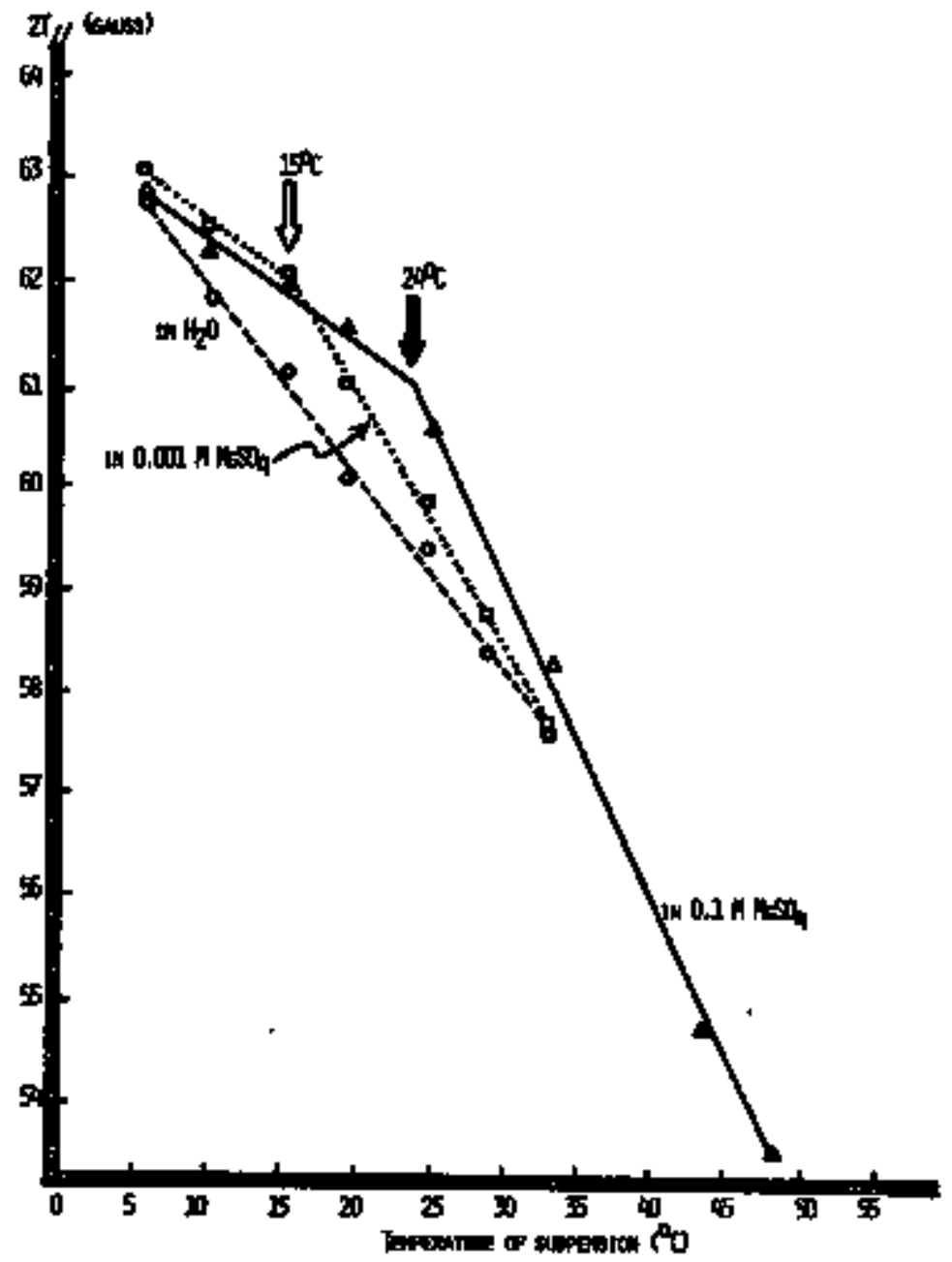

F1g. 1. ESR-determined glcroflufdttes for 1solated T. aoidophila cell membranes guspended in varloue concentrations of $\mathrm{Mg}^{2+}$. Cells grown at 56 c. 5-N1troxyl-stearate spin label. 
suspension. In the presence of bivalent Long the nembrane becomes wore rigid, the permeability of the cell membrane le probably impaired, and the activity of membrane-bound enzywes may possibly be modified.

There are leas 11poproteins and glycolipids in membranes 1solated from cells grown at $37 \mathrm{C}$ than in membranes from cells grown at the higher tewperatare. Cells grown at these two temperatures differ with reepect to two najor and several minor protein bands a deternined by gel electrophoresis. Both types of cells contain a membrane-bound ATPase which has a pH optimin in the neutxal region. This enzjwe may therefore face the cytoplasm. All phospholipids are choline positive as determined by thin-layer chromatography.

\section{Physico-Blochemical Properties of Developing Zoospores from Blastocladiet la emsreonit}

R. Leonards, A. Haug

Menbranes from the unfflagellate zoospore of the aquatic fungus Blartoctadielta emsroonit are at a higher level of organization than those from dycoplasmas. These zoospores allow a study of alterations in membrane 1ipid flufdty duriog cellular developnent. It is already known that ultrastructural and phystological changes occur during the developont of this cell, and also that these changes can be appreclably affected by enviromental factors. In the past year we refined the techntque for growing cells of Blastootadiella in large, synchronous batch cultures. Select1ve 1solation and spin labeling of zoospore plasma nembranes is being attempted in order to study blochemlcal propertles of membrane components, physico-chenleal parameters of the mentrane, and posstble control mechanisms of membrane liptd fluidity during morphogenesis.

\section{Mterogecond Delayed L1ght Egigaton and Ion Accumulation In Spinach Chloroplasts}

A. Haug; D. Be11, N. E. Good (MSU Department of Botany and Plant Fathology)

Delayed light enfssion is belleved to originate from a back reaction. of photochemical speclea of photosystem II. After turning off the exciting light, nanosecond and microsecond delayed 11ght originates in photosystem II, stmiler to slower components of delayed light. We had demonstrated previoualy that delayed light is not a fagt component of prompt fluorescence. The 
persiatence of the photochemical back reaction for millisecond delayed 11ght, as detected by delayed light as a probe, seems to be dependent on an energized state of the chloroplagt nembranes, which in turn is closely related to their ability to nake ATP. Previous experiments had shown that anmonia concentrations wich uncouple phosphorylation from electron transport increase silghtly the enisston of delayed light in the millisecond region. Other uncouplers nearly abolish millieecond delayed light emlagion. It appears that an increased membrane potential io involved in the enhancement of delayed light erission in the presence of ammonia.

In order to obtafn further Insight into the relationghips between delayed 1ight enteglon and membrane potential, we atudied posstble correlations in the microsecond region of delayed 1ight emisston. We found that virtually all uncouplers enhance the intengtty of microsecond delayed light. A posstble explanation lies in the avallability of back-reacting spectes in the presence of the uncouplers tested. Add1tional btudies are required to elucidate the mechantam(s) Involved In the enhancement of werosecond defayed light eniseton. 


\section{SENSORY TRANSDUCTION IN PLANTS}

This project is directed toward an understanding of the mechanisng whereby Information concerning the state of the environdent is recelved by an organiss. Toward this goal we are studying the sequence of events In Infocmation acquigition through non-visual light reception or the meagurement of temperature.

Our work on 1 ight reception is directed at the Identification and 1galation of the photoreceptor pigment controlling the mmerous phyolologica1 responses collectively known as the "blue-11ght" repoonses becalse the action epectra for these responses show a maximum in the blue regton of the spectrun, from 450 to $480 \mathrm{~nm}$. Th1s problem is being approached in two major ways: (1) We are proceeding with the 16olation and puriflcation of the components of the "blue-1ight" photoreceptor pigneat syaten from the cellular slime nold, Dictyostetizm discoideron. This piguent system exhfbits a light-induced absorbance change, the action spectrum for which ta simflar to the "blue-11ght" action spectra. (11) wuch of the recent data concerning the "blue-light" photoreceptor pigment are most enstly interpreted baged on the hypotheslo that the pigment is localized (at least in its active form) on the plasma mabrane. We are therefore working to isolate and spectrally characterize purtfied plasma metibranes from "blue-light" responding organistes .

For our work on tharmogengory transduction, we are also ueing Distyoatetivm the pseudoplasmodia of which are positively thermotactic. Oux work Includes: (t) the development of the conceptual baste for the etudy of the sensory transduction of a parameter (heat) which 18 Inherently non-apeciftcally absorbed; and (1i) the measurement of characteristics of the therwotransducer mechanfem to permit an identification of the thermotransducer. 


\section{Photosensory Fransduction}

(a) Photoreducible Cytochrome b of Dictyostelizon

K. Manabe, $x$. Poff

Foff and Butler (1974, 1975) and Hunoz and Butler (1975), have degcrlbed the photoreduction of a specific $b$-type cytochrone for whtch the action spectra are similar to action spectra for the physlological blue IIght responges. Tila similarity of action spectra to taken as evidence that the photoreceptor pigment for the reduction of the cytochrome is a flavin. The present work was undertaken to purffy the $b$-cytochrome in preparation for adding flavin to the $b$-cytochrome to recongttute the postulated system in vitro.

The procedure used for purlfication of the b-cytochrome is given in Table 1. Using ammonfum sulfate precipitation, gel filtration by Sephadex G-100, DEAE chromatography, a second gel filtration by Sephadex G-100 and finally chromatography over brushite, the cytochrone vas puriffed about 1,900 fold. The ratio of abeorbance at $280 \mathrm{~mm}$ to absorbance of the Soret peak of the oxtdized form of the final preparation was 0.3. A room temperature absorption spectram of the cytochrome shows peaks in the reduced form at 556-560 $\mathrm{nm}, 528 \mathrm{n}$, and $424 \mathrm{~nm}$, and in the oxidized form at $413 \mathrm{~nm}$. Spectral analysta of the pyridine haemochrone formed from the final preparation indicateg that the cytochrome has a non-covalently bound heme. The moleculer weight of the cytochrome ta 14-17 $\mathrm{K}$ by gel filtration and SDS gel electrophoresis.

Preliminary data Indicete that the purtified $b$-cytochrowe is reductble by light in the presence of added mot or added crude flavoprotein from Dictyotelizm in the presence of an electron donor such as EDTA Or MADH. 
Table 1. Purlfication of the photoreducible b-type cytochrome of Diatyostetizon discoidewn

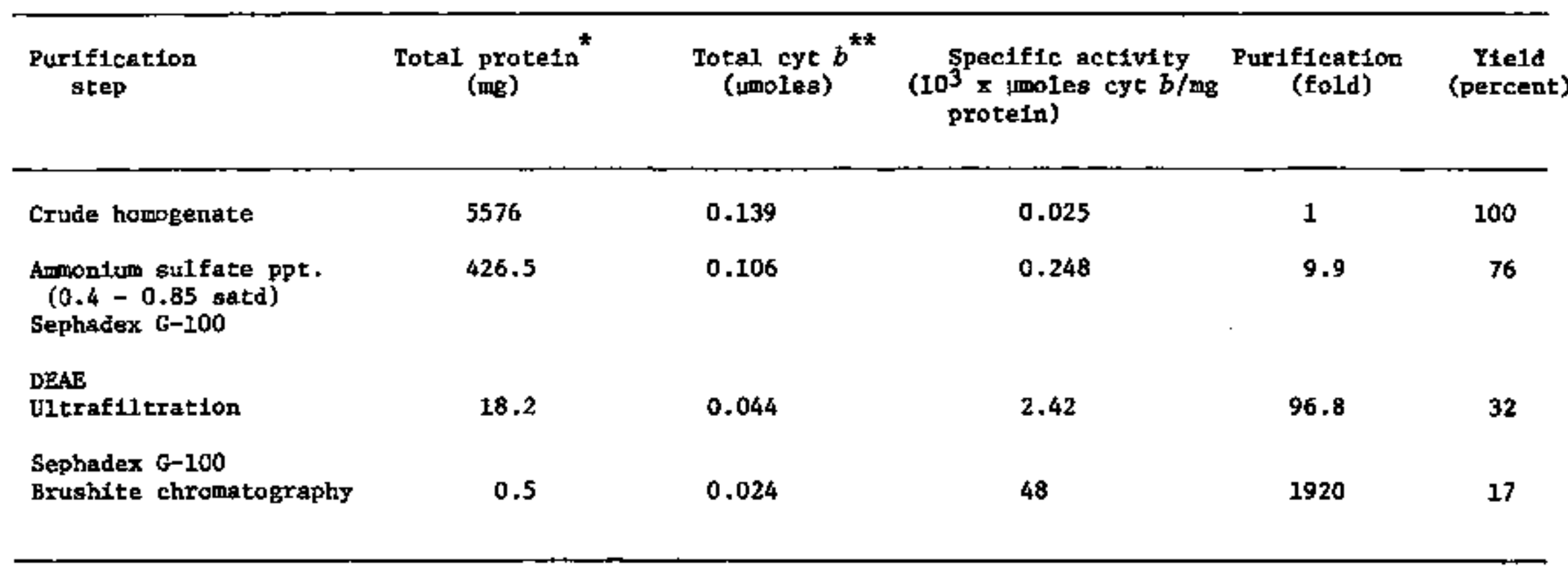

* Proteln was assayed by Lowry method.

** Extinction coefficient of a peak of the reduced form was presumed to be $25.6 / \mathrm{my} / \mathrm{cm}$. 


\section{Beferenceg}

Munoz, V. and W. L. Butlex, Plant Pbystol. 55:421 (1975)

Poff, K. I. and W. I. Butler, Nature 248:799 (1974); Plant Phygtol. 55:427 (1975)

\section{(b) Light-indwoed Absonbanoe Changes in Com Coteoptiles}

R. Kanabe, R. Poff

We have sought blue Iight-1nduced absorbance changes in coleoptiles of corn, selecting this material because corn has frequently been used in phototropism experiments and there 1s a large amount of Information on the Isolation of aub-cellular organelles fron corn coleoptilea, and because bIue IIght-Induced abeorbance changes have not previously been described in materlal from flowering plants. Coleoptiles grown in darkness show blue light-Induced absotbance changes identiflable as phytochrome changes. These may be decreased by an incubation under Fed 11ght, or circunvented by trangforming the phytochrome with red 1ight prior to Irradiation with blue light.

Coleoptiles tncubated under red light show absorbance changes 1dentifiable as the protochlorophy11-to-chlorophy11 photatransformation. This can be cfrcumented by transforming all of the protochlorophyll with red light prior to Irradiation with blue light.

coleoptiles trested in such a manner that nelther the phytochrome phatotransfornation nor the protochlorophy11-to-chlorophyl1 phototrangformation can be tnduced by blue light (priox exposure to red light) show a bluse light-taduced absorbance change. This light-induced 1ncrease in absorbance at $420 \mathrm{~nm}$ does not correspond to the blue light-induced absarbance change thought to be correlated with the "blue-1ight" photoreceptor pigment in Phycomyces (Poff and Butler, 1974), and Newrospona (Munoz and Butler, 1975). 


\section{References}

Munoz, V., and W. L. Butler, Plant Phye101. 55:421 (1975)

Poff, K. H., and W. I. Butlex, Nature $248: 799$ (1974)

(c) Inhibition of Thototropio Responses of Com coieoptiles

ฟ. Schmidt, P. Ftiner, K. Poff

The queetion of the 1dentity of the photoreceptor (flavin vexsus carotenold) for the phyatologfcal blue light responses auch as phototroplem has not yet been anewered satisfactorily. In essence thile results from the fact that no single avenue of investigation can provide a definttive answer to such a question; the answer will be dertved from the results of diverse experinents. We have extended the work by Hart and Filner (Plant Regearch '67, p, 28-30) who used inhtbitars spectflc for phototrop1st in corn beedings to obtain further information on the Identity of the photoreceptor plgment of phototropian. Potential Inhtbitars were applied in aqueous solution to the roots of $14 \dot{4} \mathrm{hr}$ dark grown corn seedifngs for one hour before application of the test atinulus (11ght, gravity). The photatrople atimulus consiated of a weak $\left(-3 \mathrm{fl}^{\mathrm{t}} \mathrm{cm}^{-2}\right.$ ) blue (440 nim defined by interference filter with a $10 \mathrm{tm}$ half-band) hor1zontal light beam for $6 \mathrm{hr}$ applied to the vertical coleoptile. In the case of dual beam trradtations, a second monochromatfc 11ght beam ( $-200 \mu \mathrm{W} \mathrm{cm}^{-2}$ ) vas applied or thogonal to the blue 1ight. The geotropic atimulus wes presented by laying the coleoptile horizontal for one $h r$, and the response was then pernitted to develop In darkness for $5 \mathrm{hr}$ with the coleoptile in the vertical position.

We asgume that the paths in geotropisn and phototropiga in the game organisn (corn seedling) differ maloly in that section of the path close to the input receptor. Thus, geotropism 1a used as a control for the spectelcity of any potential Inhibitor of the photoreceptor pigment of phototropism.

Potassium iodide, phenylacetic actd and sodium azlde inbibtt phototroplsm more than geotroplem (FIg. Ia, b, c). The potential osmotic Influence of the inhibitors can be dismissed; potasatum chloride had no effect on elther geotroplam or phototropism at concentration as htgh as $10^{-1} \mathrm{M}$ (Fig. Id). Based upon the known interaction of phenylacetic 

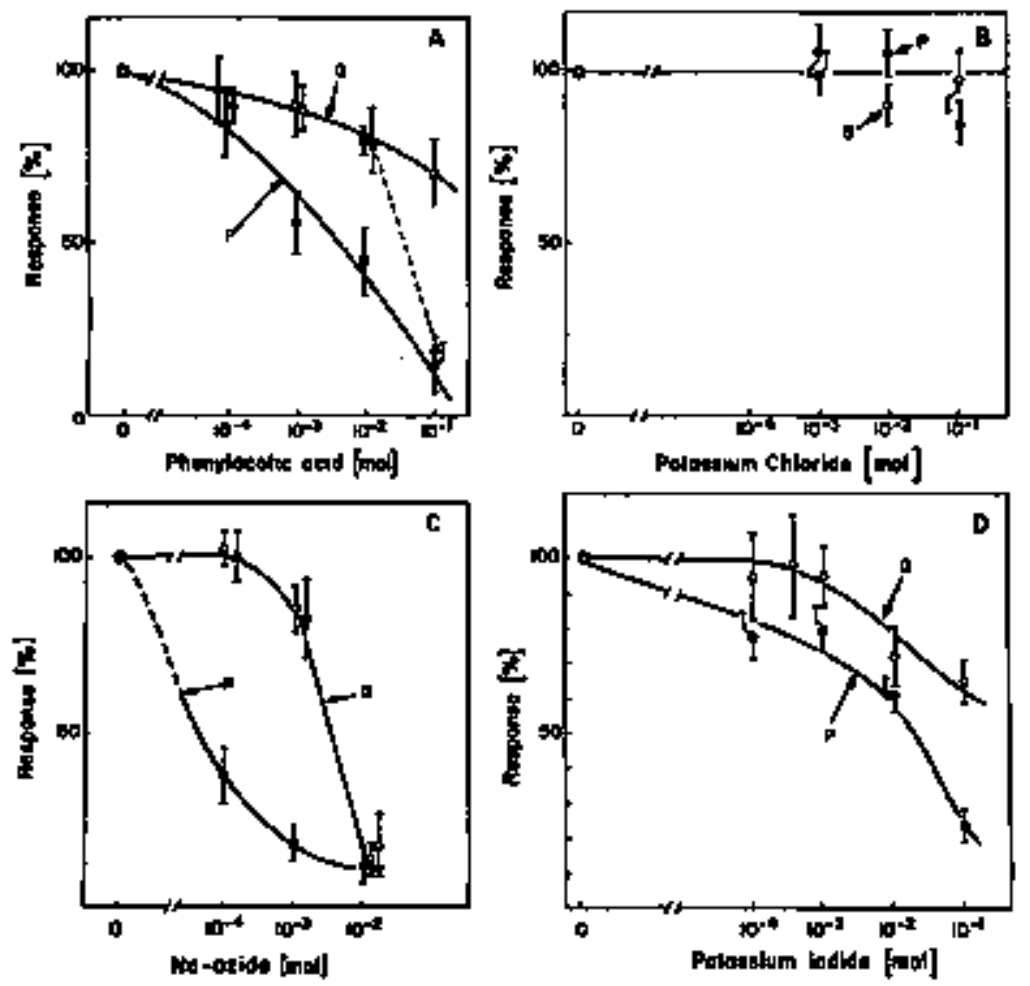

F1g. 1. Phototropism and geotrop1sm in the presence of potent1al Inhibitors. Bach point represents the mesn of measuremente on twenty coleoptiles with the error bars representing the standard error of the measurement. Reaponse expregses coleoptile bending as a percentage of that in the control.

a) Phenylacet1c acid added in aqueous solution to the roots of the geedlinB.

b) Potassium chloride added In equeous solution to the roota of the geedling.

c) Sodfum azlde added in aqueous solution to the roots of the seedling.

d) Potassium lodide added in aqueous solution to the roots of the geedling.

actd and the lodide Ion with flavins the resulte are interpreted as eupport for the hypothesis that a flavin is the photoreceptar pigment for phototroplsw. Similarly, azide has been reported to inblbit fn vitro electron transport to flavin (Schmidt and Butler, 1976), In addition to 1 te inhibitory effects on mitochooditial electron transport by cytochrome $a_{3}$ to oxygen. The speciftcity of inhibttion of phototropism by these Inhibitore may result frow localization of the photoreceptor pigment 
on the plagma membrane giving easier access to inhibitors by the photoreceptor ploment than by intraceliular flaving (e.g. mitochondrial ftavins).

Red IIght does not induce phototropism but 1nhibite the phototropic response to blue 1ight. This Inhtbitory effect has a broad action naximum (from at least 650 to $750 \mathrm{~mm}$ ) whlch may be evidence that natthar phytochrome in elther form nor protochlorophyll 18 the photoreceptor plgmant for the Inhibition. Another potential candidate for this photoreceptor plgnent is the triplet state of the postulated flavin photoreceptor for phototropism. According to this hypothesia, the triplet state of the flavin would be Incuced by blue 11ght and would be physiologically active in the phototropic response. Red light could serve to inhibit phototropisn by exciting and thus de-populating, tbis triplet state.

\section{(d) Ptama Nembrane-bound Cytochrome $b$ and Plovin in Fhyoomyoes \\ พ. Sehmidt}

The photoreceptox pigment for phototropism in Phyeomices is probably bound to the plesma nembrane and the polarity of this environment may well affect the aboorption spectrum of the photoreceptor pigment and thereby affect the action opectrum for the physlological response. Thus, spectral Identification of the photoreceptor pigment should be accompanied by subcellular localtzation of the pignent. The goal of this work was to 1solate reaspnably pure plasma membraneg from Phyoongse using the technique devised by W. Schmidt, K. Thomson, W. I. Butler and M. Delbrilck (unpubIIshed) and to characterlze these membranes through electron microscopy and visible spectroscopy.

* This work was Ialtlated by $W . S$. in the laboratory of W. 2 . Butler at the UnIvergity of Galifornka, San D1ego in cooperation with $K$. Thomson In the laboratory of M. De2brilek at the Califoraia Institute of Technology. 
The 1solation technique 1s based on gentle breakage of the nycelium through shaking on a rotary shaker with large (5 mm diameter) glass beads, mintmiztng breakage of the internal organelles. Breakgge of $15 \mathrm{hr}$ spore germilngs proceed exponentialy with wore than $95 \%$ of the mycella broken within 60 aid. Most of the organelles other than wall fragments with attached plasma membrape are retuoved by washing. Electron ntcrographs of such washed wall fragments clearly show some plasma membrane still attached to the wall.

Jltrasonic dferuption of the wall-membrane preparation permits removal of nore than 907 of the plabma nembranes, as Indtcated by comparative spectral analysis of the wall-nembrane preparation, and the resultant wall preparation and membrane preparation (FIg. 1).

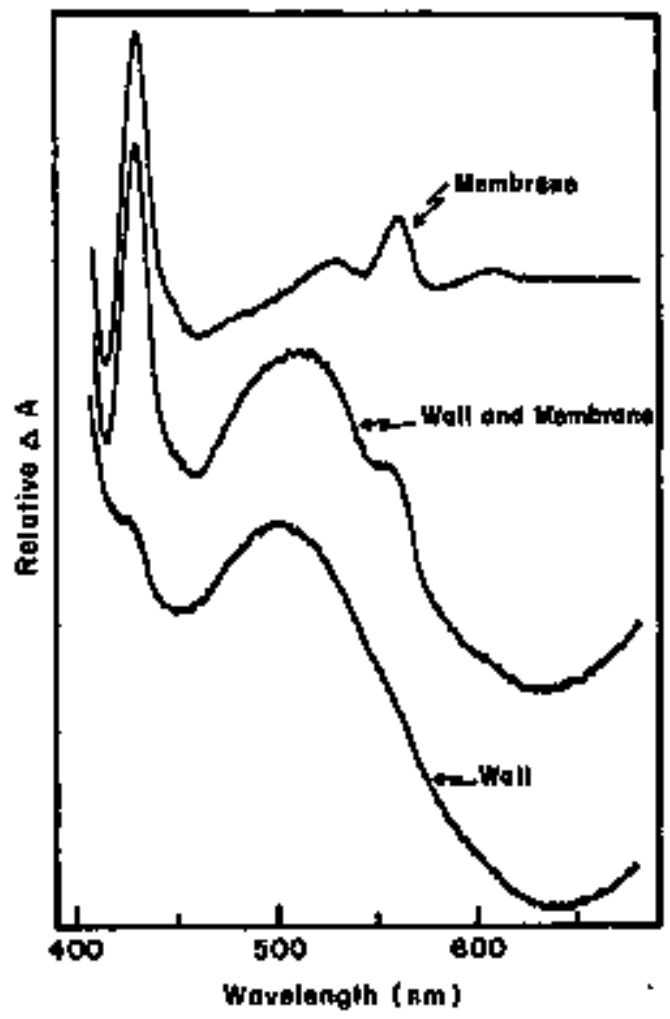

F1g. 1. Spectral characterfatics of Phyoomyces ce11 wall, wall with nembrane attached, and purifled membrane. Each spectrum is a dithionitereduced-minus oxidized difference spectrum at $22^{\circ} \mathrm{C}$. 
Following disruption, the $1 \mathrm{Kg}$ supernatant contains mainly plasma membrane vesicles which are pelleted between $8 \mathrm{~kg}$ and $40 \mathrm{Kg}$. These membranes band at $\rho=1.2$ to $1.3 \mathrm{~g} / \mathrm{cm}^{3}$ on a $\mathrm{CsCl}$ equilibrium gradient. Electron micrographs show the membrane-like structure of the vesicles from the $37 \mathrm{Kg}$ pellet (Fig. 2) and the presence of few membranes left attached to the walls from the $1 \mathrm{~K}$ pellet.

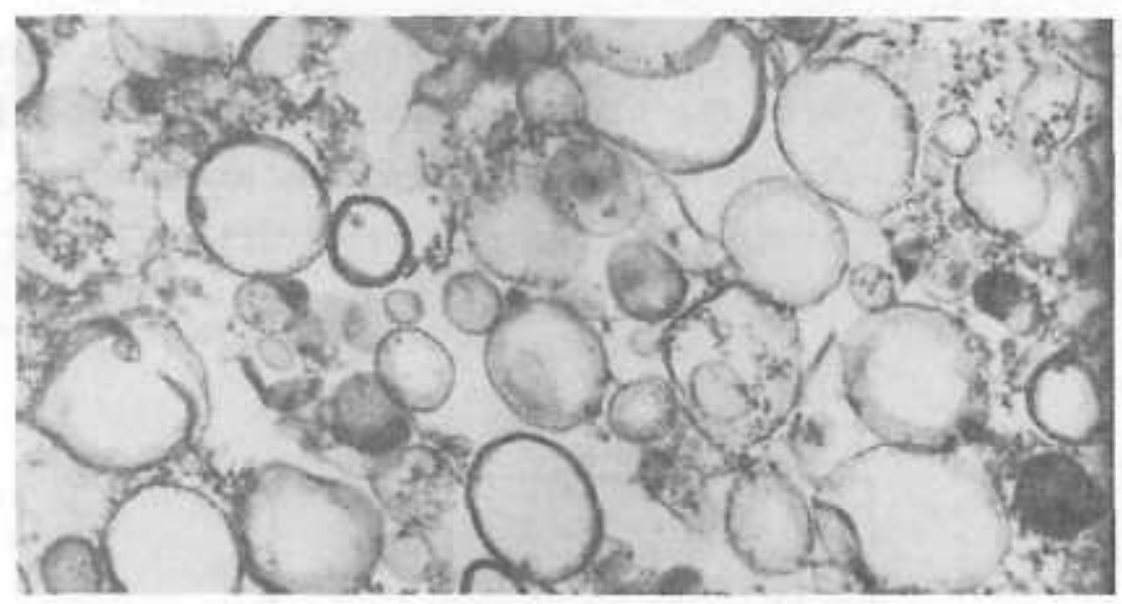

Fig. 2. Electron photomicrograph of purified plasma membrane vesicles from Phycomyces spore germlings. Preparation procedure given in Fig. 1. Fixation and staining with osmium. Final magnification $x$ 55,000.

A dithionite reduced-minus-oxidized difference spectrum of the crude plasma membrane preparation clearly shows at least one $b$-type cytochrome based on the Soret band at $430 \mathrm{~nm}$ and the $\alpha$ band at $560 \mathrm{~nm}$. A similar spectrum at $-196^{\circ} \mathrm{C}$ of the purified plasma membrane preparation (Fig. 3) shows that the $a-b$ and is split into at least 3 bands, probably representing 2 or more cytochromes. In addition to the $b$-type cytochrome(s) there is a small but significant amount of flavin based on fluoresence emission spectra of a lumflavin derivative of the purified membrane fraction. 


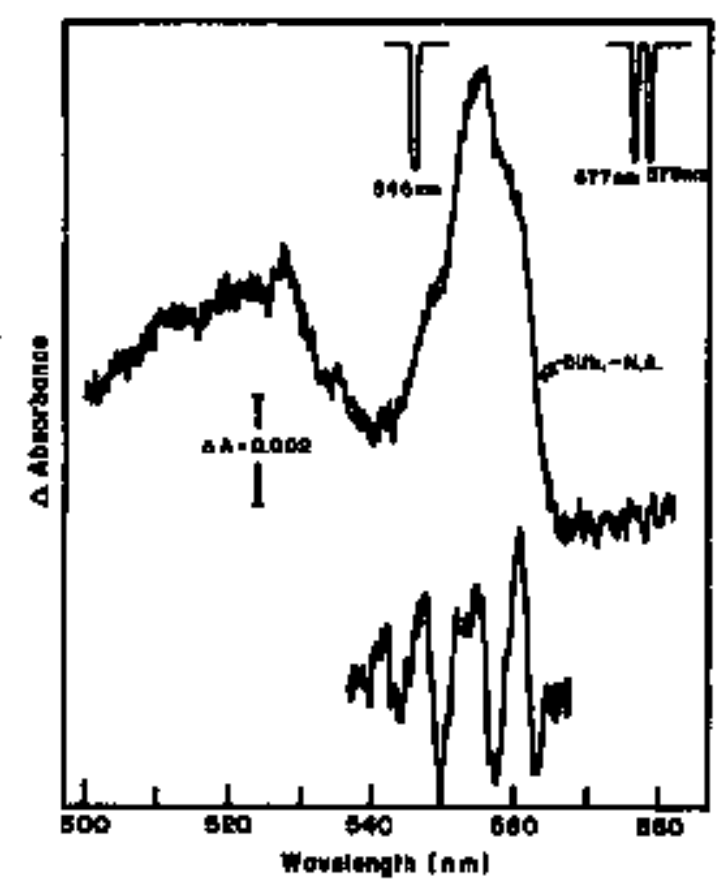

FIg. 3. Dithtonite-minus reduced difference spectrun of purified Phycombes membrane (center). A 4th derfvative of the spectrum is given below (dx - 2 na), and wavelength calibration lines fron a wercury lomp above.

(e) Light-indiced changes in Adenyzate Levets in Newroopora craear ond Diotyostetiun disooideum

B. Witaker, K. Leonards, D. Delmer, K. Poff

Delmer and Brody (1975) have reported that light Induces changeg In adenogine monophosphate (AMP) levels in Nesoroport. This fungus responds to blue light by a phase shift in 1 ts ctrcadian banding rhytha. If It could be demongtrated that such changes in AMP levels ware under control of the "blue-light" photoreceptor pigment, 1t would provide an entry Into the early physlology of the "blue 11ght" phystologtcal responses. We sought to repeat these observations, to meagure an action spectrue for any blue light effect on AMP levels, and to see whether such light-induced changes in adenylate levels ean also be found in Dictyostetim.

Adenylates were converted to ATP and meastured using the firefiy luclferin-luciferase reaction. In Nowospora, both the circadian ringthm 1n ANP Ievels and the light-induced changes in AuP levets described by Delmer and Brody (1975) could be observed but the magnitude of these 
1ight-Induced changes was not suffictently large to permt the determination of an action spectrum. No consistent light-Induced adenylate kevel changes were found in Diotyostelium. Any assay for adenylates in Diatyoatelizon 1a complicated by the rapid turnover and Interconveraton of ATP, ADP, AMP, cyclic AMP and inorgantc phosphate. We have concluded that quantitative meagurements of light effects on adenylate levela in Neuragorora and in Dictyostetiom using the luciferin-luciferase assay are presently impractical.

\section{Reference}

Delmer, D. and S, Brody, J. Bact. 121:548 (1975)

\section{Thermogensory Trangduction: Thermotaxis by Psegudoplasmodia of Dictyogtelium diocoiderm}

K. Poff, M. Skokut

We have continued our work on thermotexis in Diotyostelizm with the goal of developing a research approach which will permit the Identificetion of the thermoreceptor controlling thermotaxls. Temperaturea and/or temperature gradients may be controlled across a petri dish by vetting that dish on an aluminum block through each side of which is directed a flow of water from a constant temperature water bath. With the temperature in the center of a petrl digh kept constant at $24 \mathrm{C}$, the gradient acrogs the digh wag varied up to $10 \mathrm{c} / 9 \mathrm{~cm}$. Thermotacte orlentation Increages rapidly with an increasing thernal gradient, saturating at about $4 \mathrm{c} / 9 \mathrm{~cm}$. Pseudoplasmodia will respond easily to a gradient of $0.5 \mathrm{c} / 9 \mathrm{~cm}$ whtch corresponds to a thermal gradtent across a pseudoplesmodtum of $0.00056 \mathrm{C}$.

The temperature response curve for the migration rate was measured (RIg. I) to see $1 f$ a temperature dependent change of migration rate 18 ouffictent to explain thermotax18; $1 . e .$, does migration rate decrease wh tempexatures over the range of thermbtaxis? Migration rate 1ndeed decreases with increasing temperature, but only from 27.5 C to $29 \mathrm{C}$. Over the temperature range for thermotaxis (22 c to $28 \mathrm{C}$ frow $\mathrm{Fig}$. 2) there is no decrease in mfgracion rate wtth increasing temperature. 


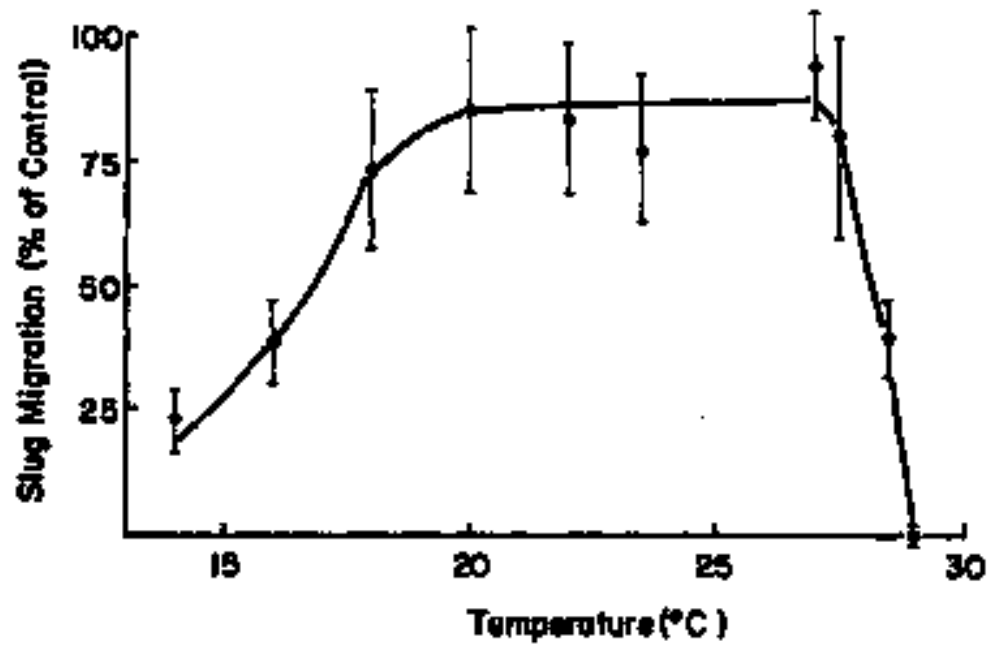

F18. 1. Relative slug nigration rate ( $z$ of a control at $23.5 \mathrm{C}$ ) as a function of temperature.

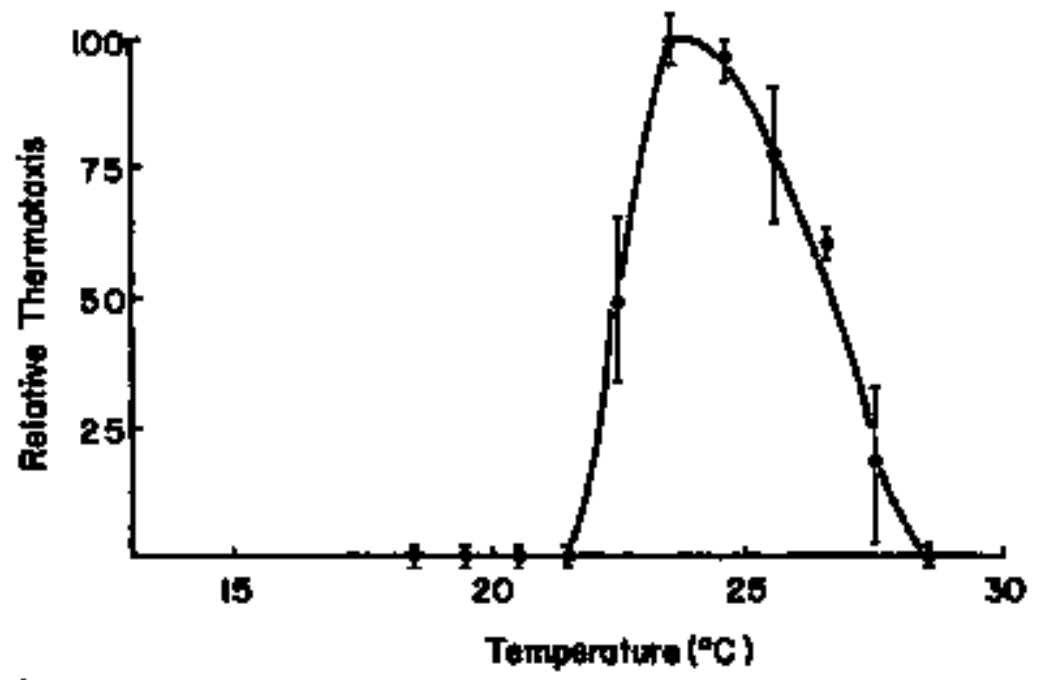

F1g. 2. Relative abiltty of pseudoptasmodia to regpond to a $0.1 \mathrm{c} / \mathrm{cm}$ thermal gradient as a function of the widpoint tehperature of that gradient. 
Thermotactic orfentation was also measured with a constant thermal gradient $(0.11 \mathrm{c} / \mathrm{cm})$ a a function of the widpoint temperature of the gradient. The results (F1g. 2) show that pseudoplagnodis are thermotactically sensitive over the temperature range from 22 to $28 \mathrm{C}$ but not above or below the range.

The total range for thermotaxla is thus leas than $6 \mathrm{C}$. The low thermotactle sensitivity over the temperature range fron 19.5 to $21.5 \mathrm{C}$ (FIB + 2) where migration rate 18 relatively unimpaired (Fig. 1) Io evidence that thernotaxis does not operate via a general thermal effect on the metaboliam involved in migration. The narrow response range for thermotaxis is indicative of a single spec1fic trangltion belug used as the thermosensory transducer .

One possible transition which could be used as a thermosensory transducer 1. a change In flutdity of a 11p1d component of a cellular menbrane. Such a transition might be expected to occur at a different temperature if the cells were incubated at that different temperature long enough for the membrane liptas to be modtfied by the celis. The cells used to form the pseudoplasmodia, the therootactic aensitivity curve of which is plotted in Fig. 2 were raised at $23.5 \mathrm{C}$, and thernotactlc semsitivity was naximal at $23.5 \mathrm{C}$. We measured such a curve for cells grown at $20 \mathrm{C}$ and found the curve to be shifted to lower terperatures by $1 \mathrm{C}$. The cells grown at $20 \mathrm{c}$ were developed for $16 \mathrm{hr}$ at $23.5 \mathrm{C}$ before plating to determine thermotactic sensftivity, and the $16 \mathrm{hr}$ Incubation at $23.5 \mathrm{C}$ may account for the $1 \mathrm{C}$ curve shift Instead of the anticlpated $3.5 \mathrm{C}$ shift.

These data are conglstent with the hypothesis that the thermotransducer is a speciflc aubstance or structure such as a lipid in a membrane natrlx, and that this substance (11pld) undergoes a phase transition over a relatively narrow temperature range. 


\section{REQULATTON OF FORMATION OF PROTETN COHPLEXES AND ENZMES IN HIGHER PLANT CEILLS}

Tro key kinds of processes which occur during development of eucaryotes such as plants are (1) coherent, orderly changes in spatial relations, and (11) coherent, orderly changes in the spectrum of metabolis activities, Microtubules have been implicated in a vide range af developmental and phyatological events where changes in spstial relattons occur. Consequently, we are seeking clues to the mechanising which govern the formation and disassembly of nicrotubules. The nitrogen and sutfur assinfletion pathways of plants converge at proteln synthesis, quantitatively the mafor fate of both nitrogen and sulfur. We therefore are studying regulation of the enaymes by which nitrate, armonta and urea are asgimflated, as well as the enzyues by vbich eulfate and organtc aulfur compounds are essimilated, wth the emphasis on charactertzation of Interconnections in the regulation of nitrogen and sulfur aestmilation.

\section{Microtubuleg and Tubulin}

\section{(a) Interaatione of Tobaaco Cell Components with Polmarizing Brain Tubutin}

P. Fflner, S. Hoeper

Although colchlcine binding protein can be extracted from cultured tobacco cells and was ghow to resemble animal tubulin In atmost all respects, attempts to Isolate thlcratubules from tobacco or other plant sources by methods which work with animal cells have falled. Also, attemp ts to cause tobacco tubulin to polymerfze into wicrotubules in crude extracts have fatled. Two poestble sources of difficulty have been explored: (1) an Inhibitor of polymerization or activator of depolymerization could exist in tobacco extracts, (11) the tubulin in tobacco extracts could be too dilute to polynerize (a critical concentratton has not been teached). We bave obtained evidence for the extstence of an Inhibitor of polywerization of bratn tubulin In tobacco extracts. The inhibitor appears to be titratable with brain tubulin. Addition of braln tubulin regults in polymerization proportional to protein concentration after a certain threghold is exceeded. By prelabeling the tobacco proteins with a radioactive amfno actd, it is posstble to ask if any tobacco protelos are selectively assoctated with the polymerizing brain tubulin. 
We have obtained indications of asgociation of tobacco protein with the polymerizing brain tubulin, but it remalne to be determined whether or not these tobacco protejas are tubulins.

(b) Charastarisation of the Reastion between Tubutin-Colchicine Complas and Nispotwbules

P. Filner, S. Hoeper

The binding reactlon between nicrotubules and tubuiln-colchicine cotmplex, which we discovered last year, has been found to resemble the polymertzation reaction of tubulin quite clogely. The najor difference is that there are a limited number of binding sites for tubulin-colchicIne conplex in a microtubule preparation. Concentrations of complex eufficient to approach saturation of the binding aftes do not prevent tubulin from polymertaing, nor do they cause massive depolymertzation of mitcratubules, at least in the pregence of glycerol, which stabilizes microtubules. We have proposed that the interaction of colchicine with microtubules proceeds in two steps: first, a binding of colchicine by free tubulin; gecond, a binding of tubulin-colchicine complex by wherotubules, the latter by a reaction which ia an analog of tubulin polynerization. It remains to be determined whether the binding of complex to macrotubulea has a quantitative influence on ufcrotubule depolymeriagtion or tubulin polymerization. The binding of radloactive complex to brain nicrotubules has proven to be a very conventent means of asgaying "polymertzatton" and effecta of factora on "polyaerization". This aseay is the firet one of whtch we are aware that has the potentlal for detecting microtubules and tubulin polymextzation in crude extracts in which the microtubutes are too dilute substantially to effect elther viscosity or light scattering, the two aseays most commonly used for polymerization of relatively pure brain tubulin.

(c) Nechonitm of Registanos of Colshicum to Cotohicine, an Alkatoit which It Symtherizes

N. Yadav, P. Filner

Colohioum autionate, the autumn crocus, talerates very high concentrations of exogenously applied colchicine, as well ag the high concentration of endogenously aynthesized colchicine. The mechanitu of resiatance to this alkaloid is of some theoretical interest since colchicine Interactg with a specific binding site of tubuling that has been highly 
conserved during evolution and is therefore thought to be an essential part of tubulin. Does Cotchicum have tubulin with a colchicine binding site or not? If ft lacks the binding site, then the site to not essential for the function of tubulin. If th possesses the binding site, how lo the colchfcine kept from the tubrilin?

A proteln fraction found in very high concentrations in lesves of colohioun autumale has asgoclated with it a chromophore that 1t tighty bound and closely resembles colchictne in tts spectral characteristica. The protein is composed of subunits of molecular welght close to 55,000 , as is tubulin from other sources. Current work 18 designed to determine If this Is a tubulin-11ke protein, or if it Is RUDP carboxylase, the most abundant protein in leaves, which also has a subunit of the observed stze.

A mejor difficulty in working with Colohioum autumale is the very brief natural period of vegetative growth, about six weeks. In order to have plant material all year long, we are attempting to accelerate and retard the onset of vegetative growth by varying the length of the cold treatment.

(d) Preparation of ${ }^{125}$ I Labeled Tubutin

H. Quader, P. Filner

There is a need for radioactive tubulin of high spectife activity so that the kinetics of tubulin polymerization and other tubulin interactions can be readily quantitated in the presence of other materfals. The only readily avallable source of polywerizable tubulin 1a mamalian or avian brain, but it is exceediggly difficult to obtain highly radioactive tubulin from brain via blological labeiting, 1.e. feeding of radioactive precursors. Therefore, we have been exploring chentcal labeling. Direct lodination with ${ }^{125} \mathrm{I}$, using ${ }^{125} \mathrm{I}-\mathrm{KI}$ and an oxddizing agent, Io unsatisfactory because the oxidizers and the lodine denature tubulin. golton and Hunter (1973) devised en indirect lodiratton procedure, uging ${ }^{125}$ I-todophenyIproptonyl-N-succlnimfde, which acetylates epsilon amino groups of lysine at neutral pH in aqueous solutlons. With this reagent, 1t was possible to prepare tubulin with one ${ }^{125}$ I per tubulin molecule. This tubulin would not polymer1ze. However, when only one ${ }^{125}$ I was bound per ca. 10 tubulins, the radioactive tubulin would polyoexize into microtubules. This finding indicates that the constraints on tubulin structure 
Impoged by the interactions which occur in microtubuleg are so great that the polymertzing propexty of the pratein 18 greatly nodifled by acetylation of a single antino group, and the microtubule can tolerate only about $I$ modified tubulin for every 10 in the microtubule.

Reference

Boltoo, A. E. and W. M. Hunter, Biachem. J. 133:529 (1973)

\section{Regulation of Nitrogen and SuIfur Assimilatton in Plente}

(a) Urea and Amonia Assimization in Tobaceo Cetls

T. Skokut, P. Filner, C. P. Wolk

Anmonia and uxea are the major nitrogenoug fertilizers currently used throughout the world. Syathesis of these compounds is a najor fraction of the energy Investment in Agriculture. It is ugually taken for Branted that these compounds are converted to nitrate by soll bacterfa before they are asginilated by plante. However, plante can assimilate these compounds directly. Very little 19 knowo about the direct assimilation of urea and ammonia by plants, espectally about how plants regulate these processes.

He have Initiated a study of the paths of ammonia and ures asafmilation and their regulation in cultured tobacco cells. The major findings to date are: (1) extracts of tobacco cells lack the enzyues of the urea-rallophanateandonla patbway, which ig tmportant in sone algae and fungt; tobacco cell extracts possess the enzyme urease, which is suffictent for the urea $+\mathrm{H}_{2} \mathrm{O}$. ammonia patinsy. Using ${ }^{13} \mathrm{~N}-\mathrm{NH}_{4}^{+}$, it has been found that ammonta is incorporated into glutanine by intact tobacco cells much more rapialy than Into glutamate. This finding is consistent with recent findings of others that point to glutanine rather than glutarste as the firot product of amonie asgimilation in plante.

Growth of tobacco cells on ammonia or urea is tnhtbited by nethylamine to a greater extent than growth on attrate. However, methylanine, which Is congldered an analog of ammonia, does not strongly tnhtbit ammonfa uptake, urease activicy or uresse development in the tobacco cella. Since the patkways of asolmilation of nitrate, amonila and urea sre considered to be Identical after the formation of ammonia, the methylamine effect to paradoxical. 
We belleve that the nethylanine effect merits closex exanination, oince It way be a mantfestation of different pathway or intracellular localizatione of ammonia agsinilation, depending on the nitrogen source.

(b) Seleation of Mutants of the Sulfus and Aitrogen Patroway in the Plant Kingdom

S. Flashman, P, FıIner

Results obtafaed earlier in this laboratory by Reuveny (1975) Buggested that it might be posstble to use selenate on plants in a manner analogous to the way to which penicillin 1s used on bacterta by genetictsta: to k1ll growing cells, whlle allowing non-growing nutant cells to survive. This geemed plausible because: (1) sulfur atarvation of cultured tobacco cella derepresses ATP sulfurylase, and presumably the rest of the autfate pathway; (1i) selenate, an anelog of aulfate, is very toxic to tobacco cells in which ATP sulfurylase to derepresged, but not to cells in which the enzywe is repressed; (iI) the enzywe cannot be decepressed in cells lacking an exogenous assintlatable nitrogen source. These observations led to the prediction that cella deprtved of a ntitrogen source would be protected against selenate toxiclty. This prediction hss been confirmed expertments11y. It seems 1tkely, therefore, that if the cells are "deprived" of nttrogen as a result of a genetic leston rather than a defiefency of the emvironment, such mutants afight also be protected agalnst selenate toxic1ty.

The minimal concentration of selenate and mintwal exposure tiwe necessary for killing close to $100 \%$ of tobacco cells with a nitrogen eupply but whlch perult aurvival in the absence of nitrogen, have been determined. Following the kflilng treatment, an antldote contalning a vartety of nitrogenous compounds 18 administered, In order for the hypothetlcal nutant survivors to grow.

The same selection scheme is being tested on Chtamydomonas retrhondtit and yeast. At the time of this writing, we do not get know ff the selection torks,

\section{Refereace}

Retrueny, Z., Ph.D. thesls, Michigan State UnIversity, 1975 


\section{MECHANISM OF SULFUR DIOXIDE TOXICITY IS PLANTS}

R. Bregsan, L, Wlison, P. Filner

As the world's oupplies of ofl and patural gas rapidly diminish and become depleted during the next three decades, It is expected that cosi will become the nafor anergy source for the U.S. Wuch of thts coal has a high oulfur content, and so a bubstantial increase in atmospherte $\mathrm{SO}_{2}$ poliution is anticipated. Although the concentrationg of $\mathrm{sO}_{2}$ at which plants suffer denage are known, netther the nechanism of toxicity, nor of realotance is undergtood. In reaponie to ERDA's need for infornation on the effects of $\mathrm{SO}_{2}$, we recently lnitiated a otudy of these machantams.

Wide variation in sensitivity to $\mathrm{SO}_{2}$ was evldent atong the cucurbite, In a survey done many years ago (Thonas 을 슥., 1950). Consequently, wo are concentrating on the cucurbite. We have found that the classic Bymtome of $\mathrm{s}_{2}$ toxictity can be elicited in detached leaven by exposing them to blautfite salt solutiong. The leaves respond when flosted on, vacuur Infiltrated with, or fed through the cut petiole with, bisulfite solutions. Using these techniques, we have confinmed the occurrence of a wde range of seneltivity in the cucurbita, and have found the range of aenaltivity among cultivars of Cucubita pepo (aquesh) to be particularly strik1ng.

Quantitation of $\mathrm{SO}_{2}$ injury has traditional1y been done by making subjective Judgements of the appearance of damaged leaves. We are seeklng an objective quantitative method. The decrease in chlorophyll content vag found to be a poor Indicator of leaf injury, because the magnttude of the change was snall. Ethylene production 1ncreases greatly in silightly infured leaves, but declines in severely Injured leaves. The ethylene production response correlates with sensitivity to $\mathrm{SO}_{2}$ among cucurbits. Therefore, ethylene production may be a useful Indicator of injury by $\mathrm{SO}_{2}$.

An apparatus for exposing plants to atmogpheres of defined $\mathrm{SO}_{2}$ concentration, for messuring $\mathrm{so}_{2}$ absorption by the plants, and for masaturing emisetion of gaseous oulfur compounds by plants, is under congtruction. A Bystem for analyeite of ${ }^{35} \mathrm{~S}$-labeled sulfur compounds formed from ${ }^{35} \mathrm{~S}^{-\mathrm{SO}_{2}}$ 1s 
betng developed. Comparisons of the metabolle fatea of $\mathrm{SO}_{2}$ In resiatant and sensitive planta are planmed.

\section{Reference}

Thomas, H. D., R. H. Flendrlckg and G. R. H111, Ind, Eng, Chept. 42:2231 (1950) 
AUTHOR TNDEX FOR RESEARCH REPORTS

(In parenthesia, auperviaing faculty member)

Austin, S. (H.s.U, Cyclotron) ................... 76 Bell, D. (M.S.U. Departnent of Botany and Plant Pathology) . . . 108 Beutelmann, P. (H. Kende) . . . . . . . . . . . . . . . 62 Bregsan, R. (F. F1lner) . . . . . . . . . . . . . . 128 Cardemil de Balboa, L. (P. Wolk) . . . . . . . . . . . 79 Caughey, X. (D.T.A. Lamport) ............... 82, 86, 87 Cetas, C. (J,A.D. Zeevaart) , ............. 50,52,53 Delnes, D. P. ......... . . . 94, 96, 99, 100, 103, 119 deZacks, R. (H. Kende) . . . . . . . . . . . . 65,70 Dittrich, P. (Untveratty of Mulch, Germany) ...... . 36, 38, 40 Dubbe, D. (K. Rnschke) . . . . . . . . . . . . . . . 32 Er1ceon, H. C. (D. P. Delmer) ................. 103 Farquhar, G: D. (K. Ragchke) . . . . . . . . . 28, 29, 32 Fllner, P. ............ 114, 123, $124,125,126,127,128$ Plgher, R. H. (C. P. Wolk) .................... 74 Flashman, S. (P. Filner) ..................... 127 Galonsky, A. (M.S.t. Cyclotron) . . . . . . . . . . . . 76 Gaxdnex, G. (H. Kende) ..................... 68, 70 Good, H. E. (K.S.U. Department of Botany and Plant Pathology) . . 108 Hangon, A, D. (H. Kende) ................. 56, 57,60 Haug, ........................ 106, 107, 108 Heintger, U. (D. F. Delmer) . . . . . . . . . . . . . . . 96 Hrogawa, T. (C. P. Wolk) ... . . . . . . . . . . . . . . 74 
Hoeper, S, (P, Fllner) . . . . . . . . . . . . . . . 123, 124

Hatmg, J.-C. (A. Haug) . . . . . . . . . . . . . . . . . . 106

Rende, H. . . . . . . . . . . 56,57,60,62,64, 65, 68, 70

Knlow, C. (D. P. Delmer) . . . . . . . . . . . . . . . 96, 99

Lamport, D. T. A. .............. 82, 83, 84, 86, 87, 88, 90

Lang, A. . . . . . . . . . . . . . . . . . . . . 43 43

Leonerde, X. (A, Haug) . . . . . . . . . . . . . . . 108, 119

Yamabe, X. (K. Poff) ........................ 111, 113

Keaks, J. (C. P. Wolk) . . . . . . . . . . . . . . . . 76

Meinert, K. (D. P. Delmer) . . . . . . . . . . 94, 99, 100

Wort, A. (D.T.A. Lamport) . . . . . . . . 83, 84, 86, 88, 90

Nordln, P. (D.T.A. Lamport) . . . . . . . . . . . . . . . 88

Phtllips, D. (K. Raschke) . . . . . . . . . . . . . . 28

Poff, .. ................... 111, 113, 114, 119, 120

Quader, H. (P. Filner) . . . . . . . . . . . . . . . . 125

Raschke, K. ................... 28, 32, 34, 36, 38

Rodaway, S. (H. Kende) . . . . . . . . . . . . . . . 70

Schmldt, н. (K. Poff) ...................... 114, 116

Shaffer, P. พ. (C. P. Wolk) . . . . . . . . . . . . . . . . . 74

Sharkey, T. D. (K. Raschke) . . . . . . . . . . . . . 28, 34

skokut, H. (x. Poff) ........................... 120

Skokut, T. (P. Filner) . . . . . . . . . . . . . . 96, 126

Susgman, M. R. (H. Kerde) . . . . . . . ......... 65, 68

Suttle, J. (K, Kende) . . . . . . . . . . . . . . . 51, 64

Thomas, J. (C. F. Wolk) ..... . . . . . . . . . . . 76

Van Rompuy, L. L. L. (J.A.D. Zeevaart) . . . . . . . . . . . . . 47 
Weller, в. (A. Haug) . . . . . . . . . . . 107 Whttaker, B. (k, Poff) ................... 119 Wlson, . ...................... 128 Wolk, c. P. ................ 74, 76,79, 126 Yadav, א. (P. Filner) .................. 124 Yang, 1. L. (A. Haug) ................. 107 Zeevaert, J. A. D. ............. 47, 50, 51, 52, 53 